\title{
Hemocompatibility during extracorporeal circulation for cardiopulmonary bypass
}

Citation for published version (APA):

Weerwind, P. W. (2003). Hemocompatibility during extracorporeal circulation for cardiopulmonary bypass. [Doctoral Thesis, Maastricht University]. Datawyse / Universitaire Pers Maastricht. https://doi.org/10.26481/dis.20030924pw

Document status and date:

Published: 01/01/2003

DOI:

10.26481/dis.20030924pw

Document Version:

Publisher's PDF, also known as Version of record

\section{Please check the document version of this publication:}

- A submitted manuscript is the version of the article upon submission and before peer-review. There can be important differences between the submitted version and the official published version of record.

People interested in the research are advised to contact the author for the final version of the publication, or visit the DOI to the publisher's website.

- The final author version and the galley proof are versions of the publication after peer review.

- The final published version features the final layout of the paper including the volume, issue and page numbers.

Link to publication

\footnotetext{
General rights rights.

- You may freely distribute the URL identifying the publication in the public portal. please follow below link for the End User Agreement:

www.umlib.nl/taverne-license

Take down policy

If you believe that this document breaches copyright please contact us at:

repository@maastrichtuniversity.nl

providing details and we will investigate your claim.
}

Copyright and moral rights for the publications made accessible in the public portal are retained by the authors and/or other copyright owners and it is a condition of accessing publications that users recognise and abide by the legal requirements associated with these

- Users may download and print one copy of any publication from the public portal for the purpose of private study or research.

- You may not further distribute the material or use it for any profit-making activity or commercial gain

If the publication is distributed under the terms of Article $25 \mathrm{fa}$ of the Dutch Copyright Act, indicated by the "Taverne" license above, 
Hemocompatibility during extracorporeal circulation for cardiopulmonary bypass 
(C) Patrick W. Weerwind, Nijmegen 2003 ISBN 90-5278-386-1

Omslagillustratie: Katja Loesch, Datawyse Vormgeving en druk: Datawyse / Universitaire Pers Maastricht 


\title{
HEMOCOMPATIBILITY during extracorporeal circulation for cardiopulmonary bypass
}

\author{
PROEFSCHRIFT
}

ter verkrijging van de graad van doctor aan de Universiteit Maastricht, op gezag van de Rector Magnificus, Prof. dr. A.C. Nieuwenhuijzen Kruseman, volgens het besluit van het College van Decanen, in het openbaar te verdedigen op woensdag 24 september 2003 om 16.00 uur

door

PATRICK WENDEL WEERWIND geboren op 21 november 1964 te Curaçao, Nederlandse Antillen

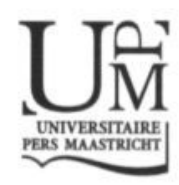




\section{Promotor}

Prof. dr. B. Mochtar

Co-promotores

Dr. T. Lindhout

Dhr. D.S. de Jong, CCP

\section{Beoordelingscommissie}

Prof. dr. M.J.H.M. Jacobs (voorzitter)

Prof. dr. M.H.J. Brouwer (Universitair Medisch Centrum Nijmegen)

Prof. dr. H. ten Cate

Prof. dr. B.E. de Pauw (Universitair Medisch Centrum Nijmegen)

Prof. dr. J. Rosing

Financial support by Cardio Research St. Radboud for publication of this thesis is gratefully acknowledged. Additional support granted by AB \& TD BV, Datascope BV, Fresenius HemoCare, Heart Medical Europe BV, Jostra Nederland BV, Krijnen Medical, Laguna Health BV, Sorin Biomedica Nederland NV, Terumo Europe NV, and Tyco Healthcare Nederland BV is appreciated. 
Aan mijn ouders

Voor Joke, Kevin en Trevor 



\section{CONTENTS}

List of abbreviations

CHAPTER 1 | General introduction

CHAPTER 2 | Clinical evaluation of Duraflo II heparin-treated extracorporeal circuits on the activation of the kinin and coagulation system

CHAPTER 3 Influence of Duraflo II heparin-treated extracorporeal circuits on the systemic inflammatory response in patients having coronary bypass

CHAPTER 4 Ex vivo testing of heparin-coated extracorporeal circuits: bovine experiments

CHAPTER 5 | Exposure of procoagulant phospholipids at the surface of platelets in patients undergoing cardiopulmonary bypass using non-coated and heparin-coated extracorporeal circuits

CHAPTER 6 | Thrombin generation during cardiopulmonary bypass: the possible role of retransfusion of blood aspirated from the surgical field

CHAPTER 7 | General discussion

CHAPTER 8 | Summary

CHAPTER 9 | Samenvatting

CHAPTER 10 | References

Dankwoord 


\section{List of abbreviations}

ACD acid-citrate-dextrose

ACT activated coagulation time

CABG coronary artery bypass grafting

CBAS carmeda bioactive surface

$\mathrm{CPB} \quad$ cardiopulmonary bypass

EDTA ethylenediaminetetraacetic acid

ELISA enzyme-linked immunosorbent assay

$\mathrm{F} 1+2$ prothrombin fragment $1+2$

FITC fluorescein isothiocyanate

FPA fibrinopeptide A

ICAM-1 intercellular adhesion molecule-1

IL-1 interleukin-1

IL-6 interleukin-6

IL-8 interleukin-8

PAP plasmin- $\alpha_{2}$-antiplasmin

PPP platelet procoagulant potential

PS phosphatidylserine

RIA radio immuno assay

s soluble

SEM standard error of the mean

sTNF-R55 soluble tumor necrosis factor-receptor 55

sTNF-R75 soluble tumor necrosis factor-receptor 75

TNF- $\alpha \quad$ tumor necrosis factor- $\alpha$

TAT thrombin-antithrombin

TF tissue factor

TFPI tissue factor pathway inhibitor 


\section{CHAPTER 1}

\section{General introduction}

"The future holds much promise. As the biochemistry of the multiple reactions that occur when blood contacts foreign surfaces becomes clearer...

... it offers more immediate benefits for the control of the thrombotic, bleeding, and inflammatory complications associated with CPB and open heart surgery"

(L.H. Jr. Edmunds: Blood-surface interactions during cardiopulmonary bypass.

J Card Surg 1993;8:404-410.) 
Cardiopulmonary bypass (CPB) is a method of artificial whole body perfusion in which the function of the heart and lungs is replaced by an extracorporeal circuit consisting of an artificial lung, blood pumps, and other associated devices. The use of $\mathrm{CPB}$ provides a controlled environment for surgery of the heart and great vessels, but $\mathrm{CPB}$ is also used for medical treatment in other areas. Since the introduction of CPB for cardiac surgery, by Gibbon in 1954 [1], important technical improvements were made in design and application of materials used in the extracorporeal circuit. These modifications have led CPB to be considered as a safe part of surgical and other medical therapies nowadays. However, the systemic inflammatory response that includes generation of humoral mediators, cellular activation, and impaired hemostasis, which all can contribute to cerebral injury and organ dysfunction is thereby still a major drawback. The systemic inflammatory response after $\mathrm{CPB}$ is a moderate sepsis-like reaction, but when the $\mathrm{CPB}$ procedure is prolonged, the patients are either very old or very young, patients have a preoperative history of congestive heart failure or myocardial infarctions, the risk of postoperative morbidity and mortality increases [2,3]. In the studies described in this thesis, we focused on the more homogeneous group of low risk patients undergoing elective coronary artery bypass grafting and/or valve surgery who show a relative mild clinical response, but still need intensive care treatment after the procedure. The objective of this thesis was to elucidate the hemocompatibility of extracorporeal circuits, with the intention of characterizing the performance benefits of heparin-treated circuits.

\section{BLOOD-FOREIGN SURFACE INTERACTION}

The deleterious effects associated with open-heart surgery have been attributed to various aspects of hemo-incompatibility of $\mathrm{CPB}$. In this respect, the contact of blood with the extracorporeal circuit during $\mathrm{CPB}$ has been implicated as the primary source of blood activation that inevitably leads to activation of blood related processes [4-12], which can be harmful for the patient by jeopardizing his morbidity during recovery of his surgical treatment. When blood circulates within the vascular system, it is in contact with a continuous luminal endothelial cell layer that is capable of producing, secreting, and binding both anticoagulants and procoagulants to maintain blood fluidity and vascular integrity. When blood leaves the endothelialized vascular system and enters into the extracorporeal CPB circuit, it is immediately exposed to the artificial surfaces of oxygenator, reservoirs, filters, tubing, as well as to other non-physiological conditions. An outline of activating pathways, which play an important role in the thrombogenicity and systemic inflammatory response after interaction of blood with the extracorporeal circuit, is schematically shown in figure 1 . In contact with blood, 


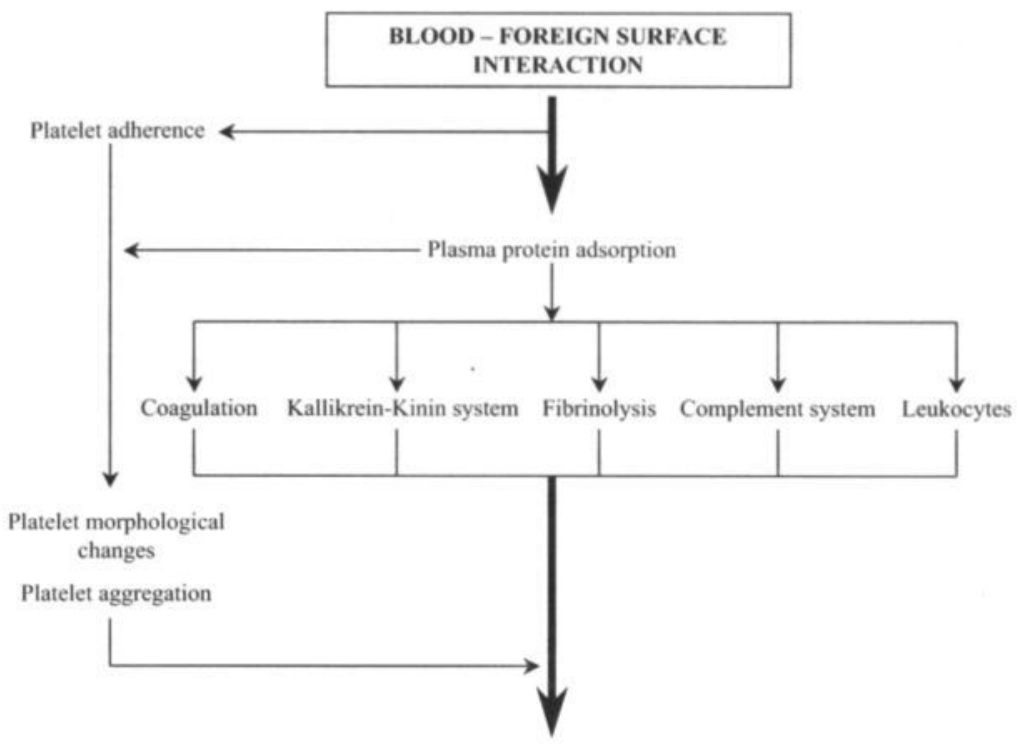

SYSTEMIC INFLAMMATORY RESPONSE

Figure 1 Sequences of events during the interaction of blood with materials.

most biomaterials become rapidly covered with a layer of proteins [7,13-17]. Some of the adsorbed plasma proteins become activated and initiate coagulation $[7,18]$. Eventually, the initiation of the coagulation system leads to thrombin formation. Moreover, several plasmatic systems like the kallikrein-kinin, complement, and the fibrinolytic system become activated [7,19]. Also the initial protein layer may comprise proteins that induce adhesion and activation of blood cells (leukocytes and platelets) [7,20-22]. Furthermore, these systems produce a stimulus that causes endothelial cell activation. Endothelial cell activation tips the balance of endothelial-derived factors to disrupt barrier function separating blood from tissues and enhances vasoconstriction, coagulation, leukocyte adhesion, and smooth cell proliferation $[7,23]$. Thus, these systems have the capacity to cross-activate one another and act in concert.

\section{SYSTEMIC ANTICOAGULATION THERAPY}

The most commonly used anticoagulant drug during CPB is heparin, which counterbalances the inherently thrombogenic nature of the devices' blood contacting surfaces. The major function of systemic heparin is the inhibition of thrombin and factor Xa by antithrombin. However, the thrombotic stimulus is 
only partially suppressed by high dosages of heparin [24-26]. Moreover, antithrombotic therapy is not always possible, e.g. in patients with a heparin-induced thrombocytopenia [27]. In addition, long-term contact with the surface of devices like ventricular assist devices and other extracorporeal life support systems could induce an additional set of problems (e.g. disseminated intravascular coagulation) related to impaired hemostasis and systemic inflammatory response [6,25,28-33]. The amount of the systemic anticoagulant should therefore be as low as possible, but still high enough to prevent significant thrombogenesis. The complex nature of the systemic inflammatory response has however not allowed, until now, the use of a single strategy to minimize the response.

\section{HEPARIN-TREATED CIRCUITS}

Because the exposure of blood to synthetic surfaces has been considered as the primary cause of blood activation, numerous attempts have been made to improve the hemocompatibility and to reduce $\mathrm{CPB}$-related complications. Unfortunately, most of the common interventions used to reduce the systemic inflammatory and thrombogenic responses, are merely attempts to palliate, rather than prevent, the underlying pathophysiology. Some of these attempts include pharmacological intervention (corticosteroids, protease inhibitors, antifibrinolytics, complement inhibitors), and extracorporeal blood purification (leukocyte-depletion, hemofiltration, cell-saving techniques), which treat the response after it has occurred. It would be preferential to temper the systemic inflammatory response using preventive measures. Obviously, there is a continuing quest for hemocompatible and non-thrombogenic materials. The general term "hemocompatibility" refers to those properties that allow CPB circuits to maintain contact with flowing blood without causing any adverse reactions, without releasing any leachable components, and without suffering any alteration. It was recognized relatively early that an improvement in the hemocompatibility of the materials used in $\mathrm{CPB}$ could significantly contribute to reduce extreme reactions. The attempt to coat the artificial surfaces with heparin, which imitates the antithrombogenic effects of heparansulfate at the endothelium, illustrates a promising approach in diminishing the harmful effects of devices to the patients' homeostasis [34-44]. Moreover, several commercially available types of heparin coatings were originally introduced to enable reduction or even elimination of systemic heparinization [45]. Later, it was found that modification of surfaces with heparin reduced complement activation by inhibiting C3-convertase $[34,41,46-48]$ and might thus bear the potential to change leukocyte activation and subsequently the leukocyte-endothelium interaction 
$[42,49]$. In a subsequent clinical study focusing on the mechanism, it was shown that reduced leukocyte activation during the use of heparin-coated CPB circuits, was a result of lower systemic heparinization [50].

The issue of whether full dose or lower dose heparin should be administered with heparin-treated circuits, however, is still a matter of debate. Several clinical studies have shown that heparin-treated circuits combined with reduced systemic heparinization can be safely used during coronary artery bypass procedures, because no significant increase in thrombin formation was observed in low dose $(100 \mathrm{IU} / \mathrm{kg})$ treated patients compared to high dose $(400 \mathrm{IU} / \mathrm{kg})$ treated patients [51,52]. In contrast, Despotis et al. [53] demonstrated that thrombin formation was better suppressed by higher heparin concentrations, which were also associated with significantly reduced blood loss. Other investigators reported that independent of the heparin dose ( $150 \mathrm{IU} / \mathrm{kg}$ versus $300 \mathrm{IU} / \mathrm{kg}$ ), thrombin formation, fibrin formation and fibrinolysis was increased in patients undergoing surgery with the use of heparin-coated CPB circuits [54,55]. None of these reports, however, has shown a reduction in postoperative bleeding using a low dose heparin management, one of the purported goals of reducing heparin doses. Thus, since heparin-treated circuits do not reduce thrombin formation during clinical CPB $[11,56]$, the use of low dose heparin is not associated with any advantage and does not seem justified. Furthermore, since subclinical coagulation activity exists during $\mathrm{CPB}$ and does not correlate with systemic heparin concentrations [25], it might be reasoned that this could be a consequence of the peculiar blood activation in the pericardial cavity. Even if anticoagulation is sufficient in the CPB system, it is not necessarily sufficient for blood in the thoracic cavities.

The use of heparin-treated circuits has also been associated with reduced postperfusion lung dysfunction in patients undergoing myocardial revascularization [57]. In spite of this observation, a clear benefit in the clinical outcome has not always been demonstrated [58]. Partly, the discrepancies may be attributable to different strategies regarding material-independent factors such as aspiration and return of shed pericardial blood into the systemic circulation during $\mathrm{CPB}$, and the use of an open or closed venous reservoir. On the other hand, also the lack of sufficient statistical power is a major handicap of most clinical studies, suggesting that the predisposition and perhaps the specific mechanisms of the systemic response to $\mathrm{CPB}$ may vary between patients. Consequently, the inhomogenicity of patients within clinical studies may complicate the interpretation of these data. However, recognizing that both biomaterial-dependent and -independent factors contribute to blood activation during $\mathrm{CPB}$, several changes may be required in the way $\mathrm{CPB}$ is performed in order to achieve clinical benefit from the use of heparin-treated extracorporeal circuits. Nevertheless, better clinical outcomes, with shorter lengths of stay in the intensive care unit and the hospital, and less respiratory and renal dysfunction were observed in a recent large multicenter ran- 
domized trial with high-risk patients undergoing surgery with the use of heparin-treated CPB circuits [59].

\section{MATERIAL-INDEPENDENT BLOOD ACTIVATION}

As discussed, the clinical benefits of surface modified extracorporeal systems on blood activation during CPB is more difficult to elucidate, since many factors independent of the blood-material interaction contribute to blood activation. Surgical trauma, including surgery related emboli, myocardial and pulmonary reperfusion injury upon release of the aortic crossclamp [60-63], direct blood-air interface [64], altered flow dynamics, the rate of hypothermia [65-68], and the formation of heparin-protamine complexes at discontinuation of CPB [69-71] have shown to be other sources of blood activation. Another major material-independent pathway is the deleterious influence of directly retransfused blood aspirated from the thoracic cavities into the systemic circulation during $\mathrm{CPB}$ [72-77]. The need to conserve red cells and minimize the transfusion of blood products has led to the use of blood aspirated from the surgical field [78]. However, this blood can contain as a result of surgical trauma, tissue-type plasminogen activator [79], tissue factor (TF) [73], mediastinal debris (primarily fat emboli) [80], and cell-derived microparticles [81] which are present in the mediastinal and pleural cavities. Interaction of blood with these procoagulant components may result in activation of the coagulation, platelet activation, and release of proinflammatory cytokines [73,75,80-87]. Therefore, retransfusion of blood aspirated from the thoracic cavities into the systemic circulation during $\mathrm{CPB}$ has shown to activate the coagulation cascade $[72-77,88]$, and to contribute to the generation of hemolysis $[72,89,90]$. Moreover, hemodynamic changes were also documented [91]. A possible explanation for the high activation marker levels in the blood aspirated from the thoracic cavities might be poor local anticoagulation. It has been reported that pericardial blood had lower levels of heparin than corresponding perfusate blood samples, and the levels of heparin in samples from the thoracic cavities correlated inversely with those of thrombin generation markers and factor VIIa [75]. Therefore, additional local anticoagulation seems required.

Removal of activated humoral and cellular components from shed mediastinal blood through a cell salvage system before returning it to the systemic circulation or totally discarding this blood, have shown to minimize delayed coagulopathy $[76,77]$. However, blood processing through a cell salvage system is not always possible, for example when exceptionally rapid and heavy bleeding is encountered. An alternative approach, therefore, could be to add neutralizing tissue factor antibodies or tissue factor pathway inhibitor (TFPI) directly to blood aspi- 
rated from the thoracic cavities during CPB [73]. Anyway, if the hemocompatibility of extracorporeal circuits becomes better, the discrepancy in thrombogenicity between an extracorporeal circuit and tissue will become larger. To manage this discrepancy, it may be preferable to use specific anticoagulant agents in both mediastinal and pleural cavities to maintain sufficient local anticoagulation. However, great diligence is required to distinguish the latter entities from purely material-associated problems, thus avoiding a biased view on the outcome of patients treated with the use of $\mathrm{CPB}$. In addition, the sometimes assumed deleterious effects of CPB does not seem to be increased by the length of time and duration of the $\mathrm{CPB}$ in a closed circuit as used for long-term extracorporeal membrane oxygenation treatment fot temporary respiratory dysfunction.

\section{OUTLINE OF THE THESIS}

The pathophysiology of CPB can be considered complex and multifactorial. Consequently, the investigation of the underlying mechanisms needs a multiparameter approach. The objective of this thesis was to elucidate the hemocompatibility of extracorporeal circuits, with the intention of characterizing the performance benefits of heparin-treated circuits. For that purpose, the following questions were formulated:

- Do heparin-treated extracorporeal circuits inhibit the activation of the kinin and the coagulation system during clinical cardiopulmonary bypass and, hence, alter the postoperative patient outcome? (Chapter 2).

- Will cardiopulmonary bypass with heparin-treated extracorporeal circuits lead to a reduction in the leukocyte-mediated inflammatory response in patients undergoing elective coronary artery bypass grafting? (Chapter 3 ).

- During long-term ex vivo extracorporeal support without full systemic heparinization and with minimal interference of the so-called biomaterialindependent stimuli, is the heparin-treated surface thromboresistant? (Chapter 4).

- Do different kinds of extracorporeal circuits during cardiopulmonary bypass lead to a varying degree of platelet procoagulant activity? (Chapter 5).

- If the blood aspirated from the surgical field is returned to the systemic circulation during routine cardiopulmonary bypass, what is the effect on systemic TF-driven thrombin generation? (Chapter 6). 



\section{CHAPTER 2}

\section{Clinical evaluation of Duraflo II heparin-treated extracorporeal circuits on the activation of the kinin and coagulation system}

P.W. Weerwind ${ }^{1}$, C.P.M. Reutelingsperger ${ }^{2}$, T. Lindhout ${ }^{2}$, K. Hamulyák ${ }^{3}$, A. Schauwaert ${ }^{3}$, D.S. de Jong ${ }^{1}$, H.C. Hemker ${ }^{2}$, O.C.K.M. Penn ${ }^{1}$.

${ }^{1}$ Department of Cardiothoracic Surgery / Extracorporeal Circulation, University Hospital Maastricht, ${ }^{2}$ Department of Biochemistry, Maastricht University, ${ }^{3}$ Department of Hematology, University Hospital Maastricht, The Netherlands.

Proc Am Acad Cardiovasc Perfusion 1994;15:62-69.

Presented at the $15^{\text {th }}$ Annual seminar of the American Academy of Cardiovascular Perfusion, New Orleans, USA, January 28-31, 1994. 


\section{ABSTRACT}

Objective. This study investigates the thrombogenicity of Duraflo II heparin-treated extracorporeal circuits during routine cardiopulmonary bypass (CPB) procedures compared to routinely used non-coated circuits.

Methods. Blood samples taken from 20 adult patients undergoing elective myocardial revascularization were assayed for kallikrein- $\mathrm{C}_{1}$-inhibitor complexes, plasma prothrombin fragment $1+2$ complexes, thrombin-antithrombin, plasmin- $\alpha_{2}$-antiplasmin complexes, and procoagulant activity of platelets. The patients were randomly divided into two groups with (Duraflo II, A, n=10) or without (Control, $\mathrm{B}, \mathrm{n}=10$ ) the use of a heparin-treated extracorporeal circuit. After CPB scanning electron micrographs were made of some arterial line filters. Furthermore, the blood loss within the initial 24 hours after surgery, and the clinical recovery were also monitored.

Results. The initiation of the blood coagulation process as well as the kinin system was hardly activated by the interaction of blood with both extracorporeal circuits. The extent of thrombin generation and inhibition increased with time on CPB, but did not differ between the two circuits. Furthermore, thrombin generation and fibrinolysis increased following the neutralization of the heparin with protamine chloride. Twenty-four hours after surgery the thrombin generation and inhibition showed to be significantly higher when a heparin treated circuit was used. During CPB no significant difference in procoagulant phospholipids activity of platelets was detected. However, 24 hours after surgery the excitability of the procoagulant phospholipids activity was significantly higher when a heparin treated circuit was used. Scanning electron micrographs of the arterial line filters showed more adhesion and pseudopod formation of platelets on the heparin treated filters. Furthermore, there existed no significant difference between the two groups regarding the blood loss within the initial 24 hours after surgery and the clinical outcome in terms of the duration on intensive care unit and the duration of hospital stay.

Conclusion. Based on our results an advantage of using Duraflo II heparin treated extracorporeal circuits during routine $\mathrm{CPB}$ procedures could not be confirmed. 


\section{INTRODUCTION}

Cardiopulmonary bypass (CPB) for open-heart surgery is associated with bleeding complications, which have been related to systemic heparinization and trombocytopathia/thrombocytopenia, fibrinolytic disorders and inflammatory response $[27,78,92-94]$. The contact between blood and materials induces the activation of blood related biological processes, which can be harmful for the patient by jeopardizing his morbidity during recovery of his surgical treatment. Several investigators are claiming that clinical complications during and after extracorporeal circulation attributed to the inflammatory response and bleeding disorders could be considerably reduced with heparin-treated extracorporeal circuits $[35,93,95-99]$. It also has been reported that both platelet count and platelet functions could be preserved during $\mathrm{CPB}$ when the circuit was treated with heparin $[29,97,98,100]$. Although a variety of test and testsystems have been used to examine the effects of coated systems, it is still unknown to what extent coating prevents impairment of hemostasis during CPB [101]. When blood comes into contact with foreign material, activation of the coagulation system, blood cells (platelets and leukocytes), and the complement system have to be closely monitored.

In the present study we investigated the inhibiting effects of Duraflo II heparin-treated extracorporeal circuits on the activation of the kinin and coagulation system during $\mathrm{CPB}$ compared to routinely used non-coated circuits, with the intend of characterizing the performance benefits of these heparin-treated systems.

\section{PATIENTS AND METHODS}

\section{Patients}

Twenty adult patients undergoing elective myocardial revascularization were enrolled in this study. The patients were randomly divided into two groups with (Duraflo II, A, n=10) or without (Control, B, n=10) the use of a heparin-treated extracorporeal circuit. Exclusion criteria were the following: previous cardiac surgery, congestive cardiac failure, neurological disorders (e.g. cerebrovascular accident), severe pulmonary disorders (e.g. chronic obstructive pulmonary disease, emphysema), insulin dependent diabetics, renal diseases (e.g. renal failure), liver diseases and pre-operative coagulopathies. No significant difference existed between the two groups as related to sex, age, bodyweight, height, as well as CPB time and aortic crossclamp time (Table 1). Informed consent was obtained from each patient the day before the operation. 
Table 1 Clinical data of the Duraflo II group and control group. The values are expressed in mean \pm standard deviation. There existed no significant difference between the two groups. Duraflo II (group A) Control (group B)

No.

Sex M/F

Age (years)

Height $(\mathrm{cm})$

Weight $(\mathrm{kg})$

Perfusion time (min)

Aorta occlusion time ( $\mathrm{min})$
10

$9 / 1$

$58 \pm 12$

$176 \pm 9$

$86 \pm 14$

$82 \pm 24$

$51 \pm 18$
10

$8 / 2$

$66 \pm 11$

$173 \pm 9$

$78 \pm 10$

$83 \pm 21$

$54 \pm 12$

\section{Anesthesia and monitoring}

Standard anesthetic (lorazepam, fentanyl citrate, sufentanil citrate, alfentanil hydrochloride, midazolam hydrochloride, pancuronium bromide) and monitoring techniques (electrocardiogram, central venous/pulmonary and arterial pressure monitoring, urinary output, rectal and skin temperature monitoring) were used in both groups. Cefuroxim was used for antibiotic treatment, and the first dose was administered before sternotomy.

Before connection of the extracorporeal circuit for CPB, heparin (300 IU/kg, Heparin Leo, Leo Pharmaceutical Products BV, Weesp, The Netherlands) was administered in order to achieve an activated coagulation time (ACT) $>480 \mathrm{sec}-$ onds (Hemochron 400, International Technidyne Corp., New Jersey, USA).

\section{Cardiopulmonary bypass}

The extracorporeal circuit consisted of the components listed in Table 2. In group A, all components exposed to blood were pretreated with heparin-bonded coating (Duraflo ${ }^{\circ}$ II, Bentley/Baxter Inc., Irvine, CA, USA). The circuit in group $\mathrm{B}$ consisted the components of our routinely used (basic) extracorporeal circuit. The standard priming of our extracorporeal circuit was $1300 \mathrm{ml}$ Haemaccel $3.5 \%$ (Behringwerke AG, Marburg, Germany), $200 \mathrm{ml}$ Mannitol 20\%, $100 \mathrm{ml}$ H-Albumin 20\%, $50 \mathrm{ml} \mathrm{NaHCO} 38.4 \%, 20 \mathrm{ml} \mathrm{KCl} \mathrm{7.45 \%} \mathrm{(B.Braun} \mathrm{Medica}$ BV, Uden, The Netherlands) and 6500 IE Heparin Leo. In three cases it was necessary to substitute part of the haemaccel by packed red cells (two times in group $\mathrm{B}$ and one time in group $\mathrm{A}$ ), to prevent the hematocrit to drop below $20 \%$ during $\mathrm{CPB}$.

After institution of cardiopulmonary bypass at a flow rate of $2.4 \mathrm{~L} / \mathrm{min} / \mathrm{m}^{2}$, and after reaching a blood temperature below $28^{\circ} \mathrm{C}\left(25-28^{\circ} \mathrm{C}\right)$, the heart was topically cooled till fibrillation using cold saline $0.9 \%$ at $4^{\circ} \mathrm{C}$. The aorta was then 
Table 2 Components of the extracorporeal circuits

Duraflo II heparin treated circuit * Control circuit (group A)

\begin{tabular}{|c|c|c|}
\hline Arterial line filter & AF 1040 Gold & Sartorius ** \\
\hline $\begin{array}{l}\text { Hollow fiber membrane } \\
\text { oxygenator }\end{array}$ & Univox Gold & Univox * \\
\hline Venous reservoir & BMR-1900 Gold & BMR-1900* \\
\hline Cardiotomy reservoir & BCR-3500 Gold & William Harvey H4700 (Bard) \\
\hline Pump tubing & $\begin{array}{l}\text { Silastic Down Corning Medical } \\
\text { grade }\end{array}$ & $\begin{array}{l}\text { Silastic Down } \\
\text { Corning Medical grade }\end{array}$ \\
\hline Arterial-venous tubing & $\begin{array}{l}\text { Bentley bypass } 70^{\circ} \\
\text { tubing class VI }\end{array}$ & Tygon S 50 HL class VI \\
\hline Cardiotomy tubing & $\begin{array}{l}\text { Bentley bypass } 70^{\circ} \\
\text { tubing class VI }\end{array}$ & $\begin{array}{l}\text { Tygon S } 50 \text { HL class VI and } \\
\text { Silastic Down Corning Medical grade }\end{array}$ \\
\hline Arterial cannula & ARL-24 Fr (Research Medical, Inc) & ASR-24 Fr $* *$ \\
\hline Venous cannula & $\begin{array}{l}\text { Dual drainage venous return } \\
\text { catheter TR } 3651 \mathrm{~B} \\
\text { (Research Medical, Inc) }\end{array}$ & $\begin{array}{l}\text { Dual drainage venous return } \\
\text { catheter TR } 3651 \mathrm{~B} \\
\text { (Research Medical, Inc) }\end{array}$ \\
\hline
\end{tabular}

crossclamped and a single dose of approximate $800 \mathrm{ml}(600-1000 \mathrm{ml})$ of St. Thomas I cardioplegic solution at $4^{\circ} \mathrm{C}$ was infused into the aortic root in a period of 4 minutes (3-5 minutes) to provide myocardial preservation. Topic cooling was maintained during the infusion of the cardioplegic solution. Target flow rates of $2.4 \mathrm{~L} / \mathrm{min} / \mathrm{m}^{2}$ were maintained at normothermia and correspondingly lower rates of $2.0 \mathrm{~L} / \mathrm{min} / \mathrm{m}^{2}\left(1.8-2.2 \mathrm{~L} / \mathrm{min} / \mathrm{m}^{2}\right)$ were maintained at moderate hypothermia of $28^{\circ} \mathrm{C}$, depending on the venous oxygen saturation and the arterial pressure. Pulsatile perfusion was used throughout the period of aorta crossclamping. During the conduct of $\mathrm{CPB}$ attention was given to restrict, and if possible, to avoid the use of the cardiotomy suction. The cardiotomy suction and aortic root venting were in all cases less than $2 \%$ of the calculated flow $(<90$ $\mathrm{ml} / \mathrm{min}$, intermittent), using a volume pressure control unit with negative pressures less than $60 \mathrm{mmHg}$. After completion of all the distal anastomoses, the aortic crossclamp was removed and the proximal anastomose was performed with a partial occlusion clamp after spontaneous or electrical defibrillation, while the rewarming of the patient to $37^{\circ} \mathrm{C}$ continued.

Additional heparin was administered during bypass if the ACT was lower than 400 seconds. After CPB, heparin was reversed by $3 \mathrm{mg} / \mathrm{kg}$ protamine chloride (Hoffman/Laroche BV, Mijndrecht, The Netherlands). Reversal of the heparin effect was determined by heparin/protamine titration (Heparin assay cartridges, 
Medtronic HemoTec, Inc., Englewood, Colorado, USA) on the Hepcon System-Four (Medtronic HemoTec, Inc., Englewood, Colorado, USA). All pump blood was returned to the patient through the aortic cannula or intravenously via infusion bags without hemoconcentration.

\section{Blood sampling}

Blood samples were taken for routine blood gas analyses and for hematological, biochemical and coagulation studies before heparin administration (sample point 1), 5 minutes after beginning of $\mathrm{CPB}$ (sample point 2), 60 minutes after the beginning of CPB (i.e. after aorta occlusion, sample point 3), 15 minutes after protamine administration (sample point 4), 2 hours after closure of the sternum (sample point 5), and 24 hours after surgery (sample point 6 ).

\section{Measurements}

Plasma anticoagulated with a special cocktail (a buffer of EDTA, benzamidine and soy bean trypsin inhibitor, $\mathrm{pH}$ 7.4) was obtained by centrifugation of whole blood at $4000 \mathrm{~g}$ for 5 minutes and stored at $-70^{\circ} \mathrm{C}$ for further determination of kallikrein- $\mathrm{C}_{1}$-inhibitor complexes, by a radio immuno assay (RIA) with ${ }^{125} \mathrm{I}$-anti- $\mathrm{C}_{1}$-inhibitor as a marker. Plasma (platelet-poor) for determination of thrombin-antithrombin complexes, prothrombin fragment $1+2$ and plasmin- $\alpha_{2}$-antiplasmin was obtained by centrifugation of whole blood, anticoagulated with sodium citrate $3.5 \%$, at $4000 \mathrm{~g}$ for 5 minutes, and the supernatant was centrifuged at $12000 \mathrm{~g}$ for 10 minutes and stored at $-70^{\circ} \mathrm{C}$ for further determination, by enzyme-linked immunosorbent assay (ELISA, Behringwerke AG, Marburg, Germany). Platelet-rich plasma for determination of platelet procoagulant activity was obtained by centrifugation of whole blood, anticoagulated with acid-citrate-dextrose buffer (ACD), at $1000 \mathrm{~g}$ for 12 minutes and prepared for flowcytometric analysis on a FacScan (Becton Dickinson, San José, CA, USA). Ionomycine was used as an activator and Annexin V-FITC (fluorescein isothiocyanate) for fluorescent labeling of the procoagulant phospholipids sites.

At the end of perfusion, eight arterial line filters (i.e. four AF 1040 Gold and four Sartorius) were randomly chosen and carefully rinsed, fixed and analyzed using a scanning electron microscope. The clinical outcome of all patients regarding morbidity and mortality was monitored. Also the blood loss from the chest tubes within the initial 24 hours after the patient arrived at the intensive care unit was recorded. 


\section{Statistical analysis}

The results were expressed as the mean \pm standard error of the mean (SEM). The rank sum two-sample test (Mann-Whitney) was used for statistical analysis of differences between both experimental groups. A $p$ value of less than 0.05 was considered to indicate statistically significant difference between measured values.

\section{RESULTS}

\section{Kallikrein-C1-inhibitor}

The kallikrein- $\mathrm{C}_{1}$-inhibitor complexes in both the Duraflo II group and the control group hardly exceed the baseline value (i.e. the mean value of both groups before interaction of blood with material, sample point 1 ). Thus, indicating that activation of the coagulation process was not initiated by the intrinsic pathway (Figure 1).

\section{Prothrombin fragment $1+2$}

Plasma prothrombin fragment $1+2\left(\mathrm{~F}_{1+2}\right)$ complex formation increased with time on $\mathrm{CPB}$, but did not differ between the Duraflo II and the control group. The extent of $\mathrm{F}_{1+2}$ complex formation in both groups reached a maximum value fol-

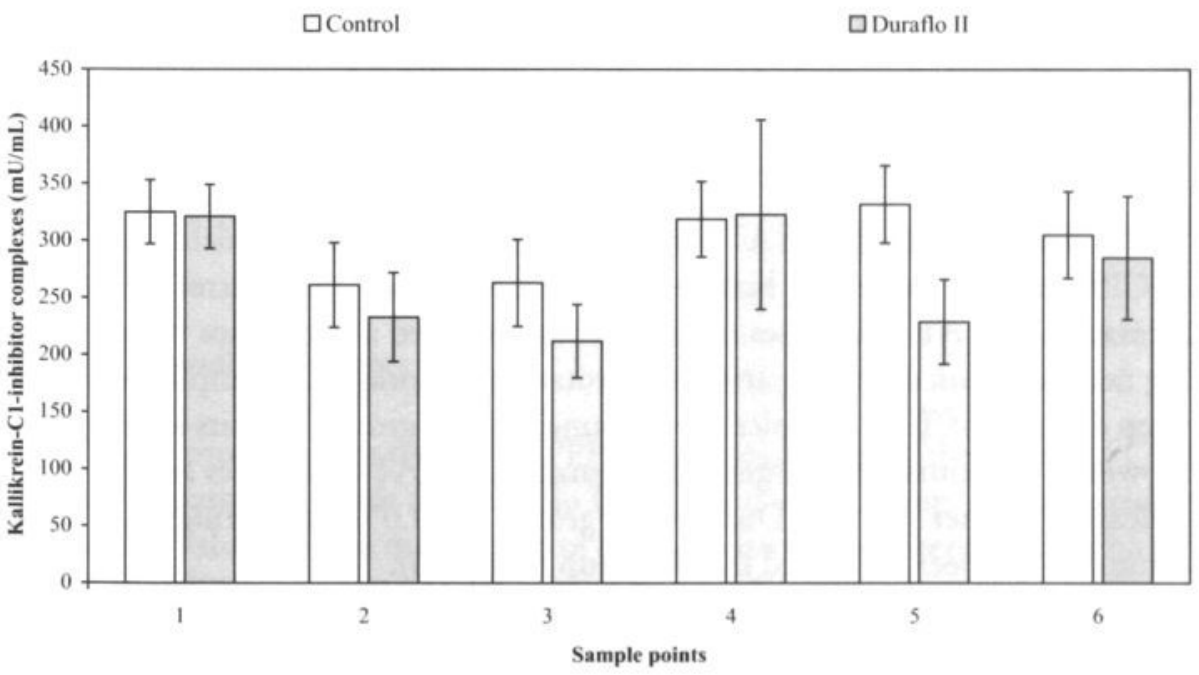

Figure 1 Kallikrein- $C_{1}$-inhibitor complexes. The numbers on the ordinate refer to sampling times as described in the "Materials and Methods" section. Data are presented as mean \pm SEM. 


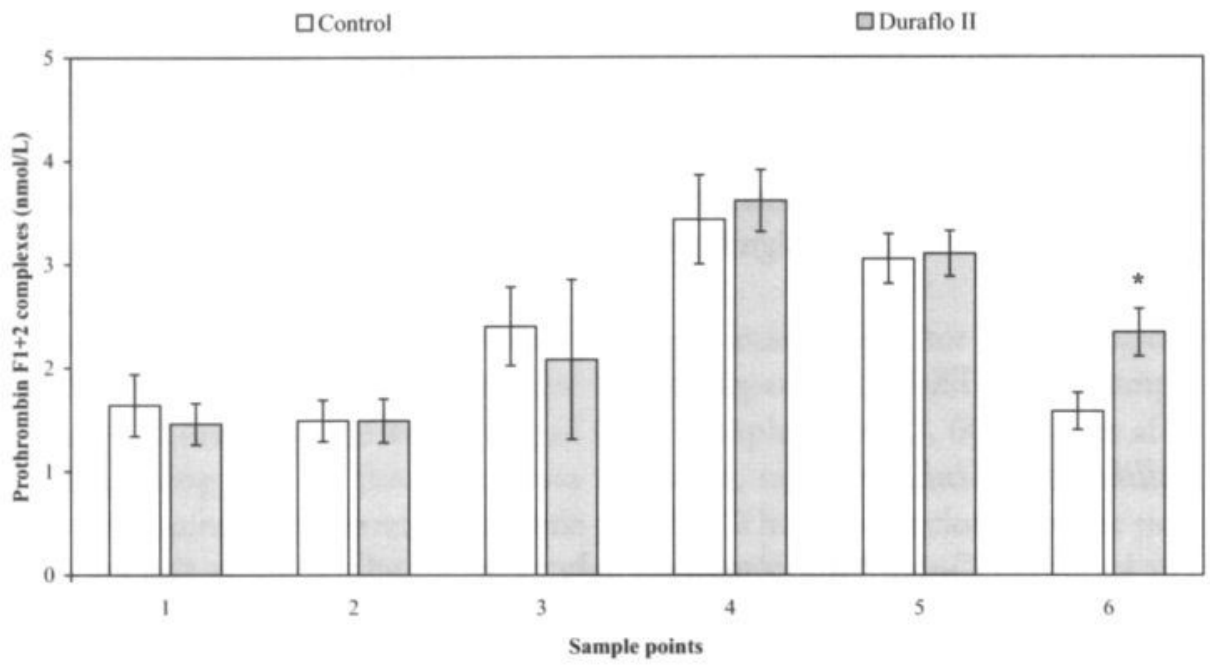

Figure 2 Plasma prothrombin fragment F 1+2 complexes. The numbers on the ordinate refer to sampling times as described in the "Materials and Methods" section. Data are presented as mean \pm SEM. An asterisk indicates a statistically significant difference between the two groups $(P<0.05$ by rank sum two sample test).

lowing the neutralization of the heparin with protamine chloride (i.e. sample point 4). In a later phase of the postoperative period (i.e. 24 hours after surgery, sample point 6$)$, the formation of $\mathrm{F}_{1+2}$ complex was significantly higher $(P<0.05)$ in the Duraflo II group indicating that more thrombin has been generated in this group (Figure 2).

\section{Thrombin-antithrombin}

Thrombin-antithrombin (TAT) complex formation increased during the course of CPB, but did not differ between the Duraflo II and the control group. The formation of TAT complexes in both groups reached a maximum value following neutralization of the heparin with protamine chloride (i.e. sample point 4). A steep decrease of TAT complexes was found in both groups 2 hours after surgery. However, 24 hours after surgery the formation of TAT complexes remained significantly higher in the Duraflo II group $(P<0.05)$ indicating that more thrombin has been inhibited in this group (Figure 3). 


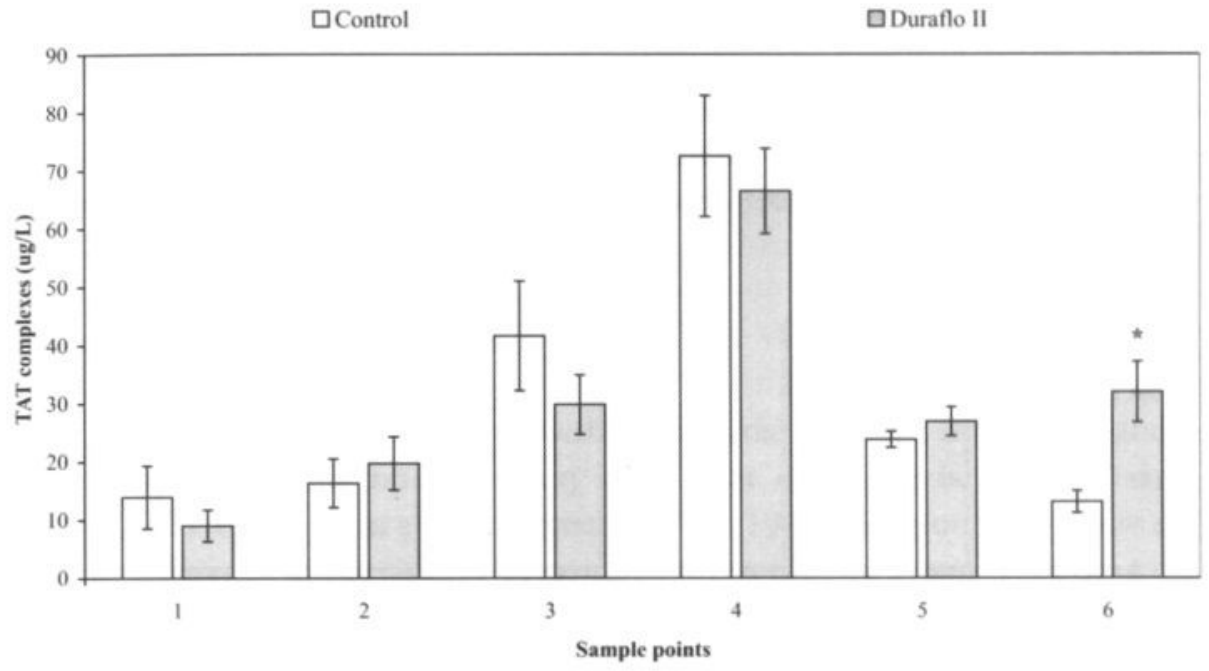

Figure 3 Thrombin-antithrombin complexes. The numbers on the ordinate refer to sampling times as described in the "Materials and Methods" section. Data are presented as mean \pm SEM. An asterisk indicates a statistically significant difference between the two groups $(P<0.05$ by rank sum two sample test).

\section{Plasmin- $\alpha_{2}$-antiplasmin}

Plasmin- $\alpha_{2}$-antiplasmin (PAP) complex formation decreased after the start of $\mathrm{CPB}$ (sample point 2) in a similar pattern in both the Duraflo II and the control group. After neutralization of heparin with protamine chloride (sample point 4), $\mathrm{PAP}$ increased remarkably in both groups, and persisted elevated for up to $2 \mathrm{~h}$ after CPB. Twenty-four hours after surgery the PAP-values had returned to normal values in both groups indicating normalization of the fibrinolytic system (Figure 4).

\section{Platelet procoagulant assay}

The platelet procoagulant potential (PPP) was elevated during the course of $\mathrm{CPB}$ in a similar pattern in both the Duraflo II and the control group, as compared to the baseline value (i.e. the mean value of both groups before interactions of blood with material, sample point 1). Also after surgery the PPP values in both groups remained elevated. However, in a later phase (i.e. 24 hours after surgery) the PPP was significantly higher in the Duraflo II group $(P<0.05)$, indicating a higher excitability of the procoagulant phospholipids activity of platelets (Figure 5). 


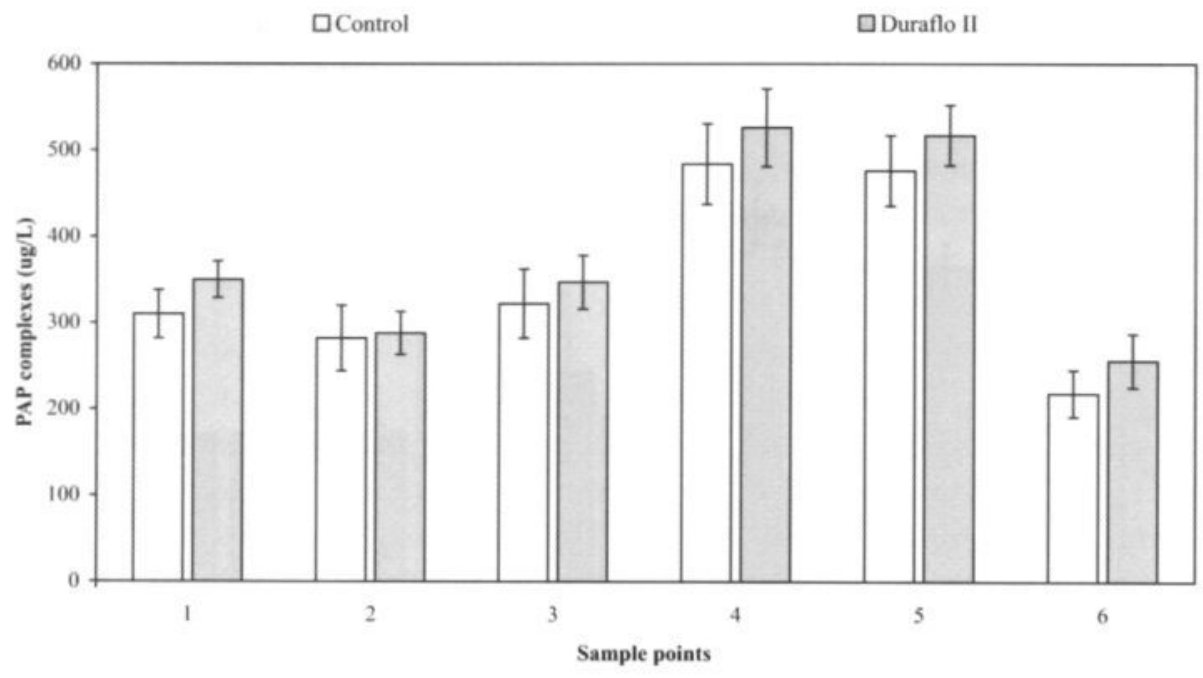

Figure 4 Plasmin- $\alpha_{2}$-antiplasmin complexes. The numbers on the ordinate refer to sampling times as described in the "Materials and Methods" section. Data are presented as mean \pm SEM.

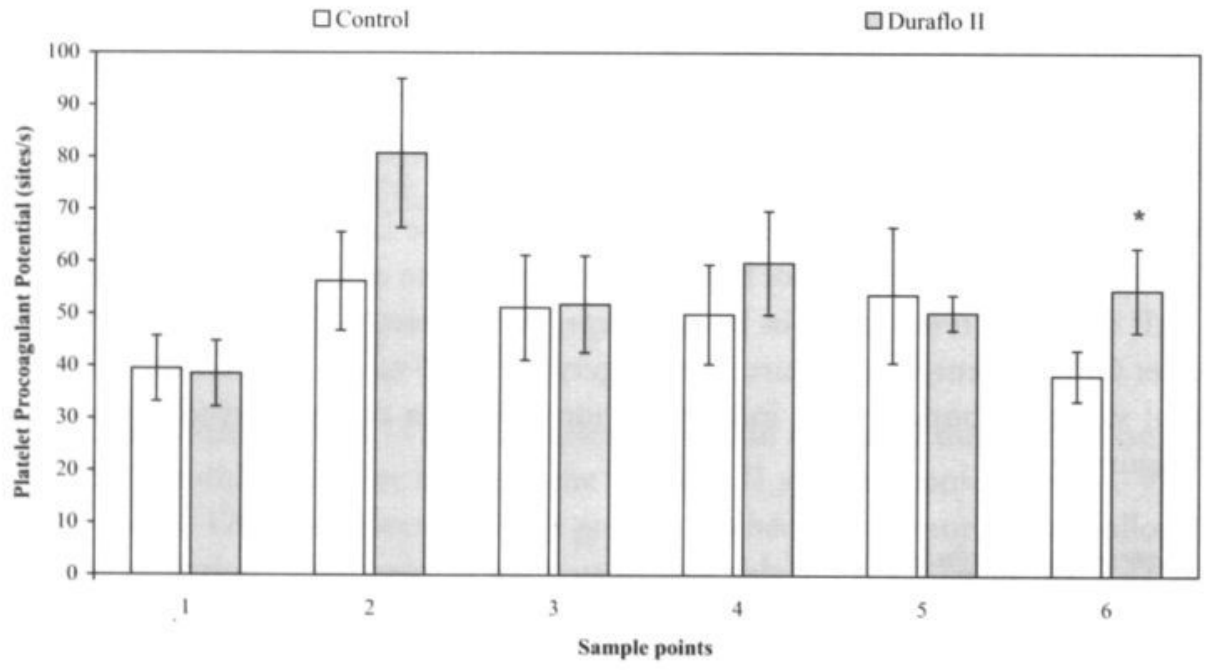

Figure 5 Platelet procoagulant assay. The numbers on the ordinate refer to sampling times as described in the "Materials and Methods" section. Data are presented as mean \pm SEM. An asterisk indicates a statistically significant difference between the two groups $(P<0.05$ by rank sum two sample test). 


\section{Scanning electron microscopy}

Scanning electron micrographs of the examined arterial line filters showed less adhesion and pseudopod formation of platelets on the control arterial line filter (Sartorius) compared to the Duraflo II heparin-treated arterial line filter (AF 1040 Gold), figure 6 and 7.

\section{Blood loss and clinical outcome}

The blood loss from the chest tubes within the initial 24 hours after arrival at the intensive care unit did not show any significant difference between the two groups ( $1401 \pm 189 \mathrm{ml}$ in group A versus $1275 \pm 196 \mathrm{ml}$ in group B). There existed no difference in the clinical outcome between the two groups regarding the duration of intensive care unit stay (1 day in both groups) and the duration of hospital stay ( $11 \pm 2$ days in group A versus $10 \pm 2$ days in group B).

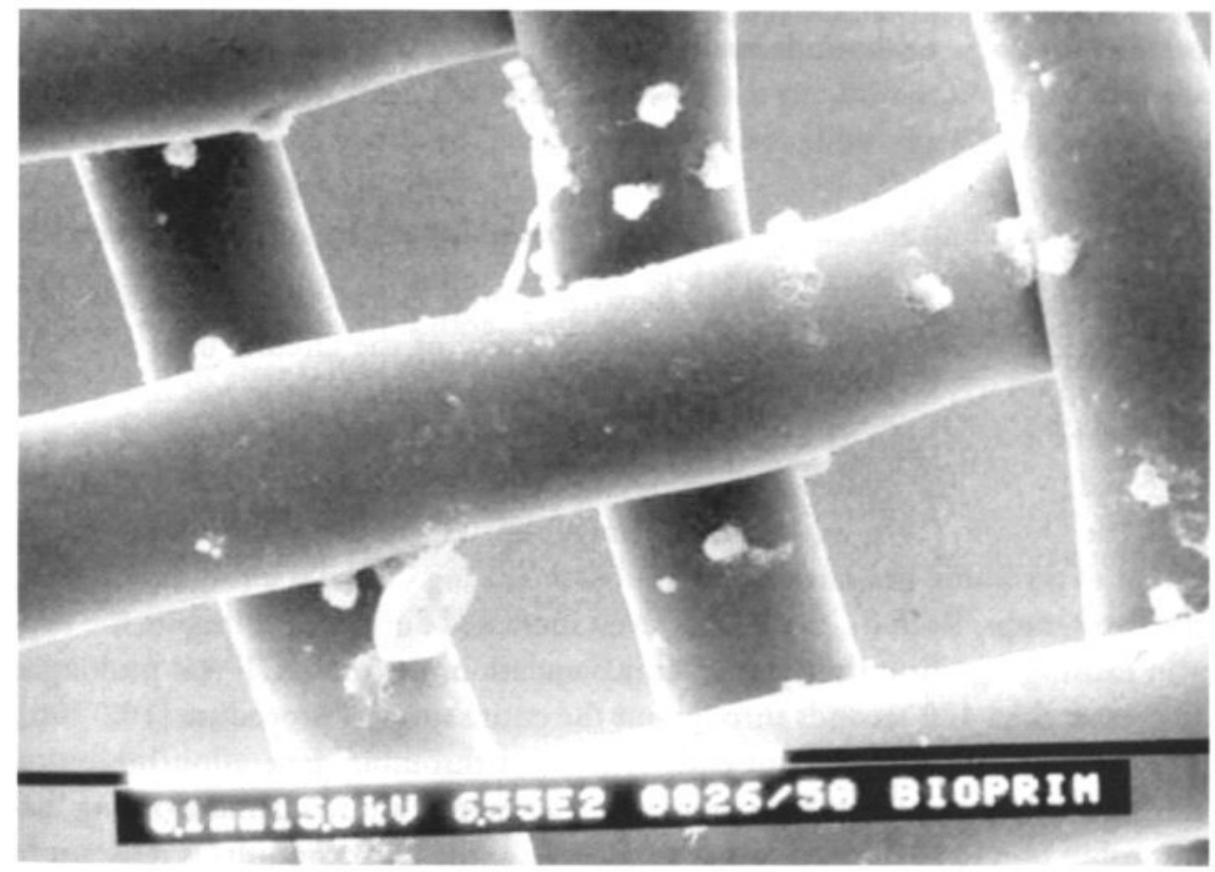

Figure 6 Scanning electron micrograph of the Sartorius arterial line filter screen (control filter) after cardiopulmonary bypass. 


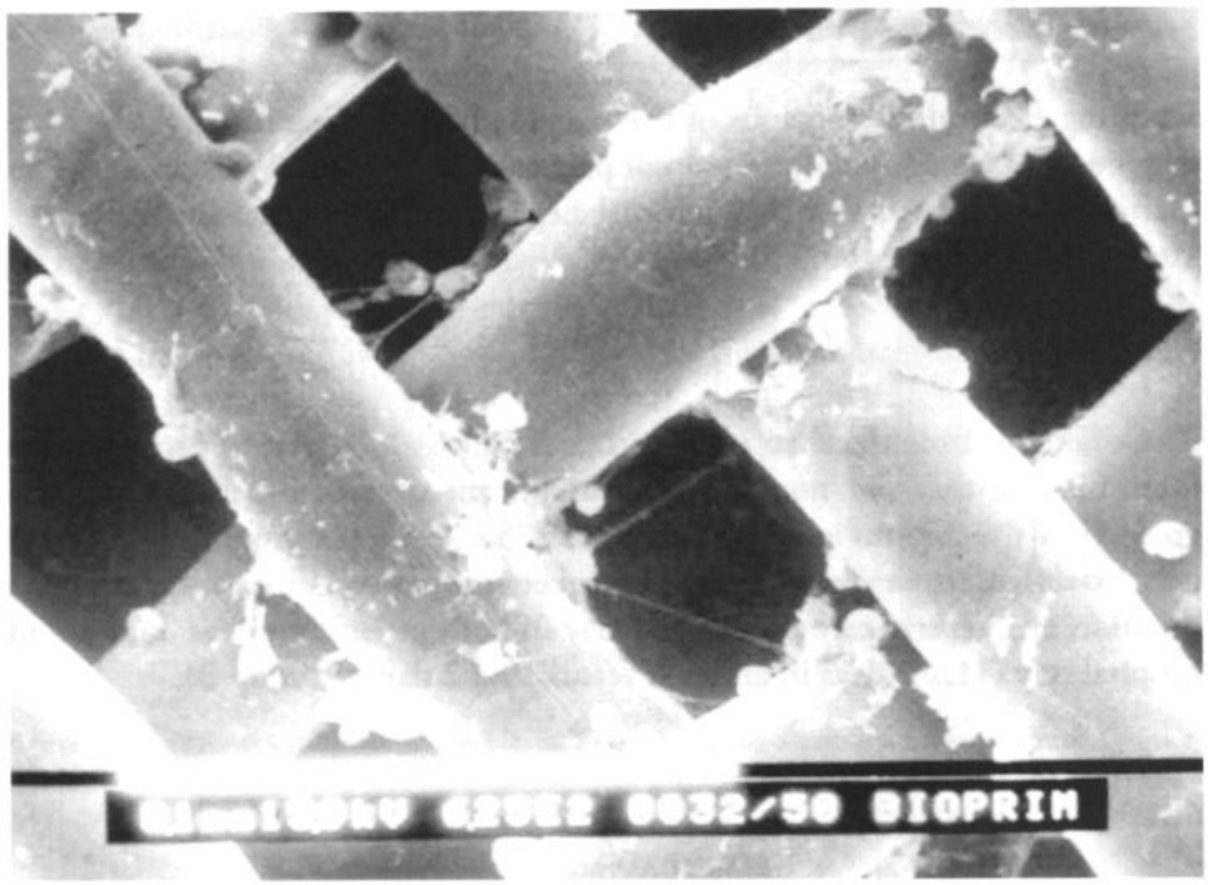

Figure 7 Scanning electron micrograph of the Duraflo II heparin-treated arterial line filter screen (AF 1040 Gold) after cardiopulmonary bypass.

\section{DISCUSSION}

According to many investigators heparin-treated extracorporeal circuits is a promising approach to improve biocompatibility of the circuits used for $\mathrm{CPB}$ $[29,35,93,95,97,98,100]$. The present clinical study clearly indicates that activation of the coagulation process is not initiated by the intrinsic pathway. This was reflected by the low amounts of kallikrein- $\mathrm{C}_{1}$-inhibitor complexes $(<1 \mathrm{U} / \mathrm{ml})$ in both the Duraflo II group and the control group. The results also showed that the extent of thrombin generation and inhibition during CPB did not differ between the two groups. Both $\mathrm{F}_{1+2}$ and TAT levels increased during $\mathrm{CPB}$ despite the heparin causing significantly systemic anticoagulation, i.e. the ACT was prolonged to greater than 480 seconds throughout the entire surgical procedure [102-106]. That systemic heparin did not entirely prevent thrombin generation/inhibition during $\mathrm{CPB}$, is consistent with previous experimental studies demonstrating that thrombin bound to fibrin or other surfaces (e.g. the CPB conduit) is resistant to anti-thrombin III-heparin inhibition, and thus able to facilitate further thrombin generation [107-111]. The observation that both the $\mathrm{F}_{1+2}$ and TAT levels are sig- 
nificantly elevated in the Duraflo II group 24 hours after cardiac surgery, suggests that more thrombin is generated in the Duraflo II group. However, fibrinolysis in both groups returns to a normal value, 24 hours after surgery [112-114], expressed by the normal levels of PAP complex. Persisting fibrinolysis for up to 2 hours after $\mathrm{CPB}$ is in accordance with the elevated $\mathrm{F}_{1+2}$ levels (i.e. the thrombin generation) [115-121]. However, to what extent the impairment of hemostasis was not prevented is not entirely clear. Since it has also been suggested that due to cardiotomy suction containing plasminogen activator-like substances from pleural, pericardial, and periosteal surfaces could also be an initiator of fibrinolytic activity $[114,122]$. Furthermore, the excitability of the procoagulant phospholipids activity of platelets in the Duraflo II group was significantly higher, 24 hours after surgery.

There was no significant difference in procoagulant activity during CPB between both groups. The clinical importance of the procoagulant activity of platelets on the hemostasis during and after CPB is not entirely clear, and has to be further investigated. What also needs to be further investigated is the influence of heparin bonding to the extend of adhesion and pseudopod formation of platelets on the arterial filter screens.

Despite the significant differences in thrombin generation/inhibition and procoagulant phospholipids activity of platelets between both groups 24 hours after surgery, the clinical outcome of the patients showed no significant differences. The blood loss from the chest tubes within the initial 24 hours after the patient arrived at the intensive care unit also did not show any significant difference between the two groups.

In summary, during cardiopulmonary bypass no significant difference could be detected between the Duraflo II group and the control group in regard to thrombin generation/inhibition and procoagulant phospholipids activity of platelets. But, after CPB (i.e. 24 hours after surgery) the patients in the Duraflo II group showed a significantly elevated thrombin generation/inhibition and also the excitability of the procoagulant phospholipids activity of platelets was significantly higher. Based on these results the advantage of using Duraflo II heparin treated extracorporeal circuits during routine clinical $\mathrm{CPB}$ procedures could not be confirmed. 



\section{CHAPTER 3}

\section{Influence of Duraflo II heparin-treated extracorporeal circuits on the systemic inflammatory response in patients having coronary bypass}

P.W. Weerwind ${ }^{1}$, J.G. Maessen ${ }^{2}$, L.J.H. van Tits ${ }^{3}$, R.K. Stad ${ }^{3}$, E.J. Fransen ${ }^{2}$, D.S. de Jong ${ }^{1}$, O.C.K.M. Penn ${ }^{2}$.

Departments of ${ }^{1}$ Extracorporeal Circulation, ${ }^{2}$ Cardiothoracic Surgery,

${ }^{3}$ General Surgery, University Hospital Maastricht, The Netherlands.

J Thorac Cardiovasc Surg 1995;110:1633-1641.

Abstract was winner of the Best Paper Award, during the Sixth European Congress on Extra-Corporeal Circulation Technology, Waterloo, Belgium, June 7-10, 1995. 


\section{ABSTRACT}

Objective. This study was conducted to evaluate whether the use of heparin-treated extracorporeal circuits could reduce the inflammatory reaction during cardiopulmonary bypass (CPB).

Methods. A prospective clinical study was carried out on fourteen coronary artery bypass grafting (CABG) patients perfused randomly with either Duraflo II heparin-treated circuits or with non-treated circuits. In both groups systemic heparinization was performed before $\mathrm{CPB}$.

Results. The use of heparin-treated circuits resulted in a reduction of systemic inflammatory activation during $\mathrm{CPB}$. This was reflected by lower plasma levels of soluble tumor necrosis factor receptors $(P<0.05)$, interleukin-6, and interleukin-8 $(P<0.05)$, manifest after release of the aortic crossclamp. Furthermore, 6 and 12 hours after aortic crossclamp release significant lower levels of the soluble E-selectin $(P<0.05)$ were observed in the Duraflo II group. In patients whom non-coated circuits were used, a significant decrease in circulating soluble intercellular adhesion molecule-1 $(P<0.05)$ was found early during bypass.

Conclusion. All these observations suggest that the use of a heparin-treated extracorporeal circuit reduces the systemic inflammatory activation, and may alter the leukocyte-endothelium interaction. 


\section{INTRODUCTION}

During cardiopulmonary bypass (CPB), leukocyte contact with synthetic surfaces initiates a host defense reaction with the characteristics of a systemic inflammatory response syndrome. Leukocyte activation during CPB includes release of proteolytic enzymes, changes in leukocyte adhesiveness and leukocyte sequestration in tissue beds, especially in the lungs with the potential danger of microvascular plugging and capillary leakage. Besides contact activation, ischemia reperfusion injury, the reinfusion of shed blood and hemodilution may contribute to the increased leukocyte adherence to vascular endothelium. The adhesion of leukocytes to endothelium creates a microenvironment in which damaging products of activated leukocytes are released in close contact with vascular endothelium resulting in further endothelial activation or even endothelial injury [123-126].

Although the large size of leukocytes and their relative lack of deformability make these cells easy to be trapped physically within the endothelial lining [127-129], the interaction between leukocytes and endothelium is largely mediated by biochemical processes [130-132]. The adhesive interactions between leukocytes and endothelial cells are mediated in large part by specific leukocyte and endothelial adhesion molecules [133-137]. It has been shown that the adhesion molecules ICAM-1 (intercellular adhesion molecule-1), and E-selectin are inducible on the endothelial surface [138-141]. The proinflammatory cytokines tumor necrosis factor (TNF), interleukin-6 (IL-6), interleukin-8 (IL-8) are known to stimulate endothelial cells to increase the expression of these molecules and thus facilitate leukocyte adherence [142-144]. Moreover, Il-8 is a major neutrophil chemotactic and activating factor produced by various types of human cells.

Modification of the material surface of the heart-lung machine has been recognized as a technique to change the interaction with blood. Originally, this method was designed to allow application of thromboresistant characteristics to the materials $[92,94,145,146]$. Later, it was found that heparin coating of the material surface reduced complement activation and might thus bear the potential to change leukocyte activation $[46,47]$ and subsequently the leukocyte-endothelium interaction. Therefore, the purpose of this study was to evaluate whether the use of heparin-treated (Duraflo II surface, Bentley/Baxter Inc., Irvine, CA, USA) extracorporeal circuits could reduce the leukocyte-mediated inflammatory response in patients undergoing $\mathrm{CPB}$. 


\section{PATIENTS AND METHODS}

\section{Patients}

Fourteen adult patients subsequently undergoing elective coronary artery bypass grafting were enrolled in this study. The patients were randomly divided into two groups with $(A, n=7)$ or without $(B, n=7)$ the use of a heparin-treated extracorporeal circuit. Exclusion criteria were the following: previous cardiac surgery, congestive cardiac failure, neurological disorders (e.g. cerebrovascular accident), severe pulmonary disorders (e.g. chronic obstructive pulmonary disease, emphysema), insulin/non-insulin dependent diabetics, renal diseases (e.g. renal failure), liver diseases and pre-operative coagulopathies. Informed consent was obtained from each patient the day before the operation. The study was approved by the local ethical and research council.

\section{Anesthesia and monitoring}

Standard anesthetic (lorazepam, fentanyl citrate, sufentanil citrate, alfentanil hydrochloride, midazolam hydrochloride, pancuronium bromide) and monitoring techniques (electrocardiogram, central venous/pulmonary and arterial pressure monitoring, urinary output, rectal and skin temperature monitoring) were used in both groups. Cefuroxim was used for antibiotic treatment, and the first dose was administered before sternotomy.

Before connection of the extracorporeal circuit for CPB, heparin $(300 \mathrm{IU} / \mathrm{kg}$, Heparin Leo, Leo Pharmaceutical Products BV, Weesp, The Netherlands) was administered in order to achieve an activated coagulation time (ACT) greater than 480 seconds (Hemochron 400, International Technidyne Corp., New Jersey, USA).

\section{Cardiopulmonary bypass}

The main components in the extracorporeal circuit consisted of a hollow fiber membrane oxygenator (Univox; Bentley/Baxter), a venous reservoir (BMR1900; Bentley/Baxter), a cardiotomy reservoir (in group A: BCR-3500 Gold; Bentley/Baxter, in group B: William Harvey H4700; C.R.Bard Inc., Tewsbury, MA, USA.), and an arterial line filter (in group A: AF 1040 Gold; Bentley/Baxter, in group B: Sartorius; Sartorius AG, Göttingen, Germany.). In group A, all components exposed to blood were pretreated with heparin-bonded coating (Duraflo II). The standard priming of the extracorporeal circuit was $1300 \mathrm{ml}$ Haemaccel 3.5\% (Behringwerke AG, Marburg, Germany), $200 \mathrm{ml}$ 
Mannitol 20\%, $100 \mathrm{ml} \mathrm{H}$-Albumin 20\%, $50 \mathrm{ml} \mathrm{NaHCO} 38.4 \%, 20 \mathrm{ml} \mathrm{KCl}$ $7.45 \%$ (B.Braun Medica BV, Uden, The Netherlands) and 6500 IE Heparin Leo. After institution of cardiopulmonary bypass at a flow rate of $2.4 \mathrm{~L} / \mathrm{min} / \mathrm{m}^{2}$, and after reaching a blood temperature below $28^{\circ} \mathrm{C}\left(25-28^{\circ} \mathrm{C}\right)$, the heart was topically cooled till fibrillation using cold saline $0.9 \%$ at $4{ }^{\circ} \mathrm{C}$. The aorta was then crossclamped and a single dose of approximately $800 \mathrm{ml}(600-1000 \mathrm{ml})$ of St.Thomas' Hospital No. 1 cardioplegic solution at $4^{\circ} \mathrm{C}$ was infused into the aortic root in a period of 4 minutes (3-5 minutes) to provide myocardial preservation. Topic cooling was maintained during the infusion of the cardioplegic solution.

Target flow rates of $2.4 \mathrm{~L} / \mathrm{min} / \mathrm{m}^{2}$ were maintained at normothermia and correspondingly lower rates of $2.0 \mathrm{~L} / \mathrm{min} / \mathrm{m}^{2}\left(1.8-2.2 \mathrm{~L} / \mathrm{min} / \mathrm{m}^{2}\right)$ were maintained at moderate hypothermia of $28^{\circ} \mathrm{C}$, depending on the venous oxygen saturation and the arterial pressure. Pulsatile perfusion was used throughout the period of aorta crossclamping. During the conduct of $\mathrm{CPB}$ attention was given to restrict, and if possible, to avoid the use of the cardiotomy suction. The cardiotomy suction and aortic root venting were in all cases less than $2 \%$ of the calculated flow $(<90$ $\mathrm{ml} / \mathrm{min}$, intermittent). A volume pressure control unit was used, with negative pressures less than $60 \mathrm{mmHg}$. In all patients the left anterior descending coronary artery was revascularized with the left internal mammary artery. Papaverine was locally applied to the mammary artery after dissection to prevent spasm. After completion of all the distal anastomoses, the aortic crossclamp was removed and the proximal anastomosis was performed with a partial occlusion clamp after spontaneous or electrical defibrillation, while the rewarming of the patient to $37^{\circ} \mathrm{C}$ continued. Additional heparin was administered during bypass if the ACT was lower than 400 seconds. After CPB, heparin was reversed by $3 \mathrm{mg} / \mathrm{kg}$ protamine chloride (Hoffman/Laroche BV, Mijndrecht, The Netherlands). Reversal of the heparin effect was determined by heparin/protamine titration (Heparin assay cartridges, Medtronic HemoTec, Inc., Englewood, Colorado, USA) on the Hepcon System-Four (Medtronic HemoTec, Inc., Englewood, Colorado, USA). All pump blood was returned to the patient through the aortic cannula or intravenously via infusion bags without hemoconcentration.

\section{Plasma samples}

Blood samples were taken after induction of anesthesia, before aortic crossclamping, after release of the aortic crossclamp (i.e. start reperfusion), and $1 / 2,1 \frac{1}{2}, 3,6,12,24$ hours after release of the aortic crossclamp. Blood was collected in evacuated blood collection tubes containing ethylenediaminetetraacetic acid. Plasma was separated from blood cells by centrifugation at $1000 \mathrm{~g}$ for 5 minutes and stored at $-70^{\circ} \mathrm{C}$ until analysis. 


\section{Measurement of inflammatory mediators}

Inflammatory mediators were measured using sandwich enzyme-linked immunosorbent assay (ELISA) that have been described elsewhere [147-150]. In short, immunoassay plates (Nunc-Immuno Plate Maxisorp, Roskilde, Denmark) were coated with MAbs MR1-1, MR2-2, HM2 and ENA1 for measurement of sTNF-R55, sTNF-R75, sICAM-1 and sE-selectin respectively. After washing, the plates were incubated with plasma samples followed by incubation with specific biotin-labeled polyclonal rabbit anti-sTNF-R IgG, biotin-labeled MAb HM1 and MAb ENA2 for sICAM-1 and sE-selectin detection respectively. After washing, peroxidase labeled streptavidin (Dako, Glostrup, Denmark) was added, while TMB (3,3,'5,5'-tetramethylbenzidine, Kirkegaard \& Perry Lab., Gaithersburg, MD) was used as a substrate. Photospectometry $(450 \mathrm{~nm})$ was performed using a micro ELISA autoreader. Standard curves were constructed using dilutions of human sTNF-R55, sTNF-R75, sICAM-1 and sE-selectin with known concentrations. The lower detection limits of the assays were $100 \mathrm{pg} / \mathrm{ml}$ for TNF receptors, $400 \mathrm{pg} / \mathrm{ml}$ for sICAM and $1 \mathrm{ng} / \mathrm{ml}$ for sE-selectin. Similarly, ELISA assays were used to determine plasma IL-6, Il- 8 and TNF- $\alpha$ levels. For this purpose, plates were coated with MAbs 5E1, HM5 and 61E71 respectively. Upon incubation with plasma samples, the Il- 6 and TNF- $\alpha$ assays were incubated with polyclonal rabbit anti-human IL-6 IgG or polyclonal rabbit anti-human TNF- $\alpha$ IgG followed by peroxidase conjugated goat anti-rabbit IgG (Jackson ImmunoResearch, Westgrove, PA). For the detection of IL-8 biotin-labeled polyclonal rabbit anti-human IL-8 followed by streptavidin-peroxydase conjugate was used. In these assays TMB was used as a substrate. Human rIL-6, human rIL- 8 and human TNF- $\alpha$ were used for standard titration curves. The lower detection level was $10 \mathrm{pg} / \mathrm{ml}$ for IL-6, $100 \mathrm{pg} / \mathrm{ml}$ for IL-8 and $20 \mathrm{pg} / \mathrm{ml}$ for TNF- $\alpha$.

\section{Statisical analysis}

The results were expressed as the mean \pm standard error. The Wilcoxon rank sum test was used for statistical analysis of differences between both experimental groups. The Wilcoxon matched-pairs signed-ranks test was used for analysis of differences between control values and different time points within one group. A $p$ value of less than 0.05 was considered to indicate a statistically significant difference between measured values 


\section{RESULTS}

\section{Patients}

No significant difference existed between the two groups as related to sex, age, bodyweight, height, as well as bypass time and aortic crossclamp time (Table 1).

\section{sIL-6 and $s I L-8$}

Changes in IL-6 plasma concentrations with time in group A and B are shown in figure 1. In the patients who underwent $\mathrm{CPB}$ without heparin-coated extracorporeal circuits (group B) a rise in IL-6 concentration from the preoperative level of less than $10 \mathrm{pg} / \mathrm{ml}$ was detected from the time of the start of the reperfusion. After the peak value of $1.60 \pm 1.31 \mathrm{pg} / \mathrm{ml}$, which occurred 1.5 hour after the start of the reperfusion, concentrations declined to preoperative values 24 hours after the release of the aortic crossclamp. In contrast, a modest increase in plasma IL-6 levels was observed in patients treated with the heparin-coated extracorporeal circuits (group A). IL-6 levels rose to $0.36 \pm 0.06 \mathrm{pg} / \mathrm{ml} 12$ hours after reperfusion and then gradually declined to preoperative levels.

As soon as CPB was started, circulating IL-8 levels rose in patients of group B. A profound increase, however, was not found until the start of reperfusion. A peak level of $0.65 \pm 0.55 \mathrm{ng} / \mathrm{ml}$ was reached at 1.5 hours of reperfusion. Then plasma levels rapidly declined. Notably, in three out of seven patients IL-8 levels were still elevated at 24 hours. In patients treated with the heparin-coated circuit (group A), a completely different pattern was observed. During surgery and early during reperfusion no change in IL-8 levels occurred. At 6 hours post-reperfusion, a modest increase of $0.21 \pm 0.18 \mathrm{ng} / \mathrm{ml} \mathrm{IL-} 8$ was found. At 24 hours after the start of reperfusion no significant differences were observed between the control and the Duraflo II group (Figure 2).

Table 1 Clinical characteristics of the patients groups. No significant difference existed between the two groups. The values are expressed in mean \pm standard deviation.

$$
\text { Duraflo II (group A) Control (group B) }
$$

No.

$$
7
$$

$\operatorname{Sex}(\mathrm{M} / \mathrm{F})$

$6 / 1$

Age (years)

$58 \pm 12$

$6 / 2$

Height $(\mathrm{cm})$

$176 \pm 9$

$61 \pm 11$

Weight $(\mathrm{kg})$

$86 \pm 14$

$173 \pm 14$

Bypass time ( $\mathrm{min}$ )

$82 \pm 24$

$78 \pm 8$

Aortic crossclamp time (min)

$51 \pm 18$

$82 \pm 20$

$53 \pm 20$ 


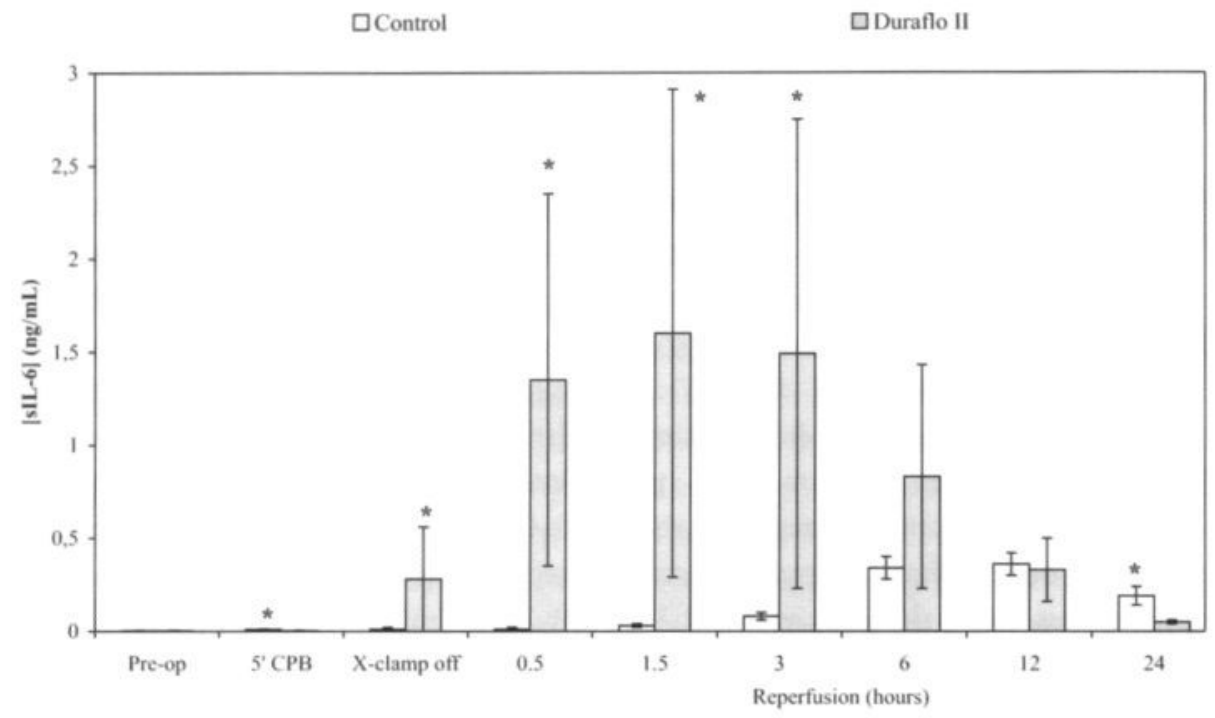

Figure 1 Circulating plasma levels of IL-6, mean ( \pm standard error) in patients who underwent CPB with coated (cross-hatched bars) and non-coated (bars) circuits. Statistically significant differences $(P<0.05)$ between the groups are indicated with an asterisk. Pre-op indicates sample taken after induction of anesthesia; CPB, sample taken before aortic crossclamping; and X-clamp off, sample taken after release of the aortic crossclamp (i.e. start reperfusion).

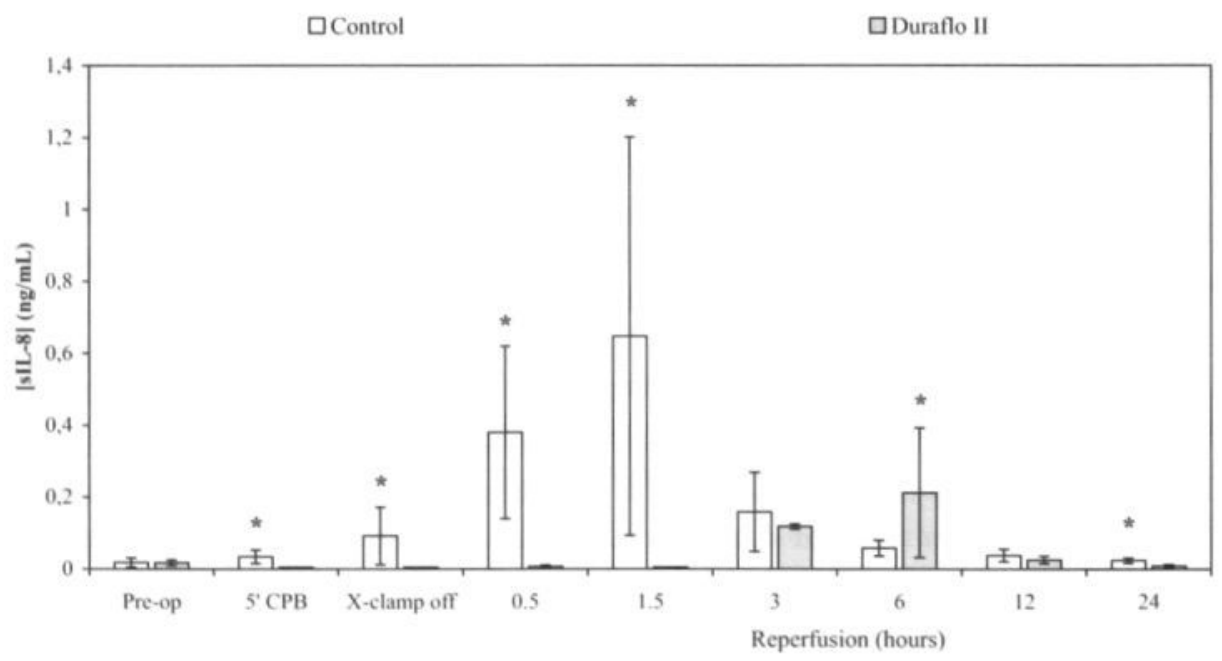

Figure 2 Circulating plasma levels of IL-8, mean ( \pm standard error) in patients who underwent CPB with coated (cross-hatched bars) and non-coated (bars) circuits. Statistically significant differences $(P<0.05)$ between the groups are indicated with an asterisk. Abbreviations as in Figure 1. 


\section{TNF, sTNF-R55 and sTNF-R75}

In the present study no increase in TNF- $\alpha$ levels could be demonstrated (not shown). Only in one patient, the detection level of our assay was reached. The peak level was $74 \mathrm{pg} / \mathrm{ml}$ and this level was found at $1 / 2$ hour after reperfusion (data not shown). Interestingly, in this patient peak levels of sELAM, sTNF-R55, sTNF-R75, and IL-8, but not sICAM, were higher than the peak levels of these cytokines in any other patient.

Preoperative levels of sTNF-R were not significantly different between both groups. CPB caused increases in plasma levels of both sTNF-R. However, kinetics of sTNF-R levels were different between both groups. In the control group (extracorporeal circuit without heparin coating), sTNF-R levels started to increase as early as during CPB. sTNF-R remained elevated from $1 / 2$ to 6 hours after release of the aortic clamp, and then slowly declined again. This pattern was similar for both TNF-R. Enhancement of sTNF-R levels in plasma of patients with heparin-coated circuit was significantly delayed: no increase was found until three hours after release of the aortic clamp. From 6 to 24 hours onwards, TNF receptor levels were in the same range in both groups (Figures 3 and 4).

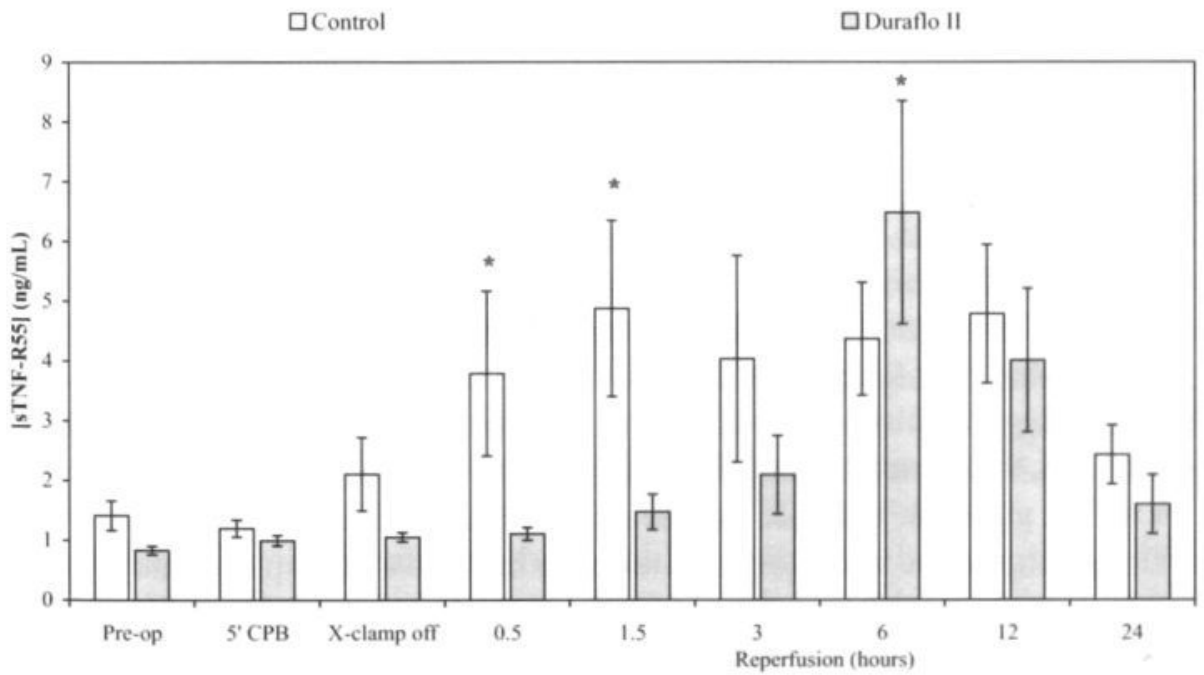

Figure 3 Circulating plasma levels of soluble TNF-R55, mean ( \pm standard error) in patients who underwent $\mathrm{CPB}$ with coated (cross-hatched bars) and non-coated (bars) circuits. Statistically significant differences $(P<0.05)$ between the groups are indicated with an asterisk. Abbreviations as in Figure 1. 


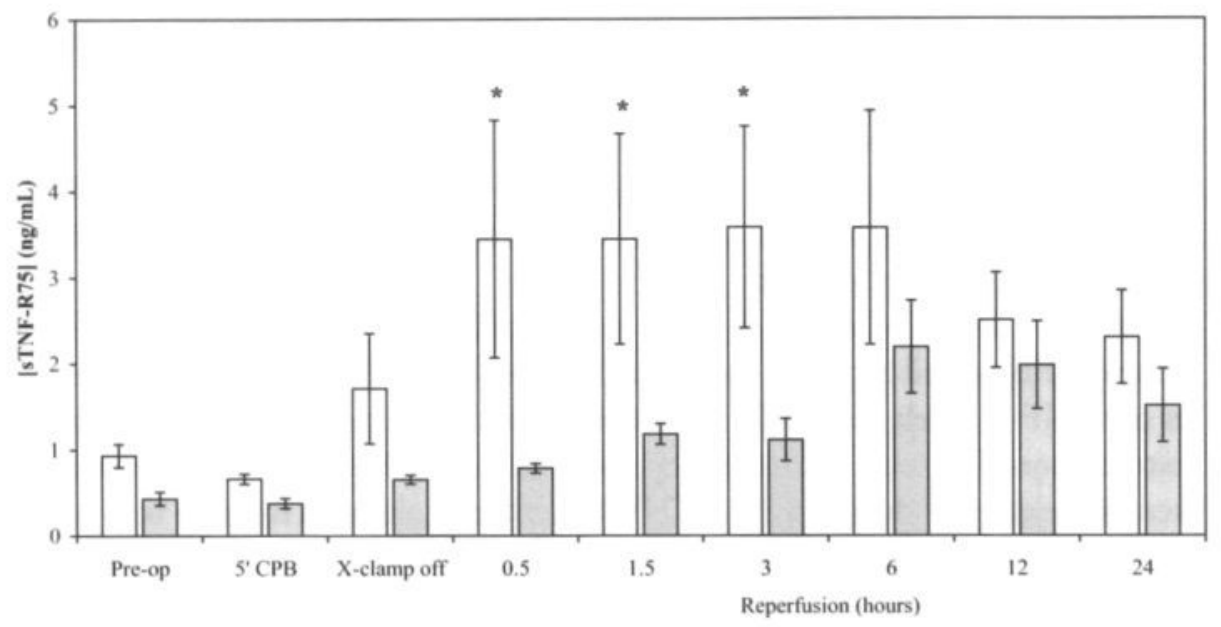

Figure 4 Circulating plasma levels of soluble TNF-R75, mean ( \pm standard error) in patients who underwent $\mathrm{CPB}$ with coated (cross-hatched bars) and non-coated (bars) circuits. Statistically significant differences $(P<0.05)$ between the groups are indicated with an asterisk. Abbreviations as in Figure 1.

\section{sICAM and sE-selectin}

Wide variations in preoperative plasma sICAM levels (ranging from 80 to 442 $\mathrm{ng} / \mathrm{ml}$ ) were found in patients who underwent CPB without heparin-coated extracorporeal circuits (group B). After aortic crossclamping sICAM levels fell immediately to $70 \pm 12 \mathrm{ng} / \mathrm{ml}$. In group A only a modest decrease was demonstrated (from $73 \pm 9 \mathrm{ng} / \mathrm{ml}$ to $54 \pm 7 \mathrm{ng} / \mathrm{ml}$ ). There was no increase in sICAM levels during the initial hours of reperfusion in either group. Twenty-four hours after CPB, the plasma level of sICAM increased in both groups (group A: $107 \pm$ $14 \mathrm{ng} / \mathrm{ml}$, group B: $103 \pm 17 \mathrm{ng} / \mathrm{ml}$ ).

During surgery and subsequently during early reperfusion circulating E-selectin levels showed a tendency to decrease without reaching a level of significance (Figure 5). Later during reperfusion a gradual though profound increase was observed in both groups with peak values between 12 and 24 hours of reperfusion. In patients with a non-coated circuit these peak levels were significantly higher $(P<0.05)$ as compared to the patients treated with the coated circuits (group A: $40 \pm 13 \mathrm{ng} / \mathrm{ml}$, group B: $54 \pm 17 \mathrm{ng} / \mathrm{ml}$ at 12 hours after reperfusion). 


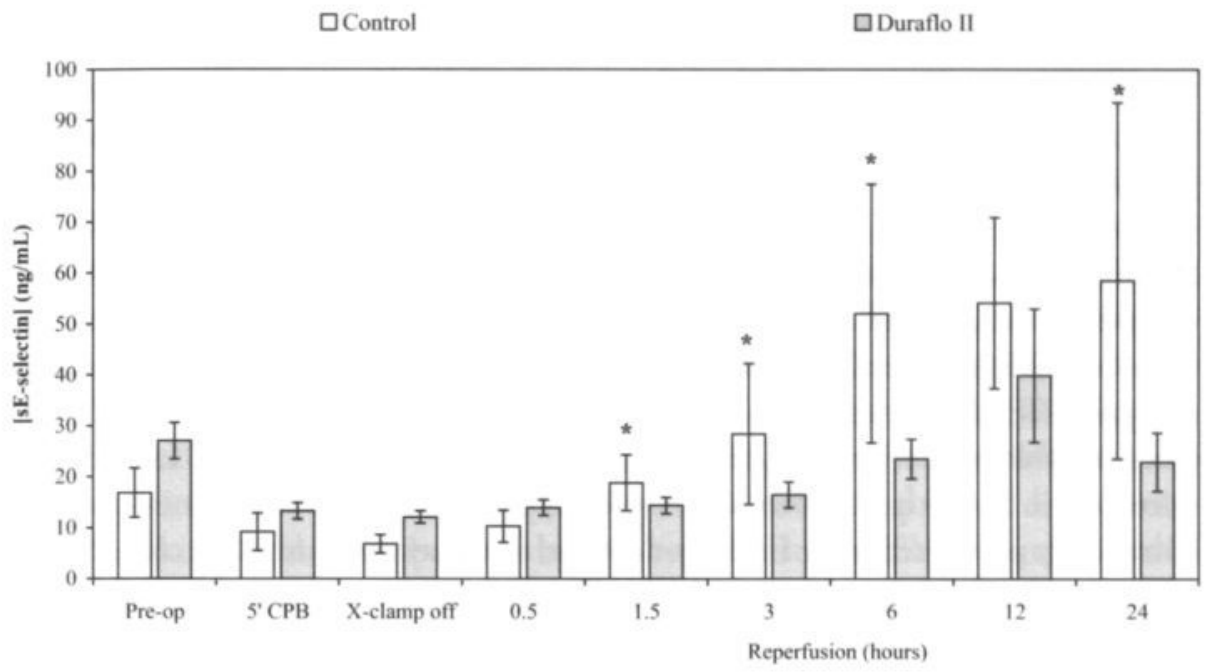

Figure 5 Circulating plasma levels of soluble E-selectin, mean ( \pm standard error) in patients who underwent $\mathrm{CPB}$ with coated (hatched bars) and non-coated (cross-hatched bars) circuits. Statistically significant differences $(P<0.05)$ between the groups are indicated with an asterisk. Abbreviations as in Figure 1.

\section{DISCUSSION}

$\mathrm{CPB}$ for cardiac operations is often associated with bleeding complications and generation of a systemic inflammatory response, which have been related to systemic heparinization and blood cell activation, activation of the coagulation system, fibrinolytic disorders and complement activation $[25,78,92-94]$. The exposure of blood to surfaces in the extracorporeal circuits might contribute to the generalized inflammatory response. Attempts to improve the biocompatibility of the circuits to reduce the systemic reactions have included endothelial cell seeding, heparin-like biomaterials and heparin surface coating $[98,151]$.

Comparison of heparin-coated and uncoated extracorporeal circuits during CPB has shown no significant reduction in platelet activation, fibrinolysis, postoperative blood loss, and donor blood transfusions in routine coronary bypass operations $[11,39]$. The only established and consistent clinical effect of heparin-treated circuits is that it allows perfusion with less systemic heparin in selected patients. This may result in improved hemostasis and reduced blood loss and transfusion requirements [45]. Moreover, a significant reduction of C3 activation products using heparin-coated extracorporeal circuits during $\mathrm{CPB}$ has been described [35]. In the present study we demonstrated that the use of Duraflo II 
heparin-treated extracorporeal circuits reduces the systemic inflammatory reaction during routine $\mathrm{CPB}$ procedures as measured by plasma levels of inflammatory mediators.

In agreement with previous studies [152,153] increased plasma IL-8 levels in patients undergoing CBP without heparin-coated extracorporeal circuits were observed (see figure 2). IL-8 which is produced by monocytes, macrophages, fibroblasts and vascular endothelial cells following stimulation with TNF- $\alpha$, IL-1 or lipopolysaccharide [154], is considered to be an important and early mediator of neutrophil-mediated inflammatory reactions as it strongly attracts neutrophils and enhances their activation. The use of a heparin-coated tubing system showed a remarkable reduction in circulating IL-8 levels. An increase of IL-8 did not occur until 3 to 6 hours after the end of bypass. Since this intervention almost completely prevented early IL-8 production, one may conclude that contact activation might be a major cause of proinflammatory activation in comparison to rewarming, reperfusion or protamine supply as has been suggested by Finn and associates [153].

Trace amounts of TNF- $\alpha$ were found in a few patients in the present study, whereas in most patients and at most time intervals the TNF- $\alpha$ concentration was below the level of detection. In recent studies similar results were obtained [153]. Because TNF- $\alpha$ has a very short half-life in the circulation, frequent serial measurements would be necessary in order to evaluate the precise role, if any, of TNF- $\alpha$ after CPB. Measurement of TNF- $\alpha$-induced factors with slower kinetics may offer an opportunity to indirectly assess the role of TNF- $\alpha$ in the inflammatory response after $\mathrm{CPB}$.

TNF- $\alpha$ and inducers of TNF- $\alpha$ have been shown to cause shedding of TNF-R [155-157]. Therefore, enhanced levels of sTNF-R may reflect a TNF- $\alpha$-induced inflammatory response. However, sTNF-R levels were also shown to be dependent on renal function [158]. In the present study, increases in levels of both sTNF-R were found following CPB. Moreover, in patients with heparin-coated circuits the increase of sTNF-R was significantly delayed. Because renal function of the two groups was not different (data not shown), these data suggest that heparin coating prevents onset of an early inflammatory response during CPB. Many cell types in response to IL- 1 and TNF- $\alpha$ produce IL- 6 . It may be the main inducer of the acute-phase response to injury, and has been shown to be elevated following major surgery reaching peak levels 24 hours after operation $[159,160]$. Here, IL- 6 levels peaked as early as $1 \frac{1}{2}$ hour after the release of the cross clamp and returned towards normal values within 12 hours in patients treated with uncoated circuits. The underlying reason of these differences in kinetics remains unclear but may be dependent on the kind of trauma, medication or the presence of neutralizing proteins like IL- 6 receptors. Heparin coating of the extracorporeal 
circuit significantly attenuated systemic IL-6 levels. Whether this is associated with an attenuated acute-phase response remains to be established.

The soluble adhesion molecule E-selectin increased above baseline starting 3 to 6 hours after cross-clamping time in both groups whereas only a modest increase in sICAM-1 was observed 24 hours after CPB. E-selectin is only found on activated endothelium. E-selectin interacts with carbohydrate ligands and mediates the initial rolling of leukocytes on the endothelium. Endothelial cells have been shown to release E-selectin following in vitro stimulation [147]. Therefore, specific elevations in levels of $s \mathrm{E}$-selectin would indicate activation or damage to endothelium. The presence of higher levels of sE-selectin at 12 hours after CPB suggests that a more pronounced endothelial inflammatory reaction occurred with the non heparin-coated circuits. ICAM-1 is constitutively expressed on vascular endothelial cells and a number of other cell types including fibroblasts, epithelial cells and peripheral blood mononuclear cells and is particularly involved in the firm attachment and transendothelial migration of leukocytes [161]. Its expression is upregulated following activation during an inflammatory response. In vitro studies have shown a direct correlation between the expression of sICAM-1 on endothelial cells and the subsequent shedding of sICAM-1 in the supernatant [147]. The ligand for sICAM-1 on the leukocyte surface is CD18. This CD18 expression increases when leukocytes are stimulated and can be used as a sensitive index of leukocyte activation. In a previous study [36], increased CD18 expression on neutrophils and concomitant neutropenia after 60 minutes of CPB was found. Heparin coating did not change the CD18 expression and neutropenia. The initial drop in circulating sICAM-1 in patients who underwent CPB with the uncoated circuits suggests an increase in activated leukocytes as ligand binding by activated leukocytes may clear sICAM-1 from the plasma. On the other hand, CD18 positive leukocytes are immediately trapped by the vascular endothelial cells and are thus withdrawn from the circulation. Immunohistochemical studies are necessary to elucidate this point of discussion.

In conclusion, this study demonstrates that heparin coating of the extracorporeal circuit can significantly reduce the systemic inflammatory reaction caused by $\mathrm{CPB}$. It is conceivable that the heparin-coated surface exerts its protective effect by modifying mediators of the inflammatory cascade rather than from a direct interaction of heparin coating and coagulation or fibrinolysis. A large clinical study is in progress to provide evidence that postoperative morbidity correlates with proinflammatory activity.

\section{Acknowledgment}

We thank Mrs. Gaby Schoen for her skillful assistance in performing the enzyme-linked immunosorbent assays. 


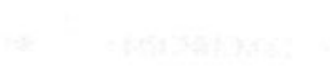

(2) 


\section{CHAPTER 4}

\section{Ex vivo testing of heparin-coated extracorporeal circuits: bovine experiments}

P.W. Weerwind ${ }^{1}$, F.H. van der Veen ${ }^{2}$, T. Lindhout ${ }^{3}$, D.S. de Jong ${ }^{4}$, P.T. Cahalan ${ }^{5}$

${ }^{1}$ Department of Extracorporeal Circulation, University Medical Center Nijmegen, ${ }^{2}$ Departments of Cardiology ${ }^{2}$ and Biochemistry ${ }^{3}$, Maastricht University, ${ }^{4}$ Department of Cardiothoracic Surgery, University Hospital Maastricht, ${ }^{5}$ Bakken Research Center, Maastricht, The Netherlands.

Int J Artif Organs 1998;21:291-298.

Presented at the $13^{\text {th }}$ Biennial Asian Congress on Thoracic and Cardiovascular Surgery, Sydney, Australia, October 10-15, 1997. 


\section{ABSTRACT}

Objective. In this study the intrinsic thrombogenicity of the extracorporeal circuits and the benefit of heparin-bonded circuits in an extracorporeal life support system without full systemic heparinization and with minimal interference of the so-called material-independent factors were tested in four calves.

Methods. In two circuits (group A) all blood-contacting surfaces were coated with end-point-attached heparin and the other two were non-coated (group B). Under standardized conditions the calves were perfused at a blood flow rate of $2 \mathrm{~L} / \mathrm{min}$.

Results. After only one bolus injection of heparin ( $250 \mathrm{IU} / \mathrm{kg}$ body weight) before cannulation, plasma heparin activity rapidly decreased in both groups: half-life of about 55 minutes. This decrease of the heparin activity was accompanied by a fall of the activated clotting time level to baseline values. The experiments using a heparin-coated circuit had a runtime of more than 360 minutes, whereas the experiments using a non-coated circuit had to be terminated after a runtime of 255 minutes, because massive fibrin formation was noticed in the circuit. This formation was accompanied by a rapid increase in the line pressure, measured just before the inlet of the oxygenator. The macroscopic inspections after terminating the experiments and rinsing the circuit showed a clean circuit in group A. The fibrinopeptide A level increased faster during perfusion with the non-coated circuit than in the heparin-coated circuit. Histopathological examinations of the lungs of the animals in group A showed no fibrin deposition, whereas most of the blood vessels of the lung preparations of the animals in group B were partially or completely occluded with fibrin.

Conclusion. These results suggest that heparin bonding greatly reduces the thrombogenicity of the extracorporeal circuit, and therefore it can reduce the need for systemic heparinization in an extracorporeal life support system. 


\section{INTRODUCTION}

Devices implanted in the cardiovascular system provoke a variety of host responses, some of them clinically significant. Short-term (a few hours) contact of extracorporeal devices with blood during cardiopulmonary bypass for open-heart surgery inevitably causes activation of the complement cascade and the blood coagulation pathway [4-12]. The use of anticoagulant drugs, however, counterbalances the inherently thrombogenic nature of the devices' blood contacting surfaces. However, the thrombotic stimulus is only partially suppressed by high dosages of heparin [24]. Moreover, antithrombotic therapy is not always adequate or possible [24-27]. In addition, long-term contact of devices like ventricular assist devices and extracorporeal life support systems could induce an additional set of problems related to impaired hemostasis and whole body inflammatory response $[6,25,28-33]$. The amount of the systemic anticoagulant should therefore be as low as possible, but significant thrombogenesis must be prevented. Obviously, there is a continuing quest for hemocompatible and non-thrombogenic materials.

Modification of surfaces with bioactive molecules is a promising approach in diminishing the harmful effects of devices to the patients' homeostasis [11,34-43]. The Carmeda BioActive Surface (CBAS) with end-point-attached heparin $[162,163]$ is one of the systems available today. In a recently published paper by Gorman and associates [56] it was, however, demonstrated that heparin-coated circuits used with standard doses of systemic heparin reduced platelet adhesion and improve platelet function, but do not produce a meaningful anticoagulant effect during clinical cardiopulmonary bypass (CPB). In an earlier study we could also not confirm the advantage of using a heparin-bonded extracorporeal circuit during routine clinical CPB procedures [11]. Another recent study showed that in patients undergoing re-operative coronary artery bypass or valve procedures the heparin-coated circuits had no significant clinical benefit over uncoated circuits, when a single crossclamp technique was used and pericardial blood was continuously returned to the circuit [164]. Interestingly, during simulated CPB the level of thrombin generation appeared to be remarkably reduced when a CBAS-coating was used [165].

In this study we examined the thromboresistance of the Carmeda BioActive Surface applied to the entire extracorporeal circuit during six hours of circulatory support in animal experiments after only a single bolus injection of heparin. We note that to achieve clinical benefit from heparin-coated extracorporeal bypass circuits, several changes may be required in the way $\mathrm{CPB}$ is performed. A number of studies $[73,82]$ have now clearly demonstrated that not returning pericardial blood to the systemic circulation, limiting heart and lung re-perfusion injury and using specific priming solutions may significantly suppress the massive throm- 
botic stimulus. It was the aim of this study to elucidate the intrinsic thrombogenicity of the extracorporeal circuits and the benefit of heparin-bonded circuits in an extracorporeal life support system without full systemic heparinization and with minimal interference of the so-called material-independent stimuli.

\section{EXPERIMENTAL PROCEDURES}

\section{Animals}

Four calves with a bodyweight of $103 \pm 17 \mathrm{~kg}$ were divided in two groups. In group A $(n=2)$ a heparin-bonded extracorporeal circuit (Carmeda BioActive Surface, Medtronic Cardiopulmonary, Anaheim, CA) was used and in group B $(n=2)$ a similar non-coated extracorporeal circuit was used. The animals received standard premedication with atropine, and anesthesia was induced with thiopental sodium. After endotracheal intubation, volume controlled ventilation with positive end-expiratory pressure of $5 \mathrm{~cm} \mathrm{H}_{2} \mathrm{O}$ was provided. Anesthesia was maintained with halothane, nitrous oxide and thiopental sodium. The experiments were approved by the animal welfare committee of the Maastricht University.

\section{Extracorporeal life support system}

The experimental design is shown in Figure 1. A $9.0 \mathrm{~mm}$ Biomedicus venous cannula was inserted into the right internal jugular vein of the experimental animal. This cannula drained the venous blood by gravity to a collapsible reservoir (MVR-1600, Medtronic, Anaheim CA, USA). Then the blood was pumped (Stöckert roller pump, Stöckert, Münich, Germany) through a Maxima hollow-fiber membrane oxygenator (Medtronic) and returned to the animal via a $6.3 \mathrm{~mm}$ Biomedicus arterial cannula in the right common carotid artery. In group A, all components that contacted blood were completely coated with heparin-bonded Carmeda Bioactive Surface. Prior to the experiment, the extracorporeal circuit was primed with $1500 \mathrm{ml}$ of Haemaccel solution $3.5 \%$ (Behringwerke AG, Marburg, Germany) without heparin.

\section{Partial bypass}

Before connection of the extracorporeal life support system for partial bypass, the calves in both groups received $250 \mathrm{IU} / \mathrm{kg}$ body weight of heparin (Leo Pharmaceutical Products BV, Weesp, The Netherlands) intravenously as a bolus injection. This systemic heparinization was the only heparin administered during the 


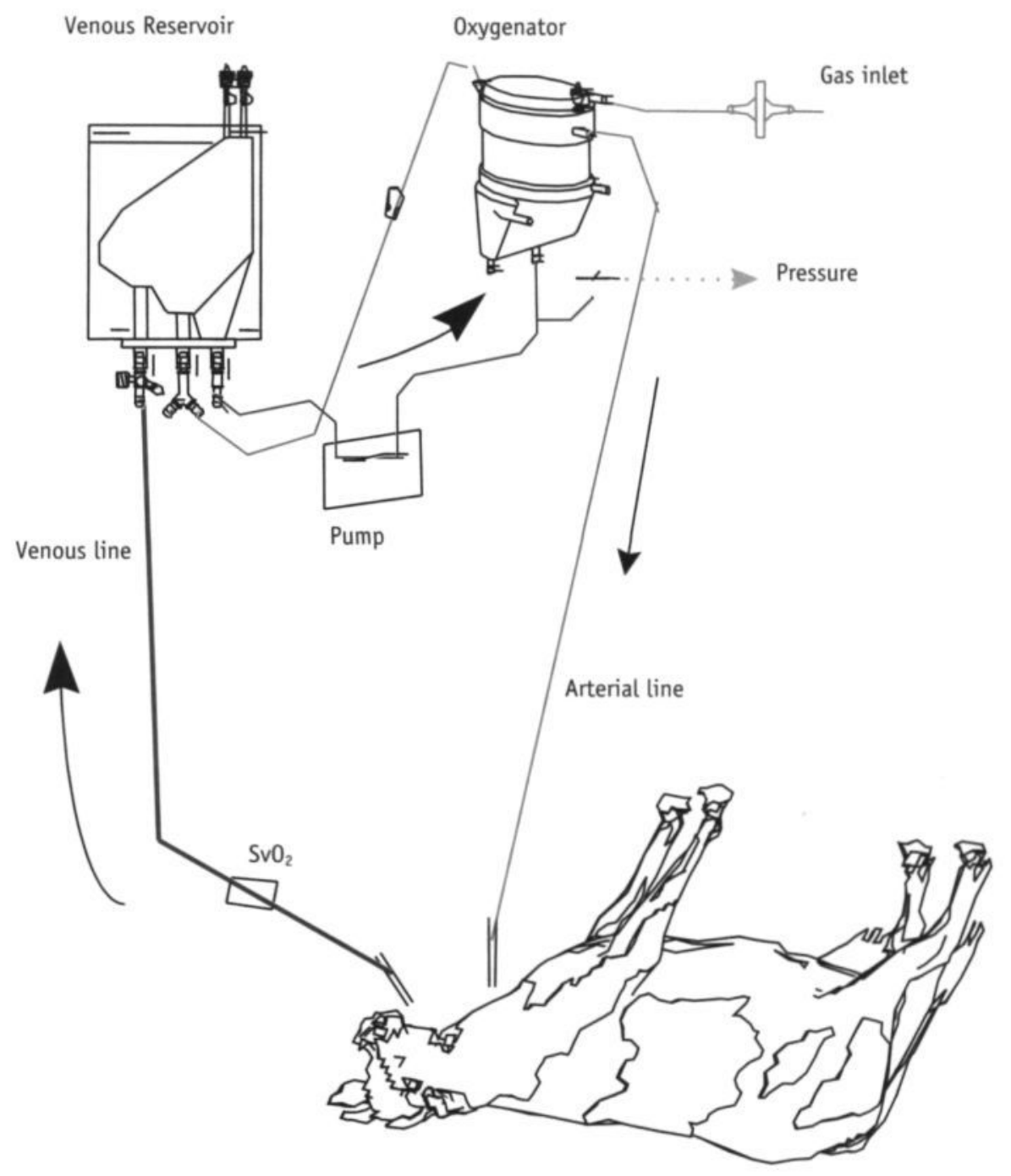

Figure 1 Schematic representation of the extracorporeal circuit. $\mathrm{SvO}_{2}$ indicates venous oxygen saturation. 
total perfusion time in both group A and group B. Partial bypass was initiated in a standardized fashion and under normothermic conditions. To standardize the experiments, the blood flow was maintained constant at $2 \mathrm{~L} / \mathrm{min}$ during the entire perfusion. The mean gas flow rate was $2.5 \mathrm{~L} / \mathrm{min}$ (dry air and oxygen). The experiments were terminated when the oxygenators were occluded by clot formation.

\section{Measurements}

The perfusion pressure at the inlet of the oxygenator was monitored continuously to observe occluding tendencies. Other parameters such as electrocardiogram, central venous pressure, arterial pressure, arterial blood and rectal temperature were monitored online. Cardiac output (thermodilution), and pump flow were recorded at regular intervals. Blood samples were taken before induction of anesthesia, before and after a bolus injection of heparin, after 10 minutes of bypass and every 30 minutes until 360 minutes of bypass for blood gas analyses and for biochemical, hematological and coagulation studies.

Heparin. Five $\mathrm{ml}$ of blood was collected in $0.5 \mathrm{ml}$ of $3.8 \%$ (w/v) trisodium citrate. Heparin was determined in the plasma samples using the Coatest LMW-Heparin/Heparin kit (Chromogenix AB; Mölndal, Sweden). Briefly, $8 \mu \mathrm{l}$ of plasma was mixed with $65 \mu \mathrm{l} \mathrm{S} 2732(2.9 \mathrm{mM})$ and $65 \mu \mathrm{l} \mathrm{FXa}\left(1 \mathrm{nkat} \mathrm{ml}^{-1}\right)$. After 8 minutes at room temperature the reaction was stopped by the addition of $65 \mu \mathrm{l}$ acetic acid $(20 \% \mathrm{~V} / \mathrm{V})$. p-Nitroanilline was measured at $405 \mathrm{~nm}$ in a microtiterplate reader (SLT-reader 340 ATTC). A reference curve was constructed with known amounts of heparin.

The activated coagulation time (ACT) was measured on the Automated Coagulation Timer II device (Medtronic Hemotec, Inc. Anaheim, CA, USA). The high range heparinase test cartridge was used for ACT measurements. In one channel ACT was measured in an untreated blood sample and in the other channel heparinase was added to the blood sample to eliminate heparin (up to $6 \mathrm{U} / \mathrm{ml}$ ). The latter data can be used to detect heparin-independent change in the haemostatic system, such as consumption of blood coagulation factors.

Fibrinopeptide A (FPA). Blood ( $5 \mathrm{ml}$ ) was collected in $0.5 \mathrm{ml}$ of an aqueous solution containing $0.9 \% \mathrm{NaCl}, 500 \mathrm{IU}$ heparin and $500 \mathrm{KIU}$ trasylol. Plasma was prepared by centrifugation at $2000 \mathrm{~g}\left(4^{\circ} \mathrm{C}\right)$ for 10 minutes and at $12000 \mathrm{~g}$ for $10 \mathrm{~min}\left(4^{\circ} \mathrm{C}\right)$. The plasma was then stored at $-80^{\circ} \mathrm{C}$ until analysis. FPA was determined in plasma using the Stago-asserochrom FPA-ELISA kit (Boehringher Mannheim GmbH, Diagnostica) according to instructions.

Cell count. Blood $(2.5 \mathrm{ml})$ was collected in $0.06 \mathrm{ml}$ of $7.5 \%(\mathrm{w} / \mathrm{v})$ tri-potassium EDTA (Sherwood medical vacutainer). Cell counts were performed with the Microdiff 18 Coulter (Coulter Corporation, USA). Bovine platelets' count 
was measured differently because red blood cells give an overlap with platelet settings. Therefore, the red cells were separated from the platelets with a hematocrit centrifuge in a glass capillary $(50 \mu \mathrm{l}$ and ID $=0.0458 \mathrm{~cm}$; EM-Hirschmann, Germany). The capillary was first filled with thrombocyte-oil $(13 \mu \mathrm{l})$ and then with blood $(26 \mu \mathrm{l})$. The red blood cells will be centrifuged through the oil. The oil-blood interface contains small amounts of red and white blood cells. The supernatant above the oil contains the platelets. After centrifugation platelets were counted in the supernatant with the Microdiff 18 Coulter.

Biopsy specimen. Immediately following sacrifice of the experimental animal, biopsy specimen was obtained from lung tissue. Tissue pieces of about $1 \mathrm{~g}$ were fixed in $5 \%$ buffered formalin for at least 24 hours. Subsequently, the tissue was embedded in paraffin and $5 \mu \mathrm{m}$ thin slices were stained for histological analyses. Staining with Hematoxylin Eosin, MSB (Martius yellow brillant Scarlet methyl Blue) and elastin von Gieson were performed to identify the presence of microthrombi, fibrin remnants and to identify different cell types.

\section{RESULTS}

\section{Plasma heparin levels and ACT values}

The data depicted in Figure 2 shows the clearance of heparin from the circulation in both group A as group B, after a single bolus injection of heparin. The plasma heparin concentration decreased significantly in both groups (half life time of about $55 \mathrm{~min}$ ) to an end level of $0.07 \mathrm{IU} / \mathrm{ml}$ at 270 minutes in group $\mathrm{A}$ and 0.10 $\mathrm{IU} / \mathrm{ml}$ after 240 minutes in group B.

The ACT values showed a similar pattern as the heparin concentration. After 180 minutes (group A) and 240 minutes (group B) of partial bypass no significant difference $(P<0.05)$ were observed between the ACT values in the presence and absence of heparinase, indicating the absence of heparin activity. However, the anti-Xa activity at the above time points was still $0.1 \mathrm{IU} / \mathrm{ml}$.

\section{Plasma FPA levels}

The start FPA levels were at the same level $(2 \mathrm{nM})$ in both groups (Figure 3). After a runtime of 150 minutes, the FPA plasma levels started to increase and remained at a value of approximately $4.5 \mathrm{nM}$ FPA in group A. The plasma heparin concentration was at that time point almost zero. In group $B$, the FPA plasma levels started to increase earlier (after a runtime of 60 minutes) and reached a FPA level up to $9 \mathrm{nM}$ at the time the partial bypass was terminated (after a runtime of 255 minutes), because the oxygenator was completely occluded with fibrin clots. 

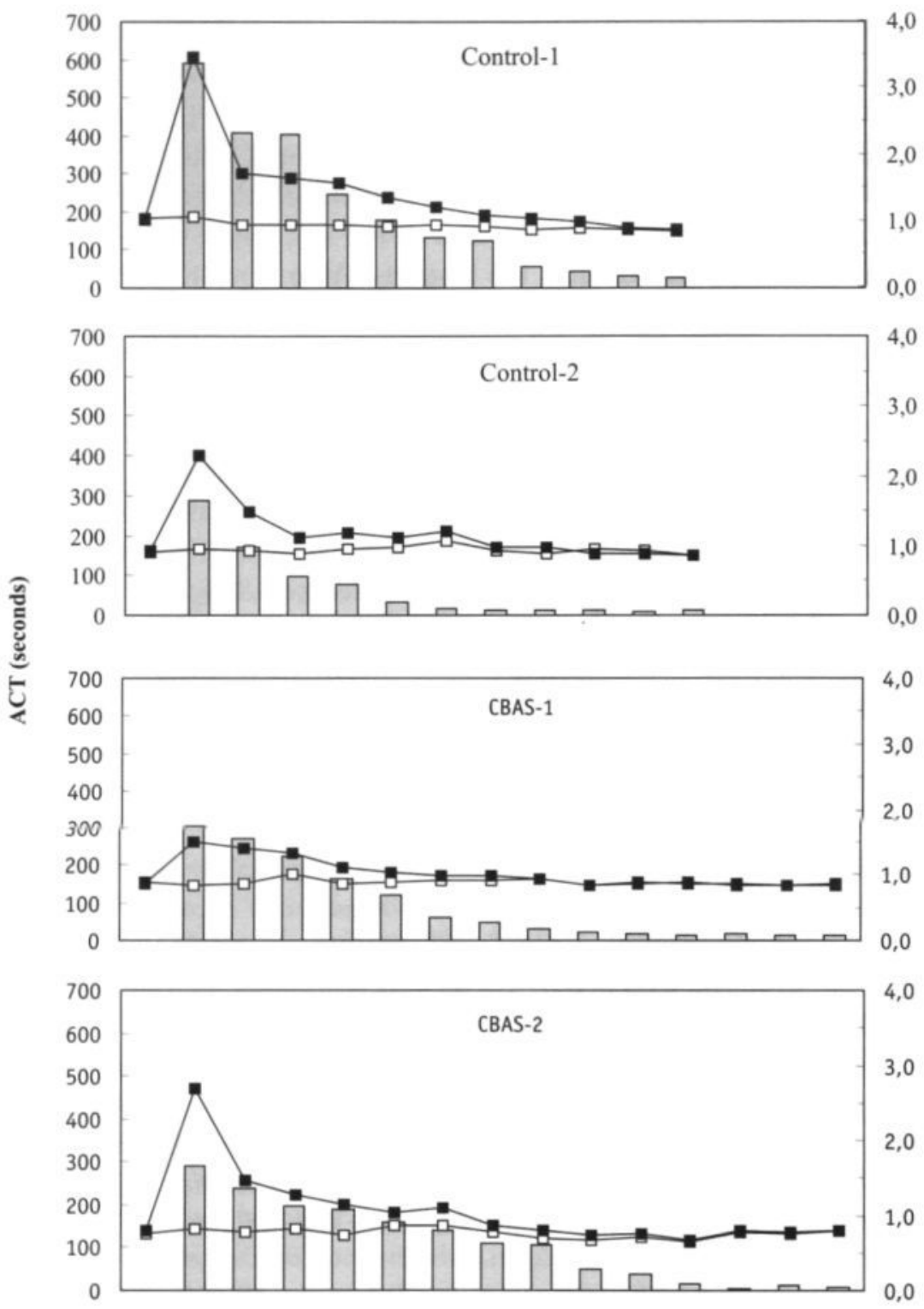

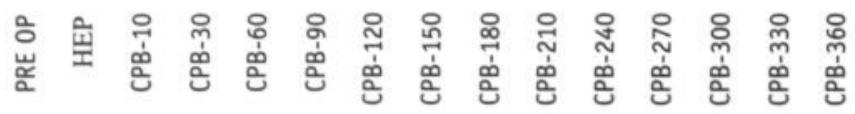

Figure 2 Heparin concentrations and ACT values in calves undergoing partial CPB. The circuits were coated with CBAS (CBAS-1 and CBAS-2) or non-coated (Control-1 and Control-2). The bars represent the heparin concentration measured as anti-Xa activity, the open squares represent the ACT measured in the presence of heparinase and the closed squares the ACT measured in the absence of heparinase. PRE OP indicates preoperative; HEP: 5 minutes after heparin administration, but before CPB; CPB-0, CPB-10, etc: minutes after the start of CPB. 


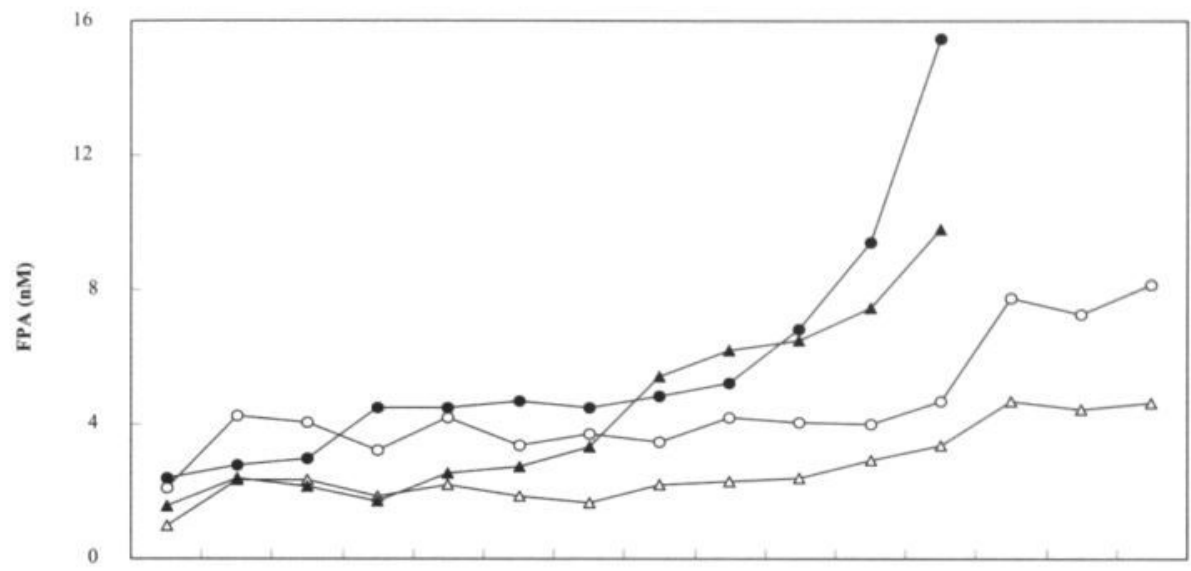

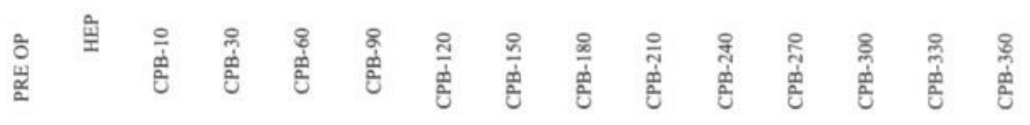

Figure 3 Changes in FPA during partial CPB with CBAS-coated circuit (open triangles: CBAS-1 and open circles: CBAS-2) and with non-coated circuits (closed circles: Control-1 and closed triangles: Control-2). PRE OP indicates preoperative; HEP: 5 minutes after heparin administration, but before CPB; CPB-0, CPB-10, etc: minutes after the start of CPB.

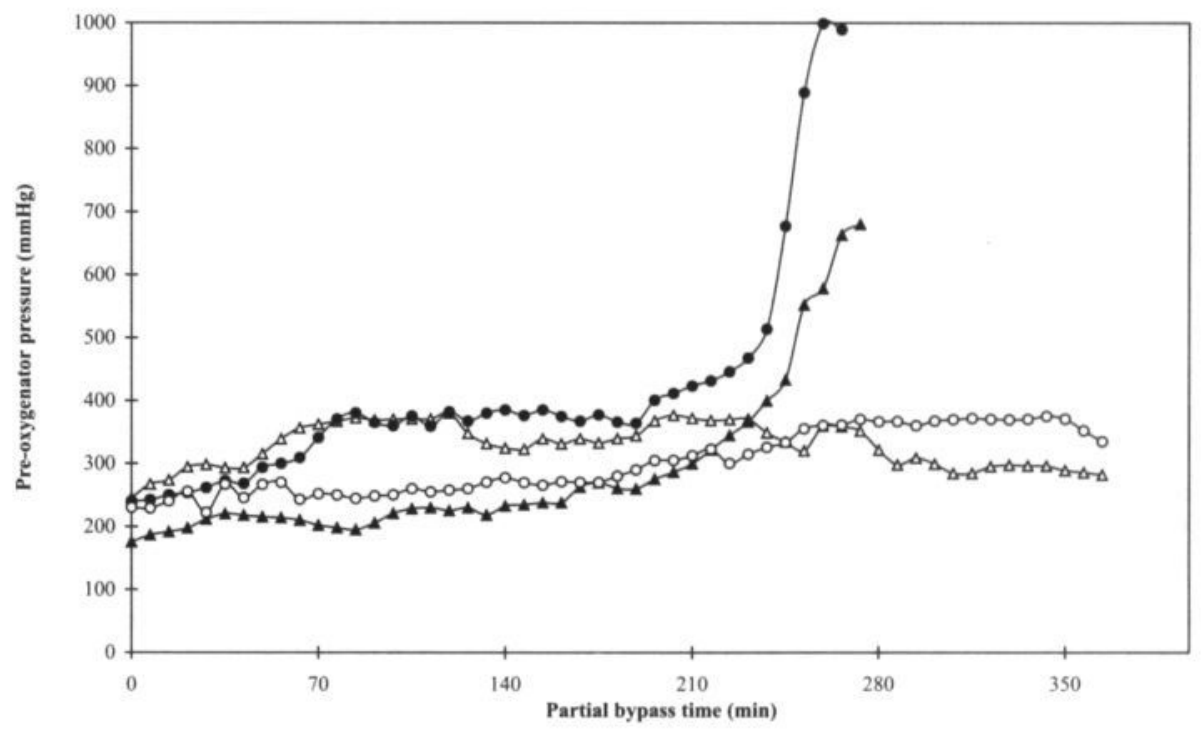

Figure 4 Changes in pre-oxygenator pressures during partial CPB with CBAS-coated circuit (open triangles: CBAS-1 and open circles: CBAS-2) and with non-coated circuits (closed circles: Control-1 and closed triangles: Control-2). 

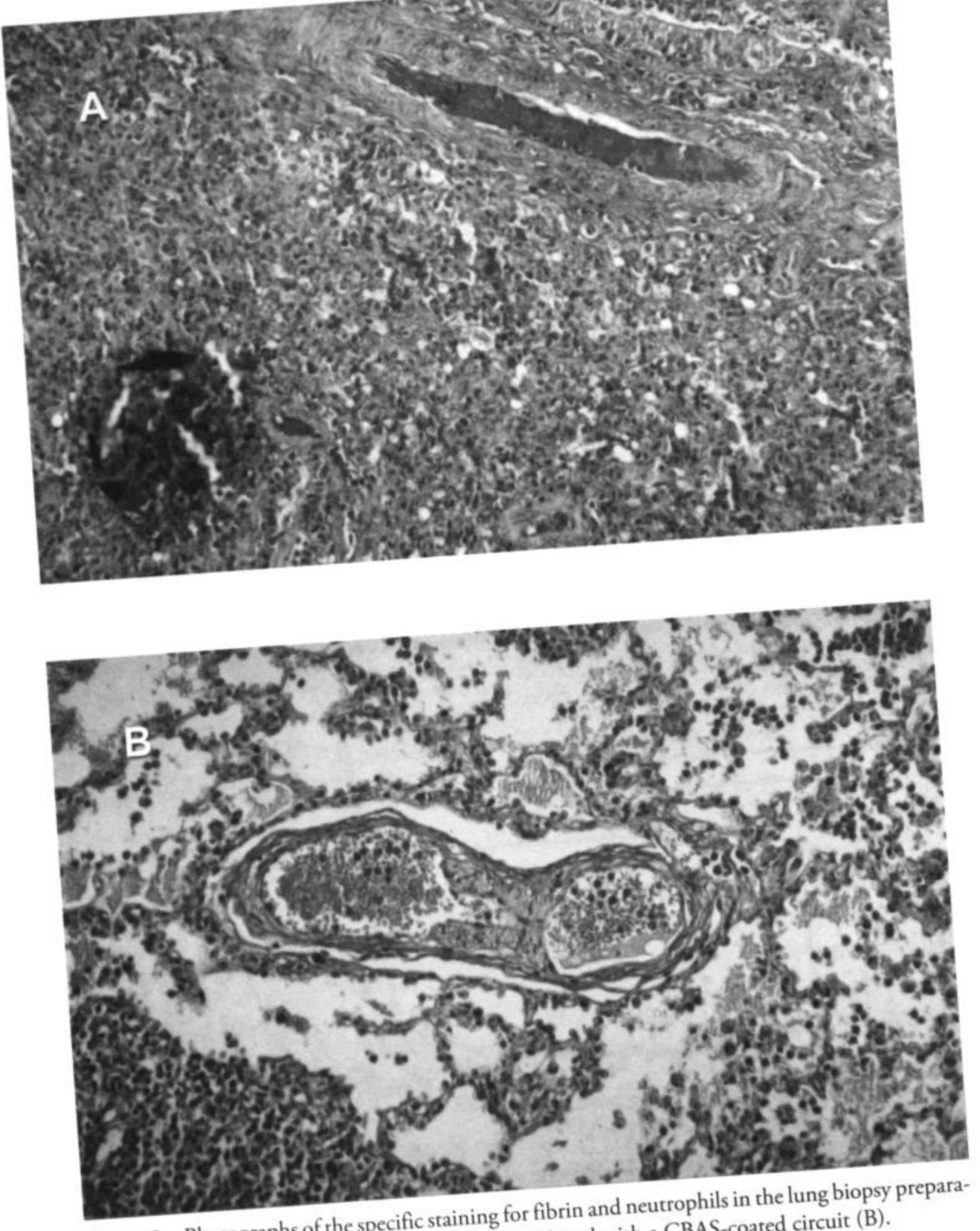

Figure 5 Photographs of the specific staining for $(A)$ and with a CBAS-coated circuit (B) tion of calves perfused with a non-coated circuit (A) and wirh a 


\section{Pre-oxygenator pressure}

The pre-oxygenator pressure in both groups showed some fluctuations probable due to unstable hemodynamics of the experimental animals (Figure 4). In group $\mathrm{B}$ a dramatic increase in pre-oxygenator pressure was noticed after a runtime of $195 \mathrm{~min}$. The experiment was stopped after a runtime of 255 minutes. In contrast to this, the experiments in group A could be run with no complications until the arbitrarily chosen standardized runtime of 360 minutes.

\section{Biopsy of lung tissue}

The specific staining for fibrin (Figure 5A) indicated that most of the blood vessels in the lung preparation of the animals perfused with a non-coated circuit (group B) were partially or completely occluded with fibrin. As in the animals perfused with a CBAS-coated circuit (group A), no fibrin deposition was noticed (Figure 5B). The lung biopsy in both groups showed accumulation of neutrophils.

\section{DISCUSSION}

Modification of surfaces with bioactive molecules seems to be a promising approach in diminishing the harmful effects of devices to the patients' homeostasis [11,34-43]. Because of the well-known side effects of systemically applied heparin, especially during long-term circulatory support, its dosage should therefore be as low as possible, but at the same time significant thrombogenesis must be prevented. During long-term extracorporeal life support, using a heparin-treated circuit with end-point-attached heparin, not only does a reduction in systemic heparin in the blood circulation become possible, but the thrombogenicity of the circuit is greatly reduced too.

Our results in the animal experiments confirm the applicability of endpoint-attached heparin-coated surfaces to long-term extracorporeal circulation. These data confirm and extend the findings of other investigators who also found a reduced thrombogenicity of the circuit during long-term extracorporeal support with limited, or no systemic heparinization [29,30,32,166,167]. In contrast, during an earlier study we could not confirm the advantage of using a heparin-bonded extracorporeal circuit during routine clinical CPB procedures [11]. Gorman and associates [56], and Muehrcke and colleagues [164], have recently demonstrated that heparin-coated circuits used with standard doses of systemic heparin, do not produce a meaningful anticoagulant effect during clinical CPB. Apparently, several changes in the way CPB is performed are likely to be required 
to demonstrate the benefit of heparin-coated circuits during clinical CPB. Not returning pericardial blood to the systemic circulation [73] and reducing systemic heparinization [168-170], limiting heart and lung reperfusion injury, and using specific priming solutions [171-175] may all be needed to elucidate the beneficial effects of heparin-coated circuits. It is likely that these factors allowed biomaterial-independent stimulation of the body's defense system to overwhelm any biomaterial-dependent mitigating properties of heparin-bonded circuits.

Our results also show that a heparin-bonded extracorporeal life support system can be run without any additional systemic heparinization once the initial bolus injection is cleared from the circulation. However, one of the most important requirements for effective application of heparin-bonded circuits is that blood flow is maintained [31-33]. Stagnant areas and drastic lowering of flow rates or even total stoppage of blood flow in the cannulae, for instance were avoided. These are strict limitations in design of the extracorporeal life support systems and should be further investigated. One must also remember that even in an intact blood vessel, stagnation of blood stimulates coagulation.

Besides the limitations in design of the extracorporeal life support systems, another major problem in long-term extracorporeal support are bleeding complications, partly due to the systemic heparinization [28-33,176,177]. The amount of the systemic heparinization should therefore be as low as possible [178], and in an ideal case perhaps it could be fully avoided [31]. In this study we tried a single bolus of $250 \mathrm{IU} / \mathrm{kg}$ body weight of heparin to prevent initial complications. The results clearly show that the plasma heparin activity was completely gone after 210 minutes in group $\mathrm{A}$ and 150 minutes in group $\mathrm{B}$, as indicated by the ACT values that returned to baseline values. The ACT was measured in the presence and absence of heparinase. However, the heparin concentration as assessed by anti-Xa activity, at the above time points was still about $0.1 \mathrm{IU} / \mathrm{ml}$ in group A and B. One could wonder whether a circulating endogenous heparin-like activity remains once exogenous heparin disappears from the circulation.

Despite this very low heparin-like activity no abnormalities were observed in group $\mathrm{A}$, with regards to hemodynamic functions/gas values and acid-base parameters during the entire runtime. In contrast, after 180 minutes macroscopic fibrin formation was noticed in the circuits that were used in group B. This formation was accompanied by a rapid increase in the line pressure, measured just before the inlet of the oxygenator, and as a consequence the experiments in group B had to be terminated after a runtime of 255 minutes. The macroscopic inspections after terminating the experiments and rinsing the circuit showed a clean circuit in group A. In the circuits used in group B, total clotting or extensive clotting occurred with the formation of a granular surface throughout the entire circuit as well as long tails of clotting and embolization. 
The plasma levels of FPA in the experiments in group B showed a profound and steep increase after a runtime of 60 minutes, indicating an immediate activation of the coagulation cascade, which was significantly earlier than in the experiments in group A. The increasing plasma levels of FPA was in accordance with massive clot formation in the circuits that were used in group B. Interestingly, despite the formation of thrombi, no significant reduction in platelet count was measured. In the experiments in group A, a moderate increase was noticed in plasma FPA levels after a runtime of 150 minutes, indicating good thromboresistance of the surface. However, the hemodynamic design and the flow rate are also very important factors in the thromboresistance capacity of the heparin-bonded surface [179].

As a result of the profound activation of the coagulation cascade in the experiments in group B, the blood vessels of the lung biopsy specimen obtained from lung tissue immediately following sacrifice of the animal, were partially or completely occluded with fibrin. No fibrin deposition was seen in the lung preparations of the animals in group A. However, the lung biopsy in both experimental groups showed accumulation of neutrophils. The reason for this accumulation of leukocytes in our animal model is not entirely clear, and needs to be further elucidated. Despite the accumulation of leukocytes in the lung preparations, no additional reduction was noticed in the white blood cell count. A reduction of $30-35 \%$ of the number of platelets, white blood cells and red blood cells was noticed as a result of hemodilution after partial bypass was started in both experimental groups.

In summary, it is concluded that surface heparin bonding has a thromboresistant effect, and therefore it can reduce the need for systemic heparinization in a CBAS-coated extracorporeal life support system. In addition to the measurement of the activated clotting time, with or without heparinase, the measurement of fibrinopeptide A levels may be a valuable test of the clotting activity in the system.

\section{Acknowledgements}

The authors would like to thank Mr. J. Habets, Mr. T. van der Nagel, Mr. R. Blezer, Ms. C. Maassen and Ms. V. Heijnen for their expert technical assistance. 


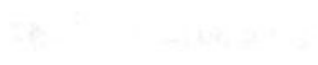

.

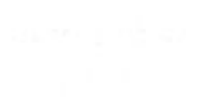

. 


\section{CHAPTER 5}

\section{Exposure of procoagulant phospholipids at the surface of platelets in patients undergoing cardiopulmonary bypass using non-coated and heparin-coated extracorporeal circuits}

P.W. Weerwind ${ }^{1}$, N.E.H. Caberg ${ }^{2}$, C.P.M. Reutelingsperger ${ }^{3}$, T. Lindhout $^{3}$, and D.S. de Jong ${ }^{2}$.

${ }^{1}$ Department of Extracorporeal Circulation, University Medical Center Nijmegen, ${ }^{2}$ Department of Cardiothoracic Surgery / Extracorporeal Circulation, University Hospital Maastricht, ${ }^{3}$ Department of Biochemistry, Maastricht University, The Netherlands. 


\section{ABSTRACT}

Objective. Cardiopulmonary bypass (CPB) is associated with a generalized hemostatic defect, in which platelet dysfunction seems to play a central role. The present study was designed to elucidate whether the potential procoagulant activity of platelets, detected as annexin $\mathrm{V}$ binding, was altered during coronary bypass surgery, using non-coated and heparin-coated extracorporeal circuits.

Methods. Thirty patients undergoing elective coronary artery bypass grafting were prospectively randomized using either a standard untreated extracorporeal circuit $(n=15)$ or a heparin-treated extracorporeal circuit $(n=15)$. Beside measurement of the procoagulant phospholipid activity, the mediastinal blood loss after surgery, and the blood transfusion requirements were also monitored.

Results. CPB induced a decrease in the percentage of activated platelets in whole blood, manifest directly after start of CPB, which was significantly attenuated using a non-treated system. Postoperative the percentage of activated platelets recovered in both systems, reaching a point of significance 24 hours after the operation, compared to the values 2 hours after the operation. The differences among the groups for mediastinal blood loss during the first 2 and 24 hours postoperative coincided with the differences in procoagulant phospholipid activity. Furthermore, there was no statistical difference among the groups for blood transfusion requirements. The platelets in both groups showed a significantly lower ability to generate ionomycin-induced procoagulant activity after bloodmaterial interaction when compared to the baseline values.

Conclusion. These observations are compatible with the notion that during CPB, irrespective of the heparin coating, platelets become modestly activated and are then rapidly removed from the circulation. 


\section{INTRODUCTION}

The use of $\mathrm{CPB}$ during cardiac surgery is associated with activation of cellular blood components $[78,112,180-186]$, which can be harmful for the patient by jeopardizing his morbidity during recovery of his surgical treatment. Although the clinical manifestations of cellular injury are typically mild in short-time CPB, during longer bypass times excessive blood loss and endothelial damage by sequestered leukocytes [187] may result. Possible etiologies for these clinical manifestations include complement activation, enhanced fibrinolysis and depletion of coagulation factors $[78,185,186,188]$, although a central role seems to be played by platelet abnormalities [189-194]. Thus, it is of obvious importance to understand the mechanisms of platelet alterations during $\mathrm{CPB}$ in order to develop strategies to prevent or minimize these changes.

Exposure of blood to materials used in the extracorporeal circuit during $\mathrm{CPB}$ has long been implicated as a source of blood component activation $[7,78,112$, 180-186,195-198]. Consequently, with the introduction and use of heparin-coated extracorporeal circuits, it is of importance to understand the mechanisms by which platelets lose their function and integrity after the biological interface with the surface of the circuit. Some investigators showed that the release of platelet granule products such as $\beta$-thromboglobulin and thromboxane $B_{2}$, when compared with non-coated circuits, were not reduced during routine coronary bypass operations using a heparin-coated extracorporeal circuit $[39,164]$. However, other studies indicate that heparin-coated circuits significantly reduce platelet activation $[7,195,196]$. Research by Gorman and associates [56], however, demonstrated that heparin-coated circuits significantly reduce platelet adhesion and maintained platelet sensitivity to adenosine diphosphate, but did not reduce release of $\beta$-thromboglobulin.

In the present study, the flow cytometry technique was used allowing the examination of large numbers of individual cells for exposure of phosphatidylserine (PS) in the plasma membrane of platelets and the sensitivity of non-PS exposing platelets for ionomycin-induced platelet activation. The aminophospholipid PS is normally restricted to the inner leaflet of the plasma membrane. Cell activation, apoptosis and cell stress can induce redistribution of phospholipids and PS becomes rapidly exposed in the outer leaflet of the plasma membrane. Concomitant with PS exposure structural changes take place. Among the functions of surface exposed PS are macrophagal recognition $[199,200]$ and modulation of proinflammatory and prothrombotic effects of platelets [201].

The aim of this study was to elucidate whether the procoagulant activity of platelets was altered during coronary bypass surgery, using non-coated and heparin-coated extracorporeal circuits. 


\section{MATERIALS AND METHODS}

\section{Patients}

Thirty adult patients, subsequently undergoing elective coronary artery bypass grafting were enrolled in this study. The patients were randomly divided into two groups. The patients in group A $(n=15)$ were perfused with our standard noncoated extracorporeal circuit, whereas the patients in group $B(n=15)$ were perfused with a heparin-coated (Duraflo ${ }^{\otimes}$ II, Baxter Bentley Inc., Irvine, CA, USA) circuit.

Exclusion criteria were the following: previous cardiac surgery, congestive cardiac failure, neurological disorders (e.g. cerebrovascular accident), severe pulmonary disorders (e.g. chronic obstructive pulmonary disease, emphysema), insulin/non-insulin dependent diabetics, renal diseases (e.g. renal failure), liver diseases, preoperative coagulopathies and platelet-inhibiting drugs five days before the operation. Moreover, patients receiving intravenous heparin therapy preoperative were also excluded from the study.

Informed consent was obtained from each patient the day before the operation. The study was approved by the local ethical and research council.

\section{Anesthesia}

After premedication with lorazepam, anesthesia was induced by fentanyl citrate and midazolam hydrochloride; muscle relaxation was achieved with pancuronium bromide. Analgesia was provided by alfentanil hydrochloride and midazolam hydrochloride infusion. Cefuroxim was used for antibiotic treatment, and the first dose was administered before sternotomy. Before connection of the extracorporeal circuit for CPB, heparin (300 IU/kg Heparin Leo, Leo Pharmaceutical Products BV, Weesp, The Netherlands) was administered in order to achieve an activated coagulation time (ACT) > 480 seconds (Hemotec ACT II, Medtronic Inc., Anaheim, CA, USA).

\section{Cardiopulmonary bypass}

The main components in the extracorporeal circuit consisted of a hollow fiber membrane oxygenator (in group A: Capiox SX-18, Terumo Corporation, Tokyo, Japan; in group B: Spiral Gold, Baxter Bentley Inc., Irvine, CA, USA.), a venous reservoir (BMR-1900. Baxter Bentley Inc.), a cardiotomy reservoir (in group A: William Harvey H4700, C.R.Bard Inc., Tewsbury, MA, USA; in group B: BCR-3500 Gold; - Baxter Bentley Inc.), and an arterial line filter (in group A: Pall autovent SV, Pall Biomedical Ltd, Portsmouth, UK; in group B: AF 1040 
Gold, Baxter Bentley). In group B, all components exposed to blood were pretreated with a heparin-bonded coating (Duraflo'II, Baxter Bentley Inc.). The standard priming of the extracorporeal circuit was $1300 \mathrm{ml}$ Haemaccel $3.5 \%$ (Behringwerke AG, Marburg, Germany), $200 \mathrm{ml}$ Mannitol 20\%, $100 \mathrm{ml}$ Human-Albumin 20\%, $50 \mathrm{ml} \mathrm{NaHCO} 38.4 \%, 20 \mathrm{ml} \mathrm{KCl} \mathrm{7.45 \%} \mathrm{(B.Braun}$ Medica BV, Uden, The Netherlands) and 6500 IU Heparin Leo.

Moderate hypothermia (from 28 to $30^{\circ} \mathrm{C}$ ) and pulsatile perfusion was used throughout the period of aorta crossclamping. During the conduct of $\mathrm{CPB}$ attention was given to restrict, and if possible, to avoid the use of the cardiotomy suction. Additional heparin was administered during bypass if the ACT was lower than 400 seconds. After CPB, heparin was reversed by $3 \mathrm{mg} / \mathrm{kg}$ protamine chloride (Hoffman/Laroche BV, Mijndrecht, The Netherlands). During and after cardiopulmonary bypass no anti-fibrinolytic agent was used.

\section{Blood sampling}

Blood samples were taken before heparin administration (time point 1), 5 and 60 minutes after the beginning of CPB (time point 2 and 3), 15 minutes after protamine administration (time point 4), 2 and 24 hours after surgery (time point 5 and 6). In addition, the mediastinal blood loss within the initial 2 and 24 hours after surgery, and the blood transfusion requirements were also monitored

\section{Measurement of platelet procoagulant activity}

The whole blood samples anticoagulated with acid-citrate-dextrose buffer (ACD) were incubated with $10 \mu \mathrm{g} / \mathrm{ml}$ FITC (fluorescein isothiocyanate) -labeled annexin V (NeXins Research, Kattendijke, The Netherlands) and transferred to a flow cytometric reaction tube that was immediately placed in the flow cytometer (Coulter Epics XL-MCL, Beckman Coulter Inc., Fullerton, Ca, USA). The binding of FITC-annexin $\mathrm{V}$ to procoagulant platelets in the whole blood samples was monitored.

For determination of ionomycin-induced platelet procoagulant activity, platelet-rich plasma was prepared from whole blood samples taken at the above mentioned time points by centrifugation at $1000 \mathrm{~g}$ for 12 minutes. The platelet rich plasma was diluted 50 fold in Hepes buffer $\mathrm{pH} 7.4$ (25 mM Hepes, $140 \mathrm{mM}$ $\mathrm{NaCl}, 2.5 \mathrm{mM} \mathrm{CaCl}$ ), containing $10 \mu \mathrm{g} / \mathrm{ml}$ FITC-labeled annexin $\mathrm{V}$ and transferred to a flow cytometric reaction tube. At time point zero the diluted platelets were stimulated to expose PS by the addition of $10 \mu \mathrm{M}$ ionomycine, as described by Dachary-Prigent et al [202]. The tube was immediately placed in the flow cytometer and the binding of FITC-annexin V to the platelets was monitored continuously in time. The FITC signal versus time plots was analyzed off-line. 
These plots showed a time-dependent increase of FITC-annexin V signal per platelet until a plateau was reached. This plateau reflects the maximum binding capacity of platelets for annexin V and hence maximal amount of PS that can be exposed. From the time required to reach this plateau the velocity of PS exposure could be calculated. Varying the FITC-annexin V between 5 and $20 \mu \mathrm{g} / \mathrm{ml}$ had no influence on the time-course of annexin V-FITC binding to the platelets, indicating that the rate-limiting factor is the rate of PS exposure and not the PS FITC-annexin V interaction.

\section{Statistical analysis}

Before data analysis, to confirm distribution, all the individual sample points were tested according to the chi-square test for data with nominal scaling and Kolmogorov-Smirnov goodness-of-fit test with a normal test distribution for data higher than nominal scaling. The results were expressed as the mean \pm standard error of the mean (SEM), except for the patients' demographics, which is expressed as mean \pm standard deviation. ANOVA with repeated measures was used to analyze sequential measurements over time within one group. The Mann Whitney $U$-test was used for statistical analysis of differences between both experimental groups. A $p$ value of less than 0.05 was considered to indicate a statistically significant difference between measured values.

\section{RESULTS}

\section{Patients' demographics}

Both experimental groups had similar characteristics with respect to gender, age, body weight, and height. Also, bypass time and duration of aortic cross clamping were comparable in both groups (Table 1).

\section{Circulating procoagulant platelets}

Although no significant difference was observed between both experimental groups with regards to the percentage of activated platelets in whole blood during and after the operation, however, in both group $\mathrm{A}$ as group $\mathrm{B}$ an intriguing pattern in time was observed (Figure 1). Before administration of heparin and blood-material interaction (time point 1 ) there was already a small population of activated platelets $(0.49 \pm 0.06 \%$ in group $A$, and $0.58 \pm 0.10 \%$ in group $B)$ present in the patient's blood circulation. As soon as $\mathrm{CPB}$ was started, the percentage of activated platelets significantly decreased in group $\mathrm{A}$ as compared to the base- 
Table 1 Clinical characteristics of the patients groups. Data are presented as mean \pm standard deviation.

$\begin{array}{lccc} & \begin{array}{c}\text { Group A (non-coated) } \\ \mathrm{n}=15\end{array} & \begin{array}{c}\text { Group B (heparin-treated) } \\ \mathrm{n}=15\end{array} & P \text { value } \\ \text { Gender (M / F) } & 13 / 2 & 12 / 3 & >0.20 \\ \text { Age (years) } & 59 \pm 8 & 57 \pm 8 & >0.20 \\ \text { Height (cm) } & 174 \pm 7 & 171 \pm 6 & >0.20 \\ \text { Weight (kg) } & 83 \pm 18 & 78 \pm 10 & >0.20 \\ \text { Aortic crossclamp time (min) } & 56 \pm 16 & 49 \pm 20 & >0.20 \\ \text { Bypass time (min) } & 87 \pm 20 & 79 \pm 25 & >0.20\end{array}$

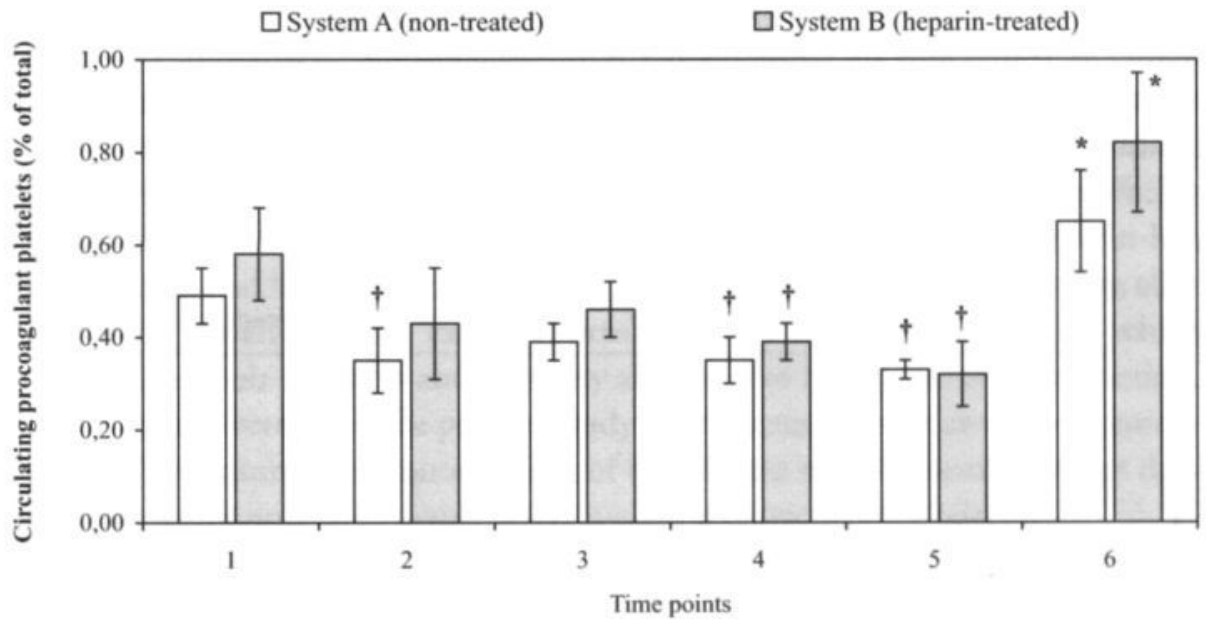

Figure 1 Circulating procoagulant platelets. The percentage of procoagulant platelets in whole blood during CABG, using either a non-treated extracorporeal system (bars) or a heparin-treated extracorporeal system (cross-hatched bars) was determined as described in the text. Data are presented as mean \pm SEM. Cross signs indicate a statistically significant difference compared with time point 1 within one group ( $P<0.05$ by ANOVA for repeated measures); asterisks indicate a statistically significant difference compared with time point 5 within one group $(P<0.05$ by ANOVA for repeated measures).

line value (from $0.49 \pm 0.06 \%$ to $0.35 \pm 0.07 \% ; P=0.04$ ). In contrast, a modest decrease of activated platelets was observed in patients perfused with a heparin-treated extracorporeal system (group B). During the operation the circulating procoagulant platelets showed a tendency to increase, without reaching a level of significance. After neutralization of heparin, again a significant decrease was 
observed in both groups. This decrease of activated platelets sustained 2 hours after the operation. Interestingly, 24 hours after the operation the amount of circulating procoagulant platelets was significantly higher compared to the values 2 hours after the operation (from $0.33 \pm 0.02 \%$ to $0.65 \pm 0.11 \%$ in group $A$; $P=0.04$, and from $0.32 \pm 0.07 \%$ to $0.82 \pm 0.15 \%$ in group $B ; P=0.01$ ).

\section{Ionomycin-induced platelet procoagulant activity}

The time courses of ionomycin-induced annexin $\mathrm{V}$ binding in platelets from group A and B are shown in Figure 2. The maximum exposure of platelet procoagulant activity was significantly decreased in both group $\mathrm{A}$ as group $\mathrm{B}$ after the beginning of CPB (time point 2), as compared to the baseline value (time point 1) of both groups (from $54 \pm 4$ sites to $44 \pm 2$ sites in group $A ; P=0.01$, and from $49 \pm 2$ sites to $43 \pm 2$ sites in group $B$; $P=0.002$ ). These findings suggest that, during blood-material contact a small platelet population become (partially) activated and are consequently removed from the circulation. During the course of the operation and subsequently after surgery the ionomycin-induced platelet procoagulant activity remained significantly decreased in both experi-

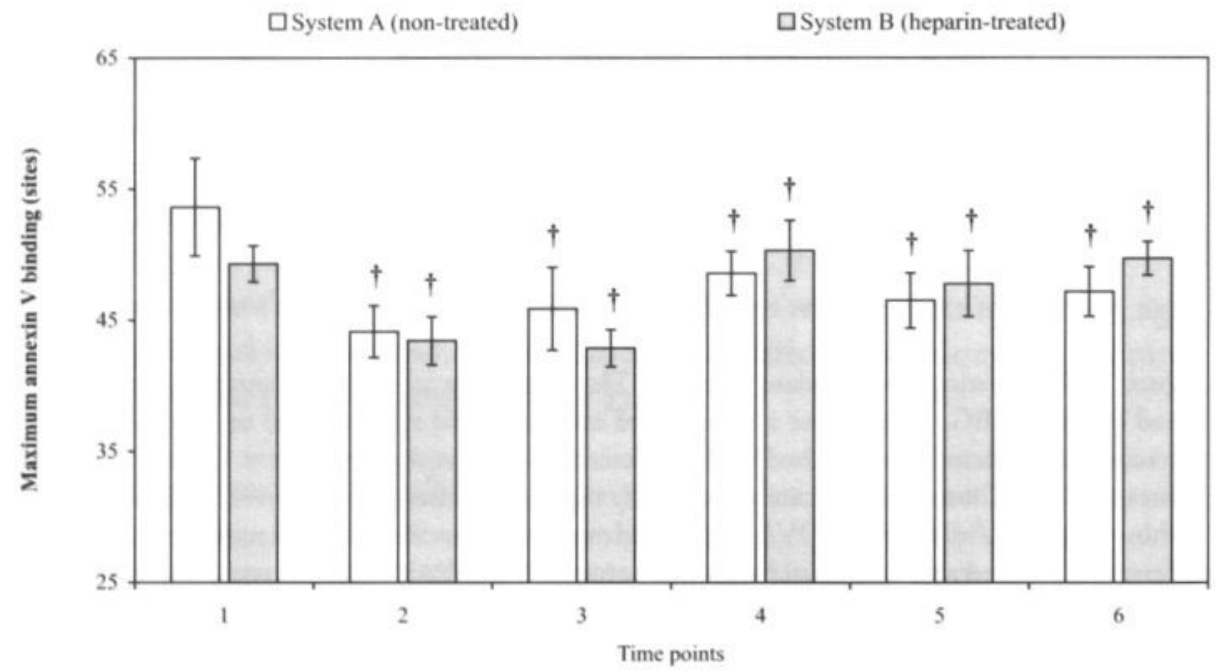

Figure 2 Ionomycin-induced platelet procoagulant activity. The potential platelet procoagulant activity from patients undergoing $\mathrm{CABG}$, using either a non-treated extracorporeal system (bars) or a heparin-treated extracorporeal system (cross-hatched bars) was examined after ionomycin treatment as described in the text. Data are presented as mean \pm SEM. Cross signs indicate a statistically significant difference compared with time point 1 within one group ( $P<0.05$ by ANOVA for repeated measures). 
mental groups. No significant differences in platelet procoagulant activity between both groups were observed at any of the six time points studied.

\section{Postoperative morbidity}

The blood loss from the mediastinal drains within the initial 2 and 24 hours after arrival in the ICU did not show any significant difference between the two experimental groups ( $457 \pm 103 \mathrm{ml} 2$ hours ICU and $1373 \pm 141 \mathrm{ml} 24$ hours ICU in group A versus $335 \pm 59 \mathrm{ml} 2$ hours ICU and $1140 \pm 131 \mathrm{ml} 24$ hours ICU in group $\mathrm{B}$; both $P=0.15)$. Furthermore, there was no statistical difference among the groups for packed red cells usage $(350 \pm 100 \mathrm{ml}$ in group A versus $300 \pm 75$ $\mathrm{ml}$ in group $\mathrm{B} ; P>0.20$ ).

\section{DISCUSSION}

Cardiopulmonary bypass technology is being continuously improved to minimize the adverse biological reactions $[7,78,112,180-186,195-198]$ that are reported to be associated with its use. Attempts to improve the biocompatibility of the circuits to reduce blood cell activation have included heparin-like biomaterials, and heparin surface coating $[98,151]$. However, in spite of the clinical use of heparin-coated extracorporeal circuits, the mechanisms by which platelets lose their function and integrity after in vivo blood-material interaction, remains controversial. In the present study flow cytometry was used for examination of PS exposure at the outer leaflet of the plasma membrane of platelets during $\mathrm{CPB}$, using non-coated and heparin-coated extracorporeal circuits.

In this study, we demonstrate that when the surface of the extracorporeal circuit is coated with heparin, the ionomycin-induced generation of procoagulant platelets is not significantly altered compared to that of non-coated circuits. This indicates that during blood-material contact a small platelet population becomes (partially) activated and is consequently removed from the circulation. Controversial data reported in the literature have suggested that platelet abnormalities observed during $\mathrm{CPB}$ are not due to an "intrinsic defect" of platelets, but, rather results from an "extrinsic defect" such as an in vivo lack of availability of platelet agonists [203]. Our results are in accordance with the findings of Kestin and colleagues [203], but contrast those reported by Ferroni and associates [204]. In fact, despite the high basal levels of platelet procoagulant activity, immediately after start of $\mathrm{CPB}$ a decrease in procoagulant phospholipid activity of platelets was observed after stimulation with ionomycine. This decrease in the potential of ionomycine to induce PS exposure indicates increased platelet sensitivity towards $\mathrm{CPB}$. Moreover, during and after $\mathrm{CPB}$ the platelets remain sensitive in both 
extracorporeal circuits. This may be inferred from the decreased platelet procoagulant activity as a result of platelet activation by ionomycin. It can be argued that this decrease is caused by a significant drop in platelet count during the $\mathrm{CPB}$ procedure. However, the decrease in platelet counts observed with both extracorporeal systems was moderate $(31 \pm 2 \%$ in group A versus $34 \pm 2 \%$ in group $\mathrm{B} ; \mathrm{P}>\mathrm{0.20}$ ). Alternatively, only the platelets that contain surfaces with exposed PS are more rapidly removed from the circulation $[205,206]$.

The lower degree of platelet activation in both systems 15 minutes after protamine administration may be explained by the administration of protamine. In fact, several investigators demonstrated that protamine administration to reverse the heparin anticoagulation effect decreases platelet sensitivity [207-209]. However, approximately $2 \frac{1}{2}$ hours after protamine administration (i.e. 2 hours after closure of the sternum) this decrease of platelet activation reaches a point of significance compared to the platelet activation before interaction with the surface of the extracorporeal circuit. This decrease in the percentage of procoagulant (annexin $\mathrm{V}$ binding) platelets might be caused by a marked decrease in larger, younger, and more adherent platelets after CPB [206,210,211]. In contrast, 24 hours after closure of the sternum, the platelet activation increased significantly in both systems compared to 2 hours after closure of the sternum. This may be due to a recovery of platelet function and volume after $\mathrm{CPB}$, indicating entry of young, larger platelets into the circulation [212]. Furthermore, as discussed above, a certain degree of in vivo platelet activation was present at the baseline. A high percentage of PS exposed platelets, determined in whole blood, were found at sample point 1, i.e. after anesthesia induction and before median sternotomy and before systemic heparinization. It must be considered that in the present study the baseline corresponds with a time point in which patients had already received anesthesia. Indeed, platelet reactivity may be increased after induction of anesthesia for cardiopulmonary bypass operations [213]. Therefore, the possible occurrence of in vivo platelet activation due to anesthetics cannot be ruled out. Solely examining the conditions that alter PS exposure on the outer leaflet of the plasma membrane, does not give a complete picture of the hemostatic effectiveness of these platelets. Therefore, the postoperative chest tube drainage was used as an indicator for platelet related hemostatic effectiveness. The differences among the groups for chest tube drainage during the first 24 hours in the postoperative period coincided with the differences in procoagulant phospholipid activity. Furthermore, there was no statistical difference among the groups for blood and blood product usage.

Recently, Palanzo and colleagues [214] demonstrated that exposure of artificial surfaces to albumin decreases surface affinity for platelets and results in preservation of the circulating platelet count by reducing or eliminating cryopreciptation 
formation during $\mathrm{CPB}$. This would indicate that lack of hemocompatibility of the surface ultimately results in platelet injury.

In conclusion, this clinical study demonstrates that in spite of the use of a heparin-coated circuit during $\mathrm{CPB}$, platelets become modestly activated and are then rapidly removed from the circulation.

\section{Acknowledgements}

The authors would like to thank L.J.B.M.L. Noyez, MD, PhD for his statistical review of our data, as well as, Ms. C. Maassen for her expert laboratory assistance. 
a

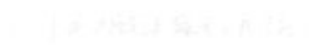

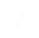

(n)

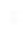

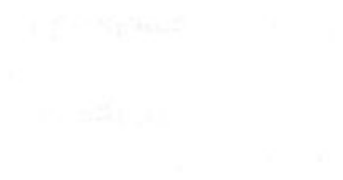




\section{CHAPTER 6}

\section{Thrombin generation during cardiopulmonary bypass: the possible role of retransfusion of blood aspirated from the surgical field}

P.W. Weerwind ${ }^{1}$, T. Lindhout ${ }^{2}$, N.E.H. Caberg ${ }^{3}$, D.S. de Jong ${ }^{3}$.

${ }^{1}$ Department of Extracorporeal Circulation, University Medical Center Nijmegen,

${ }^{2}$ Department of Biochemistry, Maastricht University, ${ }^{3}$ Department of Cardiothoracic Surgery / Extracorporeal Circulation, University Hospital Maastricht, The Netherlands. 


\section{ABSTRACT}

Background. In spite of using heparin-coated extracorporeal circuits, cardiopulmonary bypass (CPB) is still associated with an extensive thrombin generation, which is only partially suppressed by the use of high dosages of heparin. Recent studies have focused on the origins of this thrombotic stimulus and the possible role of retransfused suctioned blood from the thoracic cavities on the activation of the extrinsic coagulation pathway. The present study was designed to find during $\mathrm{CPB}$ an association between retransfusion of suctioned blood from the pericardium and pleural space, containing activated factor VIIa and systemic thrombin generation.

Methods. Blood samples taken from 12 consenting patients who had elective cardiac surgery were assayed for plasma factor VIIa, prothrombin fragment $1+2$ $\left(\mathrm{F}_{1+2}\right)$, and thrombin-antithrombin (TAT) concentrations. Blood aspirated from the pericardium and pleural space was collected separately, assayed for $F_{1+2}$, TAT, and factor VIIa and retransfused to the patient after the aorta occlusion.

Results. After systemic heparinization and during CPB thrombin generation was minimal, as indicated by the lower than base line plasma levels of $F_{1+2}$, and TAT after correction for hemodilution. In contrast, blood aspirated from the thoracic cavities had significantly higher levels of factor VIIa, $\mathrm{F}_{1+2}$, and TAT compared to the simultaneous samples from the blood circulation $(P<0.05)$. Furthermore, after retransfusion of the suctioned blood (range, 200-1600 mL) circulating levels of $\mathrm{F}_{1+2}$, and TAT rose significantly from 1.6 to $2.9 \mathrm{nmol} / \mathrm{L}(P=0.002)$ and from 5.1 to $37.5 \mu \mathrm{g} / \mathrm{L}(P=0.01)$, respectively. The increase in both $\mathrm{F}_{1+2}$, and TAT levels correlated significantly with the amount of retransfused suctioned blood ( $r=0.68, P=0.021$ and $r=0.90, P=0.001$, respectively). However, the circulating factor VIIa levels did not correlate with TAT and $F_{1+2}$ levels.

Conclusions. These data suggest that blood aspirated from the thoracic cavities during $\mathrm{CPB}$ is highly thrombogenic. Retransfusion of this blood may, therefore, promote further systemic thrombin generation during $\mathrm{CPB}$. 


\section{BACKGROUND}

During CPB thrombin generation is extensive [24,215], therefore heparin is administered at high concentrations. The origins of this thrombotic stimulus have been uncertain and subject to speculation. It was reasoned that the contact of the blood with the extracorporeal circuit, via the intrinsic coagulation pathway, was the main contributor to the increased thrombin generation [216]. Elevated levels of activated coagulation factor XIIa during CPB supported this theory [217]. It is, however, doubtful that the contact activation pathway is the main source of the thrombin generation. First, Lane and coworkers $[82,218,219]$ found that tissue factor (TF) is most likely the sole trigger of the coagulation process during CPB. Second, Burman and colleagues [220] found a sharp increase in thrombin generation in a patient with factor XII deficiency during closure of an atrioseptal defect without a significant change in factor IX activation. Thus, factor XII activation is not always indispensable for thrombin generation during CPB.

Recent improvements in biocompatibility of the extracorporeal circuit, such as heparin coatings, have resulted in considerably less blood activation [42,221-224]. Despite these improvements, however, we and also other investigators reported no reduction in thrombin generation in patients undergoing $\mathrm{CPB}$ with the use of a heparin-coated extracorporeal circuit [11,56,225,226], whereas others have found evidence of some possible benefit of these surfaces on the coagulation cascade [146].

Several investigators $[72-74,79]$ have suggested that retransfused suctioned blood from the pericardial cavity could be the major source of a thrombin-generating agent. More recently, Philippou et al [75] demonstrated that pericardiuminduced activation of factor VII, due to ineffective local heparinization, resulted in an increased thrombin generation.

Thus, whereas previous studies suggested that blood is activated predominantly by contact activation, more recent studies indicate that the contribution of the material-independent pathway of blood activation -the surgical wound itselfmay be of much greater importance than previously thought. The aim of this clinical study was to elucidate the impact of retransfused suctioned blood from the thoracic cavities on systemic TF-driven thrombin generation. 


\section{METHODS}

\section{Patients}

Twelve adult patients, subsequently undergoing elective combined heart valve surgery and coronary artery bypass grafting were enrolled in this study. Informed consent was obtained from each patient the day before the operation. The study was approved by the local ethical and research council. No patient had evidence of severe heart failure, renal or hepatic dysfunction, or preoperative coagulopathies. Moreover, no patient was treated with coumarin derivates, platelet-inhibiting drugs, or nonsteroidal anti-inflammatory agents within five days before the operation. The study patients did not receive antifibrinolytic agents during $\mathrm{CPB}$.

\section{Anesthesia and cardiopulmonary bypass}

Anesthesia was induced and maintained with weight-related doses of fentanyl, sufentanil, midazolam, and pancuronium. All patients had Swan-Ganz and arterial catheters placed. The extracorporeal circuit consisted of heparin-coated tubing (Duraflo II, Baxter Bentley Inc., Irvine, CA, USA), a hollow fiber membrane oxygenator (Capiox SX-18, Terumo Corporation, Tokyo, Japan), a heparin-coated venous reservoir (Duraflo II, BMR-1900, Baxter Bentley), an arterial line filter (Pall autovent SV, Pall Biomedical Ltd, Portsmouth, UK), and two biothyl-coated cardiotomy reservoirs (William Harvey H4700, C.R.Bard Inc., Tewsbury, MA, USA). Before connection of the extracorporeal circuit for CPB, each patient received $300 \mathrm{IU} / \mathrm{kg}$ heparin (Heparin Leo, Leo Pharmaceutical Products BV, Weesp, The Netherlands) to achieve an activated coagulation time $($ ACT) $>480$ seconds (Hemotec ACT II, Medtronic Inc., Anaheim, CA, USA). An ACT was measured at baseline, after heparinization, and every 30 minutes during $\mathrm{CPB}$. If necessary, additional boluses of heparin were administered to maintain an ACT > 400 seconds.

After institution of cardiopulmonary bypass at a flow rate of $2.4 \mathrm{~L} / \mathrm{min} / \mathrm{m}^{2}$, and after reaching a blood temperature below $28^{\circ} \mathrm{C}\left(25-28^{\circ} \mathrm{C}\right)$, the heart was topically cooled till fibrillation using cold saline $0.9 \%$ at $4^{\circ} \mathrm{C}$. The aorta was then crossclamped and a single dose of approximately $800 \mathrm{ml}(600-1000 \mathrm{ml})$ of St. Thomas I cardioplegic solution at $4^{\circ} \mathrm{C}$ was infused into the aortic root to provide myocardial preservation. Topic cooling was maintained during the infusion of the cardioplegic solution. Pulsatile perfusion was used throughout the period of aorta crossclamping. During the conduct of $\mathrm{CPB}$, aortic root venting was separated from the cardiotomy suction and in all cases less than $2 \%$ of the calculated 
flow $(<90 \mathrm{ml} / \mathrm{min})$, using a volume pressure control unit with negative pressures less than $50 \mathrm{mmHg}$.

Cardiotomy suction, i.e. blood aspirated from the pericardium and pleural space, was returned to a separated cardiotomy reservoir that was clamped off. After completion of all the distal anastomoses the cardiotomy reservoir clamp was removed, allowing reinfusion of blood from the pericardium and pleural space into the systemic circulation. After CPB, heparin was reversed by $3 \mathrm{mg} / \mathrm{kg}$ protamine chloride (Hoffman/Laroche BV, Mijndrecht, The Netherlands). All pump blood was returned to the patient through the aortic cannula or intravenously via infusion bags without cell washing process or hemoconcentration.

\section{Blood sampling}

During and after the operation, blood samples were collected from each patient at seven specific intervals: before heparin administration (time point 1), $5 \mathrm{~min}$ utes after heparinization before CPB (time point 2 ), 5 minutes after the beginning of $\mathrm{CPB}$ (time point 3), 5 minutes after release of the aortic crossclamp (time point 4), 5 minutes after reinfusion of cardiotomy blood (time point 5), 15 minutes after protamine administration (time point 6), and 2 hours after surgery (time point 7). Additional samples were taken from the pooled blood recollected by suction from the pericardium and pleural space into a cardiotomy reservoir 5 minutes after the beginning of $\mathrm{CPB}$ and 5 minutes after aorta occlusion, before retransfusion.

\section{Laboratory assays}

Blood samples were collected in $3.5 \%$ sodium citrate $(9: 1 \mathrm{vol} / \mathrm{vol})$. Platelet-poor plasma for determination of TAT-complexes, $\mathrm{F}_{1+2}$, and factor VIIa was obtained by centrifugation at $4000 \mathrm{~g}$ for five minutes, and the supernatant was centrifuged at $12000 \mathrm{~g}$ for ten minutes and stored at $-70^{\circ} \mathrm{C}$ until assayed. All samples were corrected for hemodilution.

TAT and $\mathrm{F}_{1+2}$ levels were determined by enzyme-linked immunosorbent assay (Dade-Behring GmbH, Schwalbach, Germany). Factor VIIa levels were determined by a specific immunoassay, which has been described elsewhere [75]. In short, flat-bottomed Maxisorb microtiter plates (Nunc, Roskilde, Denmark) were coated for 2 hours at room temperature or overnight at $4^{\circ} \mathrm{C}$ with $100 \mu \mathrm{L}$ coating buffer containing $5 \mu \mathrm{g} / \mathrm{mL}$ of the rabbit polyclonal antibody RB-23, raised to a region of factor VII exposed following its activation by cleavage at Arg152-Ile153. Thereafter, the wells were blocked during 30 minutes at room temperature with $200 \mu \mathrm{L}$ blocking buffer and then rinsed 5 times with rinse buffer. The wells were incubated for 2 hours at room temperature with $100 \mu \mathrm{L}$ of 
a factor VIIa containing sample and then 6 times rinsed with the rinse solution. Finally, the amount of factor VIIa captured by the rabbit anti-human factor VIIa antibody RB-23 was quantified as follows: $100 \mu \mathrm{L}$ of a solution containing 1:100 diluted thromboplastin (Dade Innovin, Baxter Diagnostics, Deerfield, IL), 10 $\mu \mathrm{mol} / \mathrm{L}$ phospholipid $(20 \mathrm{~mol} \%$ phosphatidylserine and $80 \mathrm{~mol} \%$ phosphatidylcholine), $5 \mathrm{mmol} / \mathrm{L} \mathrm{Ca}^{2+}$ and $250 \mathrm{nmol} / \mathrm{L}$ bovine factor $\mathrm{X}$ [227] in Hepes buffer was added to the well and incubated at $37^{\circ} \mathrm{C}$. The activation of factor X was stopped after 30 minutes by the addition of $35 \mu \mathrm{L}$ Hepes-buffer containing $20 \mathrm{mM}$ EDTA. The amount of formed factor Xa was measured using the chromogenic substrate S2765 as described previously [227]. A calibration curve was constructed with known concentrations of recombinant factor VIIa (Novo Nordisk Pharma, Copenhagen, Denmark).

\section{Statistical analysis}

The results were expressed as the mean \pm standard error of the mean (SEM), except for the patients' demographics, which was expressed as mean \pm standard deviation. Simultaneous samples of the cardiotomy blood and the systemic circulation were compared by the paired Student's $t$ test. This statistic was also used to compare samples during and after $\mathrm{CPB}$ with the sample taken before $\mathrm{CPB}$ and after heparin administration. Spearman's rank correlation analysis was used to measure the relationship between thrombin generation and the amount of retransfused cardiotomy blood and circulating factor VIIa levels, respectively. A p value less than 0.05 was considered to be significant.

\section{RESULTS}

\section{Patients' demographics}

The patients ( 9 men and 3 women) ranged in age from 50 to 76 years, and from 52 to $85 \mathrm{~kg}$ in weight. Table 1 gives descriptive data for the patients, operation, and perfusion. No patients developed bleeding complications; no patients died.

\section{Factor VIIa}

Plasma levels of factor VIIa decreased significantly during bypass from 27.1 to $14.8 \mathrm{\rho mol} / \mathrm{L}$ (Figure 1); the decreases were significant after heparin infusion (between time points 2 and 4). The mean factor VIIa levels from the cardiotomy suction fluid were significantly higher than the levels measured in the systemic circulation at the same sampling points (time points 3 and 4) during CPB (19.7 
Table 1 Patients' demographics (data are presented as mean \pm standard deviation).

Gender, M/F $9 / 3$

Age, years

$68 \pm 8$

Height, $\mathrm{cm}$

$170 \pm 8$

Weight, kg

$75 \pm 12$

Aortic crossclamp time, min (range)

$66 \pm 42(21-141)$

Bypass time, min (range)

$98 \pm 54(41-198)$

Total amount retransfused cardiotomy blood, $\mathrm{mL}$ (range)

$617 \pm 480(200-1600)$

Myocardial revascularization

8

Valve replacement

2

Valve replacement/repair and myocardial revascularization

2

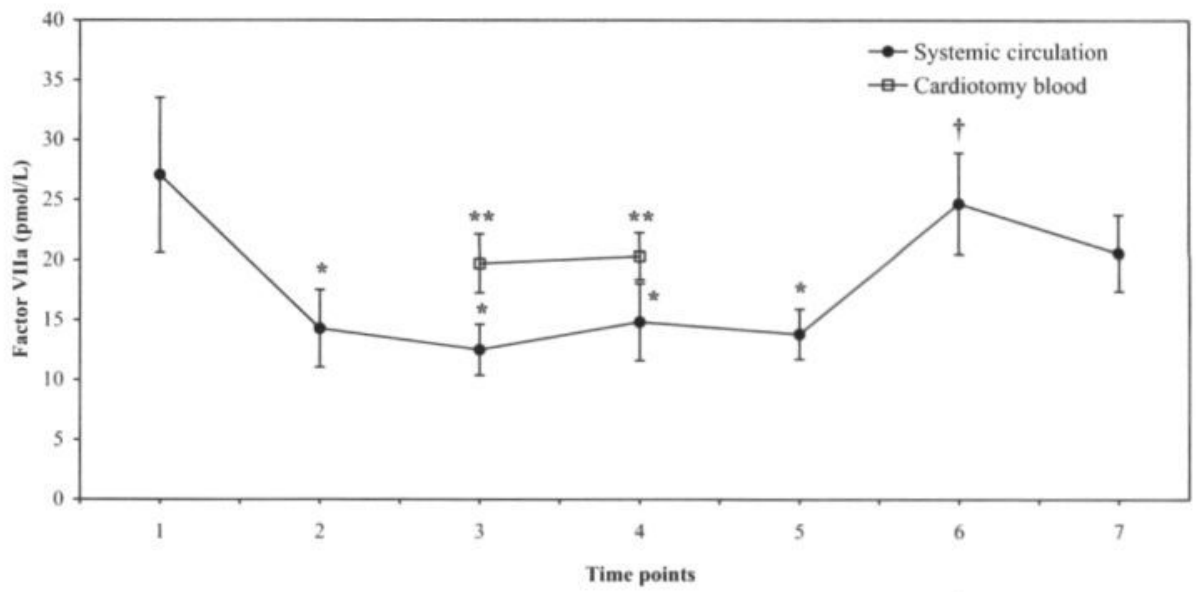

Figure 1 Plasma factor VIIa levels with time in patients undergoing $\mathrm{CPB}(\bullet)$, and in the cardiotomy blood $(\square)$. Blood samples were taken at the various time points as described in the "Patients and Methods" section. Data are presented as mean \pm SEM. Asterisks indicate a statistically significant difference compared with the sample before heparin administration $(P<0.05$ by paired Student's $t$ test); double asterisk indicate a statistically significant difference between the simultaneous samples of the cardiotomy blood and the systemic circulation $(P<0.05$ by paired Student's $t$ test); cross signs indicate a statistically significant difference compared with the sample before retransfusion of the cardiotomy blood ( $P<0.05$ by paired Student's $t$ test). 
and $20.3 \rho \mathrm{mol} / \mathrm{L}$ versus 12.5 and $14.8 \rho \mathrm{mol} / \mathrm{L} ; P=0.01$ for both, respectively). After retransfusion of the cardiotomy blood, surprisingly, no increase in factor VIIa levels was observed in the circulation. Hence, after protamine administration an increase in circulating levels of factor VIIa was noticed.

\section{Prothrombin fragment $1+2$}

The marker of thrombin generation, $\mathrm{F}_{1+2}$, decreased after heparin infusion and after start of CPB (Figure 2). The mean plasma level of $\mathrm{F}_{1+2}$ measured in the cardiotomy blood was significantly higher $(\approx 6$-fold increase) than the levels measured at the same time points in the systemic circulation $(8.2$ and $8.6 \mathrm{nmol} / \mathrm{L}$ versus 1.3 and $1.6 \mathrm{nmol} / \mathrm{L} ; P<0.001$ for both, respectively). After retransfusion of the cardiotomy blood, a dramatic and significant increase was observed in the $\mathrm{F}_{1+2}$ levels from the systemic circulation until 2 hours after the operation (from $1.6 \mathrm{nmol} / \mathrm{L}$ to $3.8 \mathrm{nmol} / \mathrm{L}, P=0.002$ ). In addition, a significant correlation was measured between the amount of retransfused cardiotomy blood and the rise of plasma $\mathrm{F}_{1+2}$ levels in the systemic circulation $(r=0.68, P=0.021)$. No correlation

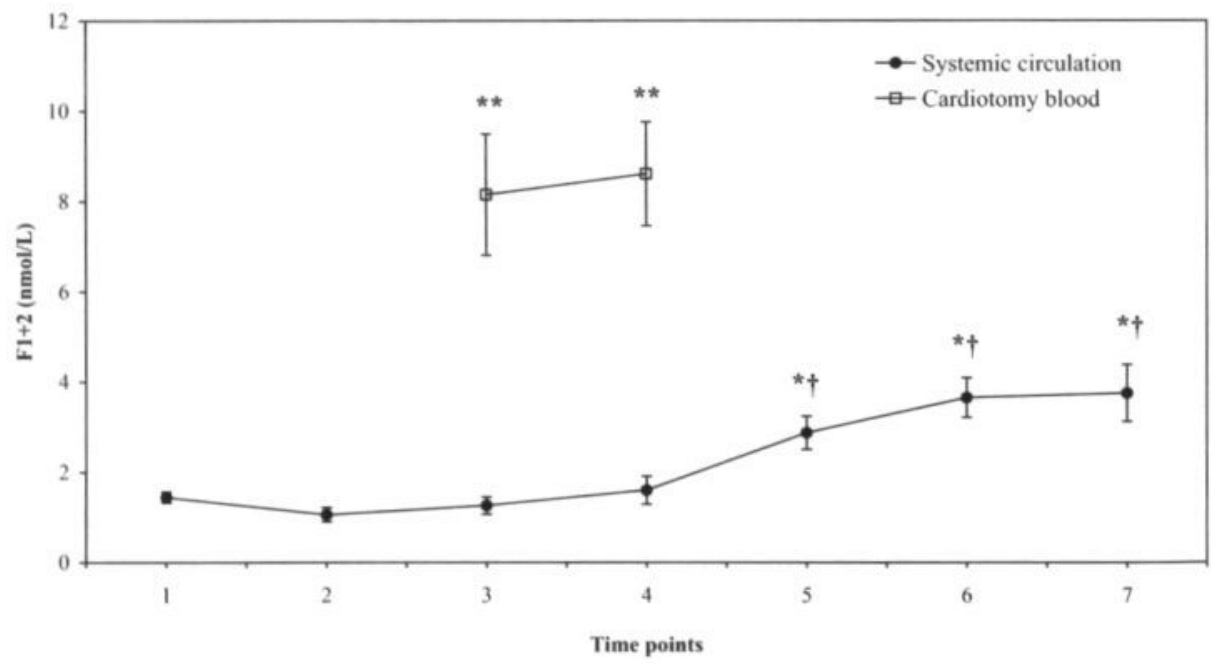

Figure 2 Plasma levels of $\mathrm{F}_{1+2}$ with time in patients undergoing $\mathrm{CPB}(\bullet)$, and in the cardiotomy blood $(\square)$. Blood samples were taken at the various time points as described in the "Patients and Methods" section. Data are presented as mean \pm SEM. Asterisks indicate a statistically significant difference compared with the sample before heparin administration $(P<0.05$ by paired Student's $t$ test); double asterisk indicate a statistically significant difference between the simultaneous samples of the cardiotomy blood and the systemic circulation $(P<0.001$ by paired Student's $t$ test); cross signs indicate a statistically significant difference compared with the sample before retransfusion of the cardiotomy blood $(P<0.05$ by paired Student's $t$ test). 


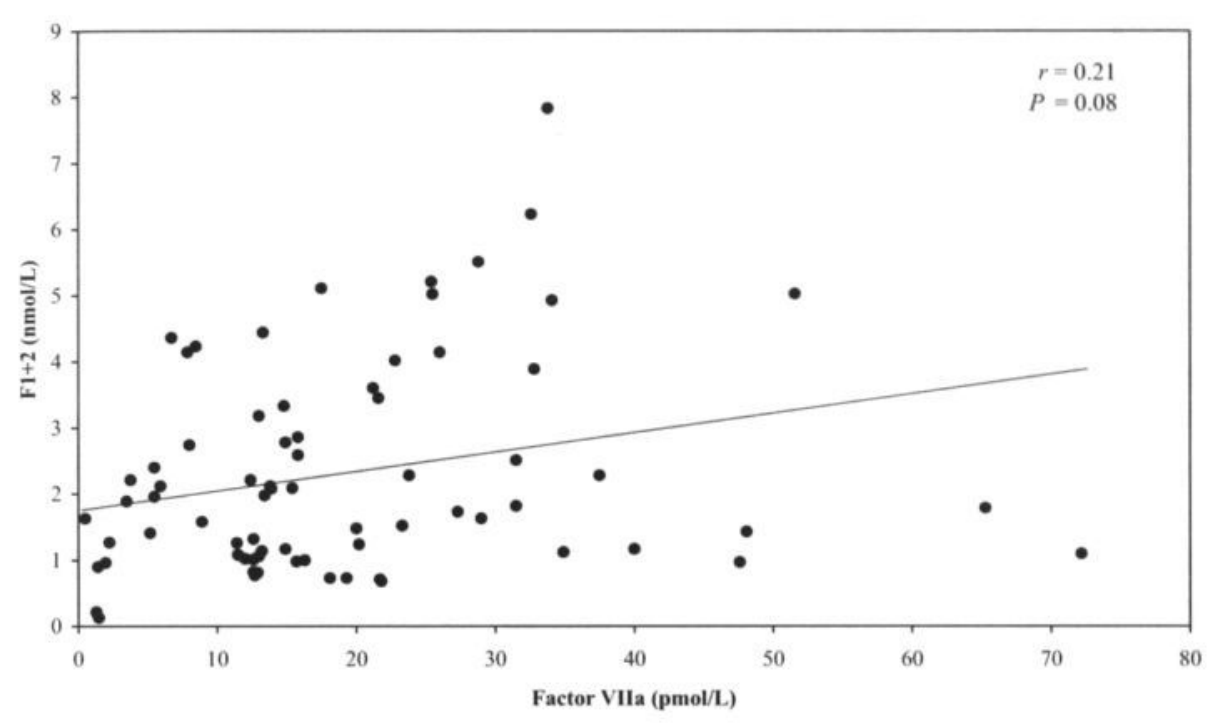

Figure 3 Correlation between circulating factor VIIa levels and $\mathrm{F}_{1+2}$ levels in patients undergoing CPB.

was detected between the circulating $\mathrm{F}_{1+2}$ levels and factor VIIa levels, Figure 3 $(r=0.21, P=0.08)$.

\section{Thrombin-antithrombin}

Plasma concentrations of TAT, a marker of the amount of thrombin that is generated, decreased slightly after heparin infusion and up to the phase of retransfusion of the cardiotomy blood (Figure 4). The mean plasma concentration of TAT measured in the cardiotomy blood was significantly higher ( $>20$-fold increase) than the levels measured at the same time points in the systemic circulation $(105.2$ and $108.8 \mu \mathrm{g} / \mathrm{L}$ versus 3.5 and $5.1 \mu \mathrm{g} / \mathrm{L} ; P<0.001$ for both, respectively). After retransfusion of the cardiotomy blood, plasma TAT concentrations rose significantly in the systemic circulation (from $5.1 \mu \mathrm{g} / \mathrm{L}$ to $37.5 \mu \mathrm{g} / \mathrm{L}, P=0.01)$. Thereafter, the plasma TAT levels remained significantly elevated until 2 hours after the operation $(P<0.05)$. Moreover, close correlation was measured between the amount of retransfused cardiotomy blood and the rise of plasma TAT levels in the systemic circulation $(r=0.90, P=0.001)$. No correlation was detected between the circulating TAT levels and factor VIIa levels, Figure $5(r=0.12, P=0.32)$. 


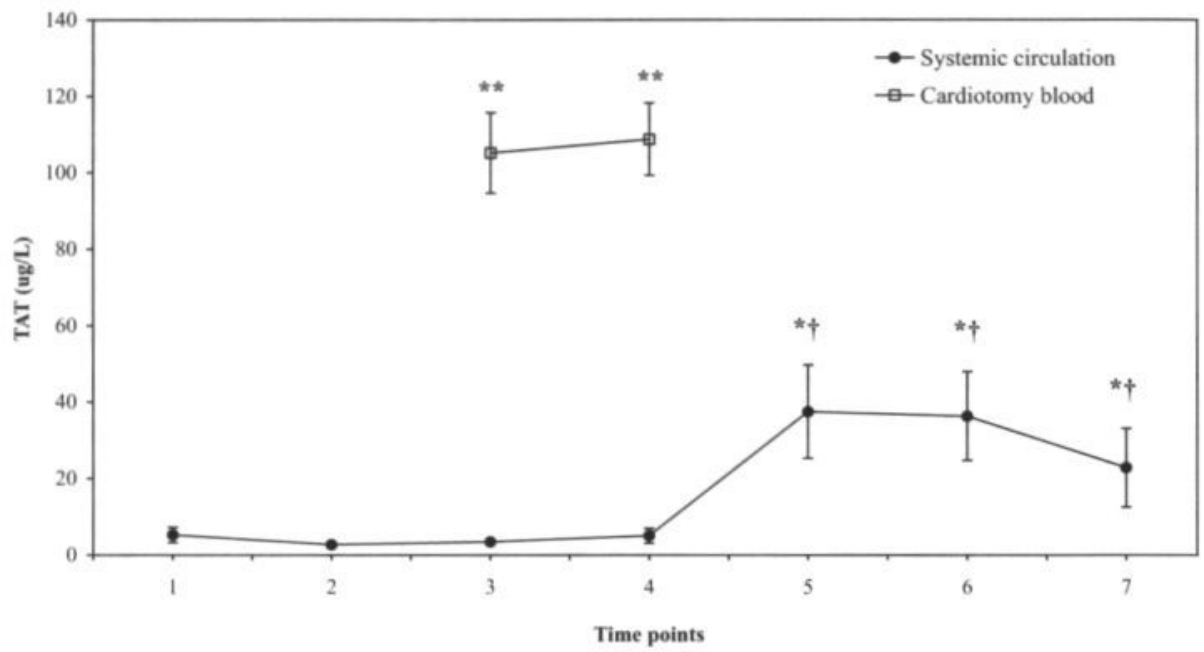

Figure 4 TAT plasma concentrations with time in patients undergoing $\mathrm{CPB}(\bullet)$, and in the cardiotomy blood $(\square)$. Blood samples were taken at the various time points as described in the "Patients and Methods" section. Data are presented as mean \pm SEM. Asterisks indicate a statistically significant difference compared with the sample before heparin administration $(P<0.05$ by paired Student's $t$ test); double asterisk indicate a statistically significant difference between the simultaneous samples of the cardiotomy blood and the systemic circulation $(P<0.001$ by paired Student's $t$ test); cross signs indicate a statistically significant difference compared with the sample before retransfusion of the cardiotomy blood ( $P<0.05$ by paired Student's $t$ test $)$.

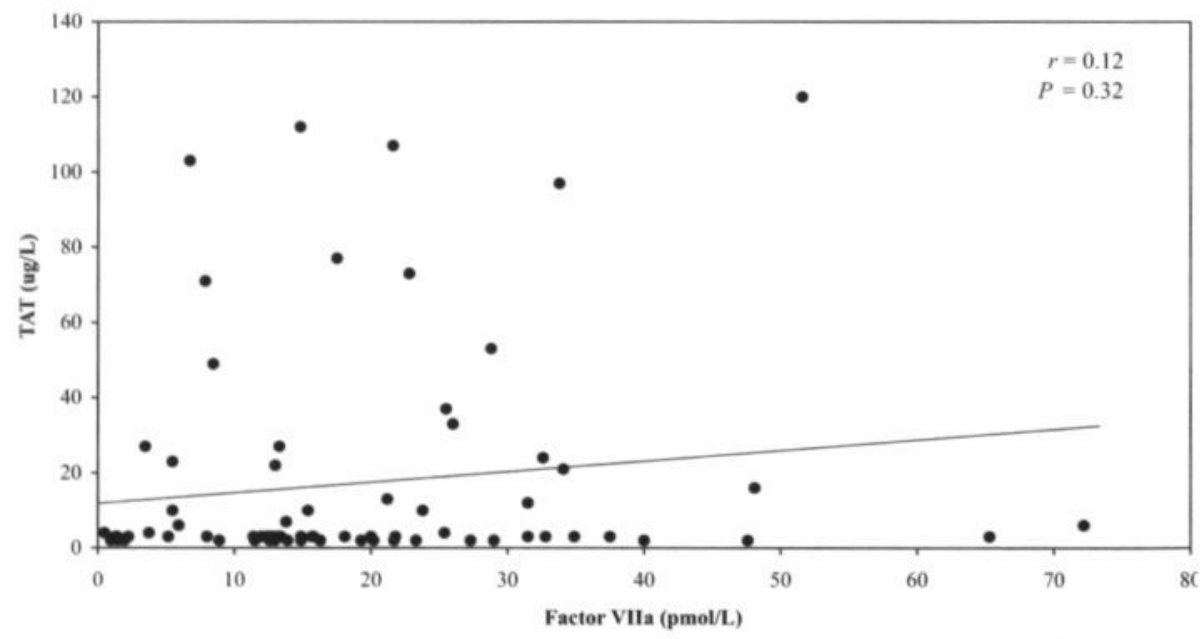

Figure 5 Correlation between circulating factor VIIa levels and TAT levels in patients undergoing CPB. 


\section{DISCUSSION}

To diminish allogeneic blood transfusions and volume loss in the extracorporeal circulation, retransfusion of suctioned blood from the thoracic cavities during $\mathrm{CPB}$ is considered a salutary technique. However, recent reports have highlighted the quality of this blood and its relative role on the activation of tissue factor pathway [75-77]. In the present study we found evidence that blood aspirated from the pericardium and pleural space is highly thrombogenic, because of an excellent correlation between the amount of retransfused blood and the increased levels of TAT and $\mathrm{F}_{1+2}$. The origin of ongoing thrombin generation is most likely caused by the presence of TF rather than factor VIIa in the blood aspirated from the pericardium and pleural space [228].

Triggering of the in vivo coagulation is thought to require complex formation between TF and factor VIIa to form an activation complex that converts factor $\mathrm{IX}$ and $\mathrm{X}$ into the serine proteases factor IXa and $\mathrm{Xa}$, respectively. Factor $\mathrm{Xa}$ is the enzyme that ultimately generates thrombin [229]. Chung and associates [73] showed that blood mononuclear cells taken from the pericardium express twice the level of TF compared with cells taken simultaneously from the systemic circulation. In addition, in vivo thrombin generation is at least partly mediated by cell-derived microparticles containing TF [81]. In this study we found that blood aspirated from the thoracic cavities had significantly higher levels of factor VIIa compared to the simultaneous samples from the systemic circulation. Because TF is an essential cofactor for factor VIIa generation [229], high factor VIIa levels in blood aspirated from the pericardium and pleura space reflects the presence of significant amounts of TF.

Accordingly to the presence of TF in the blood aspirated from the thoracic cavities, corresponding elevations in markers of direct thrombin generation were observed. In addition, this study is the first to provide direct evidence that the amount of retransfused cardiotomy blood volume contributes to the level of thrombin generation during CPB. Close correlation was established between the amount of retransfused cardiotomy blood and the rise of plasma TAT levels and $\mathrm{F}_{1+2}$ levels in the systemic circulation. Retransfusion of an amount as minimal as $200 \mathrm{~mL}$ cardiotomy blood already resulted in a systemic increase of $8 \%$ in plasma TAT concentrations and $0.4 \%$ in plasma $\mathrm{F}_{1+2}$ concentrations. These results confirm the suggestions and findings of others that the general practice of retransfusion of cardiotomy blood is a potential source of activated hemostatic components [72-77]. A possible explanation for the high activation marker levels in the blood aspirated from the thoracic cavities might be poor local anticoagulation. It has been reported that pericardial blood had lower levels of heparin than corresponding perfusate samples, and the levels of heparin in samples from the thoracic cavities correlated inversely with those of thrombin genera- 
tion markers and factor VIIa [75]. Alternatively, it is tempting to speculate that the concentration of the natural inhibitor of the TF/factor VIIa complex, tissue factor pathway inhibitor (TFPI), in the suctioned blood is greatly reduced, which in turn greatly amplifies thrombin generation. Additional anticoagulation of the cardiotomy blood seems thus required. The notion that anticoagulation must be focused on inhibiting TF-driven blood coagulation is also supported by the observation that local administration of aprotinin, an inhibitor of the intrinsic blood coagulation, in the thoracic cavities did not prevent generation of highly procoagulant mediators in blood aspirated from these cavities [230].

In conclusion, we demonstrated that blood aspirated from the pericardium and pleural space is highly thrombogenic, and retransfusion of this blood may promote systemic thrombin generation during $\mathrm{CPB}$. Therefore, as been pointed out by others $[72,74,76,77,79]$, this blood should be discarded or processed with a cell salvage system prior to retransfusion. 


\section{CHAPTER 7}

\section{General Discussion}

Extracorporeal circulation of blood induces activation of cellular blood components and consequently impairment of the homeostatic function of blood. These effects are most pronounced during use of CPB for cardiac surgery, due to the large surface area of the circuit to which blood is exposed and the high blood flow through the extracorporeal circuit [4,5,7-10,12,231-233]. This extensive blood activation process in combination with a standardized and routinely performed surgical technique renders $\mathrm{CPB}$ an attractive model for studying blood-material interaction and its clinical consequences. The procedure of $\mathrm{CPB}$ consists of temporary mechanical blood pumping and blood gas exchange, in order to exclude heart and lungs from circulation. The extracorporeal circuit consists of different vital artificial components: a hollow fiber membrane oxygenator, a venous reservoir, an arterial line filter, and a cardiotomy reservoir. Altogether, the extracorporeal circuit consists of a variety of materials like: polypropylene, polycarbonate, polyvinylchloride, polyester, silicone rubber, polyethylene, polyurethane, polysulfone, teflon, and stainless steel, which come in contact with blood. This makes it difficult to correlate the observed blood activation with the use of a specific material. In addition to the material-induced blood activation, the surgical procedure also includes considerable tissue trauma and exposure of recirculating blood from the traumatised area. It has been attempted to counteract these adverse effects of $\mathrm{CPB}$ by employing biocompatible materials [5,233-235], by pharmacological treatment of the patients [236-240], and by surface coating of the blood-contacting area [12,35,43,49,56,58,146,241-244]. However, the pathophysiology of CPB appeared to be complex and multifactorial. Therefore, investigation of the underlying mechanisms needed a multiparameter approach.

In this thesis a series of studies were performed to obtain more insight in the hemocompatibility of the extracorporeal circuit, with the intention of characterizing the performance benefits of heparin-treated circuits.

First, the inhibiting effects of heparin-treated extracorporeal circuits on the activation of the kinin and coagulation system during $\mathrm{CPB}$ were investigated in adult patients undergoing elective myocardial revascularization (Chapter 2). Low amounts of kallikrein- $\mathrm{C}_{1}$-inhibitor complexes $(<1 \mathrm{U} / \mathrm{ml})$ indicated a marginal 
effect on contact activation of blood. Other authors [245,246] have reported similar findings. Despite these observations, activation of the contact system could not always been excluded [241]. The contradictory results may in part be explained by the rapid in vivo clearance of enzyme-inhibitor complexes, since formation of kallikrein- $\mathrm{C}_{1}$-inhibitor complexes were observed immediately after the start of simulated extracorporeal circulation [216,247,248]. Furthermore, heparin coating did not appear to reduce activation of clotting and platelets by thrombin acceleration inactivation. This was elucidated by elevated $F_{1+2}$ and TAT plasma levels during CPB in both untreated and heparin-treated extracorporeal circuits, despite the heparin causing significantly systemic anticoagulation, i.e. the ACT was prolonged to greater than 480 seconds throughout the entire surgical procedure. A discussion is ongoing whether heparin dosing during $\mathrm{CPB}$ on the basis of $\mathrm{ACT}$ measurement is optimal or whether heparin by itself is an adequate anticoagulant in this setting.

Considering that the intrinsic pathway did not initiate the coagulation process, our findings imply that thrombin generation occurs independently from contact activation. This is supported by several other studies $[51,56,226]$. Thrombin generation during $\mathrm{CPB}$ might mainly be driven by $\mathrm{TF}$ and may be independent of the use of heparin-treated extracorporeal circuits. In agreement herewith, patients with a severe factor XII deficiency undergoing cardiac surgery showed comparable thrombin formation to normal individuals [220]. Conversely, activation of the contact system seems to be related to fibrinolysis. Patients with a severe factor XII deficiency (factor XII < 1\%) demonstrated impaired fibrinolytic activity after desamino D-arginine vasopressin stimulation [249]. In our study, however, we found no direct support for involvement of the contact system in fibrinolysis. Although low amounts of kallikrein- $\mathrm{C}_{1}$-inhibitor complexes were observed, PAP levels were increased in both heparin-treated and untreated circuits instead of reduced. Fibrinolytic activity was augmented up to 2 hours after $\mathrm{CPB}$ in both groups, which was in accordance with elevated $\mathrm{F}_{1+2}$ plasma levels. In addition, the PPP was elevated during the course of CPB in a similar pattern in both the heparin-treated and untreated circuit, indicating a higher excitability of the procoagulant phospholipids activity of platelets compared to baseline values. Accordingly, no differences in mediastinal blood loss and clinical outcome were observed between the two groups. Evidently, to what extent the impairment of hemostasis was not prevented, was not entirely clear after this clinical evaluation. It was concluded that based on these results, an advantage of using heparin-treated extracorporeal circuits to preserve hemostatic qualities during routine $\mathrm{CPB}$ procedures could not be confirmed.

In contrast to this lack of thromboresistant characteristics of heparin-treated extracorporeal circuits, several investigators reported that heparin coating of an artificial surface reduced complement activation and might thus bear the poten- 
tial to change leukocyte activation and subsequently the leukocyte-endothelium interaction $[46,47]$. Therefore, we evaluated whether the use of heparin-treated extracorporeal circuits could reduce the leukocyte-mediated inflammatory response during CPB (Chapter 3). This study demonstrated that heparin coating of the extracorporeal circuit significantly reduced the systemic inflammatory reaction caused by $\mathrm{CPB}$ as measured by plasma levels of inflammatory mediators, and thus may alter the leukocyte-endothelium interaction. In agreement with other studies $[152,153]$ increased plasma IL-8 levels in patients undergoing cardiac surgery with the use of $\mathrm{CPB}$ without heparin-treated extracorporeal circuits were observed. IL- 8 which is produced by monocytes, macrophages, fibroblasts and vascular endothelial cells following stimulation with TNF- $\alpha$, IL-1 or lipopolysaccharide [154], is considered to be an important and early mediator of neutrophil-mediated inflammatory reactions as it strongly attracts neutrophils and enhances their activation. The use of a heparin-treated system showed a remarkable reduction in circulating IL-8 levels. An increase of IL-8 did not occur until 3 to 6 hours after the end of bypass. Moreover, the kinetics of other proinflammatory cytokines (soluble TNF- $\alpha$ receptors, sIL-6) that were measured, suggests that heparin coating prevented the onset of an early inflammatory response during $\mathrm{CPB}$.

Furthermore, the soluble adhesion molecule E-selectin increased above baseline starting 3 to 6 hours after aortic crossclamp release in both the heparin-treated as the untreated group, whereas only a modest increase in sICAM-1 was observed 24 hours after CPB. E-selectin is only found on activated endothelium on which it interacts with carbohydrate ligands and mediates the initial rolling of leukocytes on the endothelium. Endothelial cells have been shown to release E-selectin following in vitro stimulation [147]. Therefore, specific elevations in levels of $s \mathrm{E}$-selectin would indicate activation or damage of the endothelium. The presence of higher levels of sE-selectin at 12 hours after $\mathrm{CPB}$ suggests that a more pronounced endothelial inflammatory reaction occurred with the non heparin-treated circuits. ICAM-1 is constitutively expressed on vascular endothelial cells and a number of other cell types including fibroblasts, epithelial cells and peripheral blood mononuclear cells and is particularly involved in the firm attachment and transendothelial migration of leukocytes [161]. Its expression is upregulated following activation during an inflammatory response. The initial drop in circulating sICAM-1 in patients who underwent CPB with the uncoated circuits suggests an increase in activated leukocytes as ligand binding by activated leukocytes may clear sICAM-1 from the plasma.

Since heparin coating of the extracorporeal circuit almost completely prevented early proinflammatory cytokine production, one may conclude that the heparin-treated surface exerts its protective effect by modifying mediators of the inflammatory cascade rather than from a direct interaction of heparin coating 
and coagulation or fibrinolysis. Whether these findings are associated with an attenuated acute-phase response remains to be established. On the other hand, there is a high degree of intraindividual variability in the extent of inflammatory reaction to $\mathrm{CPB}$ and the consequent clinical complications. Many factors (e.g. smoking, psychological stress, infection, unstable angina, chronic inflammatory disease) may activate a systemic inflammatory reaction that may worsen the response to $\mathrm{CPB}$ [63]. Moreover, an individual genetic predisposition to produce a greater inflammatory response to similar stimuli may also be important. Finally, preoperative inflammatory markers, such as C-reactive protein, may prove to be markers of prognosis in cardiac surgery as they have already been shown to be in patient groups with ischemic heart disease.

Our knowledge of the protective effect of heparin-treated extracorporeal circuits on the systemic inflammatory cascade activation, and the activation patterns from direct and indirect thrombin generation, and fibrinolysis as discussed in chapters 2 and 3, led us to study the intrinsic thrombogenicity of the extracorporeal circuit in more detail. We noted that to achieve clinical benefit from heparin-treated extracorporeal bypass circuits, several changes might be required in the way clinical $\mathrm{CPB}$ is performed. For this, we conducted a study in an animal model with the intend to elucidate the intrinsic thrombogenicity of the extracorporeal circuits and the benefit of heparin-treated circuits in an extracorporeal life support system without full systemic heparinization and with minimal interference of the so-called biomaterial-independent stimuli (Chapter 4). Not returning pericardial blood to the systemic circulation and reducing systemic heparinization, limiting heart and lung reperfusion injury, and using specific priming solutions may all be needed to elucidate the beneficial effects of heparin-coated circuits. It is likely that these factors allowed biomaterialindependent stimulation of the body's defense system to overwhelm any material-dependent mitigating properties of heparin-treated circuits. The results from this ex vivo study showed that a heparin-treated extracorporeal life support system could be run without any additional systemic heparinization once the initial bolus injection is cleared from the circulation. However, one of the most important requirements for effective application of heparin-treated circuits is that a certain level of blood flow is maintained [31-33]. Stagnant areas and drastic lowering of flow rates or even total stoppage of blood flow in the cannulae, for instance were avoided. These are strict limitations in design of the extracorporeal life support systems and should be further investigated. One should also remember that even in an intact blood vessel, stagnation of blood stimulates coagulation.

As a result of profound activation of the coagulation cascade indicated by increased plasma FPA levels in the non heparin-treated experiments, the blood vessels seen in a biopsy specimen obtained from lung tissue immediately following sacrifice of the animal were partially or completely occluded with fibrin. No 
fibrin deposition was seen in the lung preparations of the animals perfused with a heparin-treated extracorporeal circuit.

The results from this ex vivo study clearly showed that surface heparin bonding has a thromboresistant effect, and therefore it can reduce the need for systemic heparinization in a heparin-treated extracorporeal life support system. Moreover, measurement of FPA levels showed to be a valuable test of the clotting activity in an extracorporeal system.

Platelet dysfunction seems to play a central role in CPB. Thrombocytopenia as a result of platelet activation is known to occur during and after $\mathrm{CPB}$. Exposure of blood to artificial surfaces causes platelet adhesion and $\alpha$-granule release, with liberation of platelet factor $4, \beta$-thromboglobulin, and platelet-derived growth factor, and expression of P-selectin on the surface of the activated platelet [250]. Moreover, potent activation by agonists such as thrombin results in the release of dense granule contents, which liberates additional platelet agonists and generates platelet-platelet aggregates that promote thrombus formation. Although platelet damage, in part, can be prevented pharmacologically, it would be most beneficial to prevent generation of thrombin to abrogate the adhesion and activation of platelets on artificial surfaces. For that reason a clinical study was designed to elucidate whether the potential procoagulant activity of platelets, detected as annexin $\mathrm{V}$ binding, was altered during coronary bypass surgery, using untreated and heparin-treated extracorporeal circuits (Chapter 5). In this study it was demonstrated that when the surface of the extracorporeal circuit is coated with heparin, the percentage of platelets that bind annexin $\mathrm{V}$ is not significantly altered relative to that of uncoated circuits suggesting that when during blood-material contact platelets become activated they are rapidly removed from the circulation. Indeed, platelets from both groups showed a significantly lower ability to generate ionomycin-induced procoagulant activity after blood-material interaction when compared to the baseline values.

Solely examining the conditions, which alter PS exposure on the outer leaflet of the platelet plasma membrane, does not give a complete picture of the hemostatic effectiveness of these platelets. Therefore, the postoperative chest tube drainage was used as an indicator for platelet related hemostatic effectiveness. The differences among the groups for chest tube drainage during the first 24 hours in the postoperative period coincided with the differences in procoagulant phospholipid activity. Furthermore, there was no statistical difference among the heparin-coated and uncoated group for blood and blood product usage. Our observations from this study were compatible with the notion that during CPB, irrespective of the heparin coating, platelets become modestly activated and are then rapidly removed from the circulation.

Several studies have indicated that the contribution of the material-independent pathway of blood activation -the surgical wound itself- may be of much greater 
importance than previously thought. Ineffective local heparinization and retransfusion of highly procoagulant cell-derived microparticles were implicated as the main source of this material-independent activation in patients during CPB $[72-75,79]$. Subsequently, to elucidate the impact of retransfused suctioned blood from the thoracic cavities on systemic TF-driven thrombin generation, a clinical study was conducted with separation of the shed blood (Chapter 6).

Triggering of the in vivo coagulation is thought to require complex formation between TF and factor VIIa to form an activation complex that converts factor $\mathrm{IX}$ and $\mathrm{X}$ into the serine proteases factor IXa and $\mathrm{Xa}$, respectively. Factor $\mathrm{Xa}$ is the enzyme that ultimately generates thrombin [229]. It has been shown that blood mononuclear cells taken from the pericardium express twice the level of TF compared with cells taken simultaneously from the systemic circulation [73]. In addition, in vivo thrombin generation involves a factor VII/TF-dependent pathway, which is at least partly mediated by cell-derived microparticles [81]. Consequently, evidence of increased amounts of TF is associated with increased factor VIIa levels [229]. The blood aspirated from the thoracic cavities in our study had significantly higher levels of factor VIIa relative to the corresponding samples taken from the circulation, suggesting the involvement of TF-driven factor VIIa generation in the pericardium and pleura cavity. Accordingly to elevated plasma factor VIIa levels measured in the blood aspirated from the thoracic cavities, corresponding elevations in markers of direct thrombin generation were observed. Moreover, this study is the first to provide direct evidence that the amount of retransfused cardiotomy blood volume contributes to the level of thrombin generation during CPB. Close correlation was established between the amount of retransfused cardiotomy blood and the rise of plasma TAT levels and $\mathrm{F}_{1+2}$ levels in the systemic circulation. Retransfusion of an amount as minimal as $200 \mathrm{~mL}$ cardiotomy blood already resulted in a systemic increase of $8 \%$ in plasma TAT concentrations and $0.4 \%$ in plasma $\mathrm{F}_{1+2}$ concentrations.

Limited systemic thrombin generation during $\mathrm{CPB}$ was observed in this study, so it was not necessary to invoke circuit-dependent mechanisms of coagulation activation in addition to the pericardium and pleural source. However, this finding of minimal circuit thrombin generation does not exclude additional mechanisms of triggered activation in the systemic circulation, such as those arising from leukocytes and platelets $[76,77]$. A possible contributory explanation for more extensive activation of coagulation in the extracorporeal circuit in other studies might be discrepancies in anticoagulation therapies. The result from this study demonstrated that blood aspirated from the pericardium and pleural space is highly thrombogenic. Therefore, retransfusion of this blood may promote further systemic thrombin generation during $\mathrm{CPB}$, which explains in part the increased bleeding tendency in the first postoperative period after CPB. 
On reviewing our results related to blood activation during the use of CPB for cardiac surgical treatment, it is concluded that the complete surgical procedure has to be taken into account, since blood activation appears to have multiple causes. The composition of the extracorporeal circuit and the polymers used for the circuit are not the only cause of a thrombotic insult and platelet derangement. Instead, directly retransfusing blood aspirated from the thoracic cavities into the systemic circulation strongly promotes thrombin generation during $\mathrm{CPB}$. Consequently, inducing an impairment of the platelets by proteolytic attacks of platelet membrane receptors. Further improvement of hemostasis during CPB, without use of pharmacological agents, can be achieved when deleterious plasma components are removed from blood prior to retransfusion. Meanwhile, extracorporeal circulation with a closed system and limited surgery seems to offer improved hemocompatibility with heparin treatment of the blood-contacting surface. In these situations, the activation of the clotting system is greatly reduced. Consequently, systemic heparinization can be considerably reduced or even omitted. Moreover, heparin-treated extracorporeal circuits have shown to prevent the early activation of inflammatory cascades and, thus, appear promising. Therefore, in spite of the mostly very transient CPB-related disorders observed during and after routine cardiac surgery, which hardly can be correlated to morbidity or to hospitalization, heparin-treated circuits may be of benefit in high-risk patients (e.g. elderly or very young patients, and patients with preexisting organ failure), in cases where prolonged $\mathrm{CPB}$ times are anticipated, or for extended cardiopulmonary or respiratory support. While the homeostatic condition of patients can be very accurately monitored today, further research is needed to improve the postoperative recovery of patients undergoing CPB. Thus, the totally hemocompatible extracorporeal circuit will remain a challenge for biomedical scientists. 


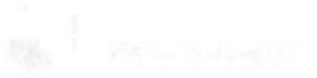

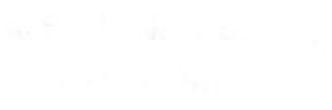

- 


\section{CHAPTER 8}

\section{Summary}

$\mathrm{CPB}$ is a method of whole body perfusion in which the function of the heart and lungs is replaced with an extracorporeal circuit consisting of different vital artificial components: an artificial lung, several reservoirs and filters, and tubing. The use of an extracorporeal circuit provides a controlled environment for surgery of the heart and great vessels. Although nowadays CPB can be considered a safe procedure, the systemic inflammatory response and bleeding complications can still be considered as drawbacks of the use of CPB. The deleterious effects have been attributed to both material-dependent and -indepent aspects of CPB. Thus, the pathophysiology of CPB appeared to be complex and multifactorial. Therefore, investigation of the underlying mechanisms needed a multiparameter approach. In this thesis a series of studies were performed to obtain more insight in the hemocompatibility of the extracorporeal circuit, with the intention of characterizing the performance benefits of heparin-treated circuits.

The inhibiting effects of heparin-treated extracorporeal circuits on the activation of the kinin and coagulation system during $\mathrm{CPB}$ were investigated in adult patients undergoing elective myocardial revascularization (Chapter 2). The initiation of the blood coagulation process as well as the kinin system was hardly activated by the interaction of blood with the extracorporeal circuit. Furthermore, the use of a heparin-treated circuit did not impair thrombin generation, fibrinolysis, and procoagulant phospholipids activity of platelets during $\mathrm{CPB}$. Accordingly, the postoperative blood loss, intensive care unit stay, and the duration of hospital stay were not altered using a heparin-treated system. Based on these results, an advantage of using heparin-treated extracorporeal circuits during routine $\mathrm{CPB}$ procedures could not be confirmed.

In contrast to this lack of thromboresistant characteristics of heparin-treated extracorporeal circuits, several investigators reported that heparin coating of the material surface reduced complement activation and might thus bear the potential to change leukocyte activation and subsequently the leukocyte-endothelium interaction. Therefore, we evaluated whether the use of heparin-treated extracorporeal circuits could reduce the leukocyte-mediated inflammatory response during $\mathrm{CPB}$ (Chapter 3 ). This study demonstrated that heparin coating of the extracorporeal circuit significantly reduced the systemic inflammatory reaction caused by $\mathrm{CPB}$ and could alter the leukocyte-endothelium interaction. 
It is conceivable that the heparin-treated surface exerts its protective effect by modifying mediators of the inflammatory cascade rather than from a direct interaction of heparin coating and coagulation or fibrinolysis.

Our knowledge of the protective effect of heparin-treated extracorporeal circuits on the systemic inflammatory cascade activation, and the activation patterns from the thrombin generation/inhibition, and fibrinolysis data as discussed in chapters 2 and 3, led us to study the intrinsic thrombogenicity of the extracorporeal circuit in more detail. We noted that to achieve clinical benefit from heparin-treated extracorporeal bypass circuits, several changes might be required in the way CPB is performed. For this, we conducted a study in an animal model with the intend to elucidate the intrinsic thrombogenicity of the extracorporeal circuits and the benefit of heparin-treated circuits in an extracorporeal life support system without full systemic heparinization and with minimal interference of the so-called biomaterial-independent stimuli (Chapter 4). The results from this ex vivo study clearly showed that surface heparin bonding has a thromboresistant effect, and therefore can reduce the need for systemic heparinization in a heparin-treated extracorporeal life support system. Moreover, measurement of fibrinopeptide A levels showed to be a valuable test of the clotting activity in an extracorporeal system.

Since CPB is still associated with an induced hemostatic defect, in which platelet dysfunction seems to play a central role, a clinical study was designed to elucidate whether the potential procoagulant activity of platelets, detected as annexin $\mathrm{V}$ binding, was altered during coronary bypass surgery using untreated and heparin-treated extracorporeal circuits (Chapter 5). The observations from this study were compatible with the notion that during $\mathrm{CPB}$, irrespective of the heparin coating, platelets become modestly activated and are then rapidly removed from the circulation.

In addition, to the material-associated blood activation, also material-independent blood activation occurs during CPB. Recent studies have indicated that the contribution of the material-independent pathway of blood activation -the surgical wound itself- may be of much greater importance than previously thought. Ineffective local heparinization and retransfusion of highly procoagulant cell-derived microparticles were implicated as the main source of this material-independent activation in patients during $\mathrm{CPB}$. In order to elucidate the impact of retransfused suctioned blood from the thoracic cavities on systemic TF-driven thrombin generation, a clinical study was conducted with separation of the shed blood (Chapter 6). The data from this study showed that blood aspirated from the thoracic cavities during $\mathrm{CPB}$ is highly thrombogenic. Retransfusion of this blood may, therefore, promote further systemic thrombin generation during $\mathrm{CPB}$, which explains in part the increased bleeding tendency in the first postoperative period after cardiac surgery with the use of CPB. 
On reviewing our results related to blood activation during $\mathrm{CPB}$, it is concluded that the complete surgical procedure has to be taken into account. Blood activation appears to have multiple causes, which is manifest by a systemic inflammatory response and bleeding complications. In routine cardiac surgical procedures, these disorders are mostly very transient and can hardly be correlated to morbidity or to the duration of the hospitalization. However, nowadays we are facing a shift in patient's population from more routine elective surgery to surgery on elderly (over 80 years) or very young patients, on patients with preexisting organ failure, re-operations and emergencies. Therefore, our knowledge of the responses of blood to different biomaterials has to be extended to make sure that hemocompatible materials are applied. The greatest benefit that is to be expected from surfaces in addition to being hemocompatible is active elimination of activation products from other origins, such as the wound area. Thus, further research is needed to improve the postoperative recovery of patients undergoing cardiac surgery with the use of CPB. 



\section{CHAPTER 9}

\section{Samenvatting}

Cardiopulmonale bypass (CPB) is een kunstmatige methode voor de vervanging van de totale bloedcirculatie en perfusie van organen, waarbij de hart- en longfunctie tijdelijk vervangen worden door een circulatiesysteem buiten het lichaam om, ook wel extracorporale circulatie genoemd. Een dergelijk circulatiesysteem bestaat uit verschillende vitale componenten: een kunstlong, enkele reservoirs en filters, en een kunststof slangencircuit. Het gebruik van extracorporale circulatie zorgt voor een gecontroleerde omgeving voor het uitvoeren van chirurgie van het hart en/of de grote bloedvaten. Hoewel het gebruik van CPB tegenwoordig als een veilige procedure beschouwd kan worden, kunnen systemische ontstekingsreacties en bloedingscomplicaties nog steeds als belangrijke nadelen worden gezien. Deze nadelige effecten worden zowel toegeschreven aan interacties van het bloed met het materiaal van het extracorporaal systeem, als aan algemene materiaal onafhankelijke aspecten. De pathofysiologie van CPB lijkt dus complex en van vele factoren afhankelijk te zijn. Derhalve was voor het onderzoek naar onderliggende mechanismen een multiparameter benadering nodig. Dit proefschrift beschrijft een reeks onderzoeken die zijn uitgevoerd om meer inzicht in de hemocompatibiliteit van het extracorporale systeem te verkrijgen, met als doel het karakteriseren van de voordelen van het gebruik van heparine gecoate extracorporale circuits.

De remmende effecten van heparine voorbehandelde extracorporale circuits op de activering van het kininesysteem en van het stollingssysteem tijdens CPB zijn onderzocht bij volwassen patiënten, welke een electieve coronaire bypass operatie ondergingen (hoofdstuk 2). Zowel de initiatie van het bloedstollingsproces als de initiatie van het kininesysteem werden nauwelijks beïnvloed door de interactie van bloed met het extracorporale circuit. Bovendien werd de trombine generatie, de fibrinolyse en de procoagulante fosfolipiden activiteit van de bloedplaatjes tijdens CPB niet verminderd bij het gebruik van een heparine gecoat extracorporaal circuit. In overeenstemming hiermee was er bij het gebruik van een heparine gecoat circuit ook geen verandering in het postoperatieve bloedverlies, het verblijf op de afdeling 'intensive-care' en de duur van de gehele ziekenhuisopname. Gebaseerd op deze resultaten kon een voordeel van het gebruik van heparine 
gecoate extracorporale circuits tijdens routine $\mathrm{CPB}$ procedures niet worden bevestigd.

In tegenstelling tot dit gebrek aan tromboresistente eigenschappen van de heparine gecoate extracorporale circuits, hebben verschillende onderzoekers gerapporteerd dat deze oppervlakte modificatie van het extracorporale circuit met behulp van heparine complement activatie verminderde. Dit zou dus de mogelijkheid kunnen bieden om de activering van witte bloedlichaampjes te verminderen en daardoor tevens de interactie tussen witte bloedlichaampjes en het endotheel te beïnvloeden. We hebben daarom geëvalueerd of het gebruik van een heparine voorbehandeld extracorporaal circuit de door witte bloedlichaampjes geïnduceerde ontstekingsreacties tijdens het gebruik van CPB kan verminderen (hoofdstuk 3). Dit onderzoek heeft aangetoond, dat heparine voorbehandeling van het extracorporale circuit de systemische ontstekingsreacties die door CPB worden veroorzaakt, aanzienlijk reduceert en de interactie tussen witte bloedlichaampjes en het endotheel zou kunnen verminderen. Het is denkbaar dat dit beschermende effect van een heparine gecoat oppervlak niet zozeer veroorzaakt wordt door rechtstreekse interactie van de heparinelaag met de stolling of het fibrinolytisch systeem, maar meer doordat deze laag de mediatoren van de opeenvolgende ontstekingsreacties vermindert.

Onze kennis van de invloed van heparine gecoate extracorporale circuits op systemische ontstekingsreacties en activeringspatronen van trombine generatie c.q. remming en het fibrinolytisch systeem zoals besproken in hoofdstuk 2 en 3, gaven aanleiding om de intrinsieke trombogeniciteit van het extracorporale circuit gedetailleerder te bestuderen. We bemerkten dat voor het bereiken van een klinisch voordeel van heparine voorbehandelde extracorporale systemen verschillende aanpassingen nodig zijn van de wijze waarop CPB wordt uitgevoerd. Hiertoe hebben we een dierexperimenteel onderzoek uitgevoerd met het doel meer licht te werpen op de intrinsieke trombogeniciteit van extracorporale circuits. Tevens is het voordeel van heparine voorbehandelde circuits in een extracorporaal levensondersteunend systeem zonder volledige systemische heparinisatie en met minimale interferentie van de zogenaamde materiaal onafhankelijke stimuli onderzocht (hoofdstuk 4). De resultaten van deze dierexperimentele studie toonden aan dat oppervlaktemodificatie met heparine, een tromboresistent effect heeft en derhalve het gebruik van systemische heparine in een heparine gecoat extracorporaal systeem kan verminderen. Bovendien bleek de bepaling van fibrinopeptide A een waardevolle test om de stollingsactiviteit in een extracorporaal systeem in kaart te kunnen brengen. 
Aangezien CPB nog steeds met een geïnduceerd hemostatisch defect geassocieerd wordt, waarbij dysfunctie van bloedplaatjes een belangrijke rol lijkt te spelen, werd een klinische studie opgezet om te onderzoeken of de potentiële procoagulante activiteit van bloedplaatjes, gedetecteerd als annexine V-binding, veranderde tijdens electieve coronaire bypass operaties. Hierbij werd de annexine V-binding zowel in een onbehandeld als in een heparine voorbehandeld extracorporaal systeem onderzocht (hoofdstuk 5). De waarnemingen uit dit onderzoek stemden overeen met het idee dat tijdens CPB, los van het al dan niet aanwezig zijn van een heparine oppervlaktemodificatie, bloedplaatjes gedeeltelijk geactiveerd worden om vervolgens snel aan de bloedcirculatie onttrokken te worden.

Naast materiaal afhankelijke bloedactivatie, treedt er tijdens CPB ook materiaal onafhankelijke activatie op. Recente onderzoeken hebben aangetoond dat een bijdrage aan de bloedactivatie gevormd wordt door factoren onafhankelijk van het materiaal van het extracorporale circuit, waaronder de operatiewond zelf, van veel grotere betekenis kan zijn dan tot nu toe werd aangenomen. Onvolledige lokale heparinisatie en retransfusie van procoagulante bloedceldeeltjes werden gezien als belangrijke bronnen van deze materiaal onafhankelijke activatie bij patiënten tijdens CPB. Om meer inzicht te krijgen in de gevolgen van retransfusie van bloed welke uit de borstholten was opgezogen, werd een klinische studie uitgevoerd met scheiding van dit bloed door het aanvankelijk niet met het overige bloed van de patiënt te vermengen. Hierbij werd de invloed op systemische trombine generatie, gestimuleerd door weefsel factor, onderzocht (hoofdstuk 6). In deze studie werd bewezen dat het bloed uit pericard- en pleuraholte zeer trombotisch is en retransfusie van dit bloed daardoor kan leiden tot verdere trombine generatie tijdens het gebruik van CPB. Dit zou dan deels de verhoogde bloedingsneiging in de eerste uren na hartchirurgie met gebruikmaking van $\mathrm{CPB}$ kunnen verklaren.

Onze resultaten met betrekking tot studies in relatie tot bloedactivatie tijdens $\mathrm{CPB}$ in beschouwing nemend, concluderen we dat rekening gehouden dient te worden met diverse factoren die naast het gebruik van $\mathrm{CPB}$ een gevolg zijn van de chirurgie op zich. Bloedactivatie tijdens het gebruik van CPB blijkt meerdere oorzaken te hebben, hetgeen zich manifesteert in systemische ontstekingsreacties en bloedingscomplicaties. Bij routine hartoperaties zijn deze complicaties veelal van tijdelijke aard en leiden in de regel niet tot langdurige ziekenhuisopname of blijvende gezondheidsklachten. Echter, tegenwoordig ontstaat als gevolg van een verschuiving in de patiëntenpopulatie ook een verschuiving van routine operaties naar operaties op ouderen (ouder dan 80 jaar), operaties op zeer jonge patiënten, operaties op patiënten met reeds slecht functionerende organen, re-operaties en 
spoedgevallen. Om deze reden dient onze kennis van de reacties van bloed op verschillende biomaterialen te worden uitgebreid, zodat hemocompatibele materialen kunnen worden toegepast. Een betere hemocompatibiliteit van het materiaal dat in aanraking komt met bloed is dus belangrijk, maar de voordelen van oppervlakte modificatie van deze materialen zouden nog meer voordeel op kunnen leveren, wanneer een actieve eliminatie van activatoren van andere oorsprong, zoals het operatiewondgebied, mogelijk is. Derhalve is verder onderzoek nodig naar de verbetering van de hemocompatibiliteit van het extracorporale circuit en de invloed van andere factoren, met als doel een sneller en ongecompliceerd postoperatief herstel van patiënten die een hartoperatie hebben ondergaan mogelijk te maken. 


\section{CHAPTER 10}

\section{References}

1. Gibbon JH Jr. Application of a mechanical heart and lung apparatus to cardiac surgery. Minn Med 1954;37:171.

2. Parsonnet $\mathrm{V}$, Dean $\mathrm{D}$, Bernstein $\mathrm{AD}$. A method of uniform stratification of risk for evaluating the results of surgery in acquired adult heart disease. Circulation 1989;79(suppl I):I3-I12.

3. He GW, Acuff TE, Ryan WH, Bouman RT, Douthit MB, Marck MJ. Determinants of operative mortality in elderly patients undergoing coronary artery bypass grafting. Emphasis on the influence of internal mammary grafting on mortality and morbidity. J Thorac Cardiovasc Surg 1994;108:73-81.

4. Chenoweth DE, Cooper SW, Hugli TE, Stewart RW, Blackstone EH, Kirklin JW. Complement activation during cardiopulmonary bypass: evidence for generation of $\mathrm{C} 3 \mathrm{a}$ and $\mathrm{C} 5 \mathrm{a}$ anaphylatoxins. N Engl J Med 1981;304:497-503.

5. Chenoweth DE. Complement activation produced by biomaterials. Trans Am Soc Artif Intern Organs 1986;32:226-232.

6. Courtney JM, Sundaram S, Lamba NMK, Forbes CD. Monitoring of the blood response in blood purification. Artif Organs 1993;17:260-266.

7. Edmunds LH Jr. Blood-surface interactions during cardiopulmonary bypass. J Card Surg 1993;8:404-410.

8. Royston D. Blood cell activation. Semin Thorac Cardiovasc Surg 1990;2:341-357.

9. Levy JH, Kelly AB. Inflammation and cardiopulmonary bypass. Can J Anaesth 1993;40:1009-1015.

10. Gu YJ, van Oeveren W, Boonstra PW, de Haan J, Wildevuur CRH. Leukocyte activation with increased expression of CR3 receptors during cardiopulmonary bypass. Ann Thorac Surg 1992;53:839-843.

11. Weerwind PW, Reutelingsperger CPM, Lindhout T, Hamulyák K, Schauwaert A, de Jong DS, et al. Clinical evaluation of Duraflo II heparin-treated extracorporeal circuits on the activation of the kinin and coagulation system. Proc Am Acad Cardiovasc Perfusion 1994;15:62-69.

12. Kirschfink M, Kovacs B, Mottaghy K. Extracorporeal circulation: in vivo and in vitro analysis of complement activation by heparin-bonded surfaces. Circ Shock 1993;40:221-226.

13. Brash JL, Ten Hove P. Transient adsorption of fibrinogen on foreign surfaces: Similar behaviour in plasma and whole blood. J Biomed Mater Res 1989;23:157-169.

14. Chuang HYK, King WF, Mason RG. Interaction of plasma proteins with artificial surfaces: Protein adsorption isotherms. J Lab Clin Med 1978;92:483-496.

15. Uniyal S, Brash JL. Patterns of adsorption of proteins from human plasma onto foreign surfaces. Thromb Haemost 1982;47:285-290.

16. Ihlenfield JV, Cooper SL. Transient in vivo proteins adsorption onto polymeric biomaterials. J Biomed Mater Res 1979;13:577-591. 
17. Vroman L, Adams AL, Fischer GC, Munoz PC. Interaction of high molecular weight kininogen, factor XII and fibrinogen in plasma at interfaces. Blood 1980;55:156-159.

18. Colman RW, Scott CF, Schmaier AH, Wachtfogel YT, Pixley RA, Edmunds LH. Initiation of blood coagulation at artificial surfaces, in blood in contact with natural and artificial surfaces. Leonard EF, Turitto V, Vroman L (eds). Ann New York Acad Sci 1987:253-267.

19. Heimark RL, Kurachi K, Fujikawa K, Davie EW. Surface activation of blood coagulation, fibrinolysis and kinin formation. Nature 1980;286:456-460.

20. Horbett TA, Counts RB. Von Willebrand factor/factor VIII adsorption to surfaces from human plasma. Thromb Res 1984;36:599-608.

21. Young BR, Lambrecht LK, Cooper SL, Mosher DF. Plasma proteins: Their role in initiating platelet and fibrin deposition on biomaterials. Am Chem Soc Adv Chem 1982;199:317-350.

22. Elam JH, Nygren H. Adsorption of coagulation proteins from whole blood onto polymer materials: relation to platelet activation. Biomaterials 1992;13:3-8.

23. Verrier ED, Boyle EM. Endothelial cell injury in cardiovascular surgery. Ann Thorac Surg 1996;62:915-922.

24. Boisclair MD, Lane DA, Philippou H, Sheikh S, Hunt B. Thrombin production, inactivation and expression during open heart surgery measured by assays for activation fragments including a new ELISA for prothrombin fragment $F_{1+2}$. Thromb Haemost 1993;70:253-258.

25. Gravlee GP, Haddon WS, Rothberger HK, Mills SA, Rogers AT, Bean VE, et al. Heparin dosing and monitoring for cardiopulmonary bypass. J Thorac Cardiovasc Surg 1990;99:518-527.

26. Tanaka T, Takao M, Yada I, Yuasa H, Kusagawa M, Deguchi K. Alterations in coagulation and fibrinolysis associated with cardiopulmonary bypass during open heart surgery. $J$ Cardiothorac Anaesth 1989;3:181-188.

27. Chong BH, Fawaz I, Cherterman CW, Brent MC. Heparin-induced thrombocytopenia: mechanism of interaction of the heparin-dependent antibody with platelets. $\mathrm{Br} J$ Haematol 1989;73:235-240.

28. Bindslev L, Eklund J, Norlander O, Swedenborg J, Olsson P, Nilsson E, et al. Treatment of acute respiratory failure by extracorporeal carbon dioxide elimination performed with a surface heparinized artificial lung. Anesthesiology 1987;67:117-120.

29. Toomasian JM, Hsu L, Hirschl RB, Heiss KF, Hultquist KA, Bartlett RH. Evaluation of Duraflo II heparin coating in prolonged ECMO. ASAIO Trans 1988;34:410-414.

30. Bindslev L. Adult ECMO performed with surface-heparinized equipment. ASAIO Trans 1988;34:1009-1013.

31. Mottaghy K, Oedekoven B, Schaich-Lester D, Pöppel K, Küpper W. Application of surfaces with end-point attached heparin to extracorporeal circulation with membrane lungs. ASAIO Trans 1989;35:146-152.

32. Mottaghy K, Oedekoven B, Pöppel K, Bruchmuller K, Kovacs B, Spahn A, et al. Heparin free long-term extracorporeal circulation using bioactive surfaces. ASAIO Trans 1989;35:635-637.

33. Webb AR, Mythen MG, Jacobson D, Mackie IJ. Maintaining blood flow in the extracorporeal circuit: haemostasis and anticoagulation. Intensive Care Med 1995;21:84-93.

34. Mottaghy K, Oedekoven B, Pöppel K, Kovacs B, Kirschfink M, Bruchmuller K, et al. Heparin-coated versus non-coated surfaces for extracorporeal circulation. Int J Artif Organs 1991;14:721-728. 
35. Gu YJ, van Oeveren W, Akkerman C, Boonstra PW, Huyzen RJ, Wildevuur ChRH. Heparin coated circuits reduce the inflammatory response to cardiopulmonary bypass. Ann Thorac Surg 1993;55:917-922.

36. Redmond JM, Gillinov AM, Stuart RS, Zehr KJ, Winkelstein JA, Herskowitz A, et al. Heparin-coated bypass circuits reduce pulmonary injury. Ann Thorac Surg 1993;56:474-479.

37. Courtney JM, Lamba NMK, Sundaram S, Forbes CD. Biomaterials for blood-contacting applications. Biomaterials 1994;15:737-744.

38. Courtney JM, Sundaram S, Matata BM, Gaylor JDS, Forbes CD. Biomaterials in cardiopulmonary bypass. Perfusion 1994;9:3-10.

39. Boonstra PW, Gu YJ, Akkerman C, Haan J, Huyzen R, van Oeveren W. Heparin coating of an extracorporeal circuit partly improves haemostasis after cardiopulmonary bypass. J Thorac Cardiovasc Surg 1994;107:289-292.

40. Steinberg BM, Grossi EA, Schwartz DS, McLoughlin DE, Aguinaga M, Bizekis C, et al. Heparin bonding of bypass circuits reduces cytokine release during cardiopulmonary bypass. Ann Thorac Surg 1995;60:525-529.

41. Jansen PGM, Velthuis HT, Huybregts RAJM, Paulus R, Bulder ER, van der Spoel HI, et al. Reduced complement activation and improved postoperative performance after cardiopulmonary bypass with heparin-coated circuits. J Thorac Cardiovasc Surg 1995;110: 829-834.

42. Weerwind PW, Maessen JG, van Tits LJH, Stad RK, Fransen EJ, de Jong DS, et al. Influence of Duraflo II heparin-treated extracorporeal circuits on the systemic inflammatory response in patients having coronary bypass. J Thorac Cardiovasc Surg 1995;110:1633-1641.

43. von Segesser LK. Surface coating of cardiopulmonary bypass circuits. Perfusion 1996;11:241-245.

44. Wendel HP, Ziemer G. Coating-techniques to improve the hemocompatibility of artificial devices used for extracorporeal circulation. Eur J Cardiothorac Surg 1999;16 :342-350.

45. von Segesser LK, Schilling J, Leskosek B, Marquardt K, Turina M. Surface treatments for perfusion devices. Perfusion 1994;9:197-205.

46. Kazatchkine MD, Fearon DT, Silbert JE, Austen K. Surface-associated heparin inhibits zymosan-induced activation of the human alternative complement pathway by augmenting the regulatory action of the control proteins on particle-bound C3b. J Exp Med 1979;150:1202-1215.

47. Kazatchkine MD, Fearon DT, Metcalfe DD, Rosenberg RD, Austen K. Structural determinants of the capacity of heparin to inhibit the formation of the human amplification C3 convertase. J Clin Invest 1981;67:223-228.

48. te Velthuis H, Jansen PGM, Hack CE, Eijsman L, Wildevuur CRH. Specific complement inhibition with heparin-coated extracorporeal circuits. Ann Thorac Surg 1996;61:1153-1157.

49. Moen O, Høgasen K, Fosse E, Dregrlid E, Brockmeier V, Venge P, et al. Attenuation of changes in leukocyte surface markers and complement activation with heparin-coated cardiopulmonary bypass. Ann Thorac Surg 1997;63:105-111.

50. Øvrum E, Mollnes TE, Fosse E, Holen EA, Tangen G, Ringdal MA, et al. High and low heparin dose with heparin-coated cardiopulmonary bypass: Activation of complement and granulocytes. Ann Thorac Surg 1995;60:1755-1761. 
51. Øvrum E, Brøsstad F, Holen EA, Tangen G, Abdelnoor M. Effects on coagulation and fibrinolysis with reduced versus full systemic heparinization and heparin-coated cardiopulmonary bypass. Circulation 1995;92:2579-2584.

52. Øvrum E, Brøsstad F, Holen EA, Tangen G, Abdelnoor M, Oystese R. Complete heparin-coated (CBAS) cardiopulmonary bypass and reduced systemic heparin dose: Effects on coagulation and fibrinolysis. Eur J Cardiothorac Surg 1996;10:449-455.

53. Despotis GJ, Joist JE, Hogue Jr CW, Alsoufiev A, Joiner-Maier D, Santoro SA, et al. More effective suppression of hemostatic system activation in patients undergoing cardiac surgery by heparin dosing based on a heparin blood concentration rather than ACT. Thromb Haemost 1996;76:902-908.

54. Weiss BM, von Segesser LK, Turina MI, Seifert B, Pasch T. Peri-operative course and recovery after heparin-coated cardiopulmonary bypass: Low dose versus high dose heparin management. J Cardiothorac Vasc Anesth 1996;10:464-470.

55. Kumano H, Suehiro S, Hattori K, Shibata T, Sasaki Y, Hosono M, et al. Coagulofibrinolysis during heparin-coated cardiopulmonary bypass with reduced heparinization. Ann Thorac Surg 1999;68:1252-1256.

56. Gorman RC, Ziats NP, Rao AK, Gikakis N, Sun L, Khan MM, et al. Surface-bound heparin fails to reduce thrombin formation during clinical cardiopulmonary bypass. J Thorac Cardiovasc Surg 1996;111:1-12.

57. Ranucci M, Cirri S, Conti D, Ditta A, Boncilli A, Frigiola A, et al. Beneficial effects of Duraflo II heparin-coated circuits on postperfusion lung dysfunction. Ann Thorac Surg 1996;61:76-81.

58. Videm V, Mollnes TE, Bergh K, Fosse E, Mohr B, Hagve TA, et al. Heparin-coated cardiopulmonary bypass equipment. II Mechanism for reduced complement activation in vivo. J Thorac Cardiovasc Surg 1999;117:803-809.

59. Ranucci M, Mazzucco A, Pessotto R, Grillone G, Casati V, Porreca L, et al. Heparin-coated circuits for high risk patients: a multi-center, prospective, randomized trial. Ann Thorac Surg 1999;67:994-1000.

60. van der Linden J, Casimir-Ahn $\mathrm{H}$. When do cerebral emboli appear during open heart operations? A transcranial doppler study. Ann Thorac Surg 1991;51:237-241.

61. Weman S, Karhunen PJ, Penttilä A, Järvinen AA, Salminen US. Reperfusion injury associated with one fourth of deaths after coronary artery bypass grafting. Ann Thorac Surg 2000;70:807-812.

62. Gu YJ, Mariani MA, Boonstra PW, Grandjean JG, van Oeveren W. Complement activation in coronary artery bypass grafting patients without cardiopulmonary bypass. Chest 1999; 116:892-898.

63. Paparella D, Yau TM, Young E. Cardiopulmonary bypass induced inflammation: pathophysiology and treatment. An update. Eur J Cardiothorac Surg 2002;21:232-244.

64. Schönberger JP, Everts PAM, Hoffmann JJ. Systemic blood activation with open and closed venous reservoir. Ann Thorac Surg 1995;59:1549-1555.

65. Valeri CR, Khabbaz K, Khuri SF, Marquardt C, Ragno C, Feingold H, et al. Effects of skin temperature on platelet function in patients undergoing extracorporeal bypass. $J$ Thorac Cardiovasc Surg 1992;104:108-116.

66. Menaschè P, Peynet J, Larivier J, Tronc F, Piwinca A, Bloch G, et al. Does normothermia during cardiopulmonary bypass increase neutrophil-endothelium interactions? Circulation 1994;90(part II):II-275-II-279. 
67. Menaschè P, Peynet J, Haeffner-Cavaillon N, Carreno MP, de Chaumaray T, Dillisse V, et al. Influence of temperature on neutrophil trafficking during clinical cardiopulmonary bypass. Circulation 1995;92(Suppl II):II-334-II-340.

68. Le Deist F, Menaschè P, Kucharsky C, Bel A, Piwinca A, Bloch G. Hypothermia during cardiopulmonary bypass delays but does not prevent neutrophil-endothelial cell adhesion. A clinical study. Circulation 1995;92(Suppl II):II-354-II-358.

69. Kirklin JK, Chenoweth DE, Naftel DC, Blackstone EH, Kirklin JW, Bitran DD, et al. Effects of protamine administration after cardiopulmonary bypass on complement, blood elements, and the hemodynamic state. Ann Thorac Surg 1986;41:193-199.

70. Cavarocchi NC, Schaff HV, Orszulak TA, Homburger HA, Schnell WA Jr, Pluth JR. Evidence for complement activation by protamine-heparin interaction after cardiopulmonary bypass. Surgery 1985;98:525-531.

71. D'Ambra M. Restoration of the normal coagulation process: Advances in therapies to antagonize heparin. J Cardiovasc Pharmacol 1996;27(Suppl.1):S58-S62.

72. de Haan J, Boonstra PW, Monnink SH, Ebels T, van Oeveren W. Retransfusion of suctioned blood during cardiopulmonary bypass impairs hemostasis. Ann Thorac Surg 1995;59:901-907.

73. Chung JH, Gikakis N, Rao K, Drake TA, Colman RW, Edmunds LH Jr. Pericardial blood activates the extrinsic coagulation pathway during clinical cardiopulmonary bypass. Circulation 1996;93:2014-2018.

74. de Haan J, Boonstra PW, Tabuchi N, van Oeveren W, Ebels T. Retransfusion of thoracic wound blood during heart surgery obscures biocompatibility of the extracorporeal circuit. $J$ Thorac Cardiovasc Surg 1996;111:272-275.

75. Philippou H, Davidson SJ, Mole T, Pepper JR, Burman JF, Lane DA. Two-chain factor VIIa generated in the pericardium during surgery with cardiopulmonary bypass: relationship to increased thrombin generation and heparin concentration. Arterioscler Thromb Vasc Biol 1999; 19:248-254.

76. Aldea GS, Soltow LO, Chandler WL, Triggs CM, Vocelka CR, Crockett GI, et al. Limitation of thrombin generation, platelet activation, and inflammation by elimination of cardiotomy suction in patients undergoing coronary artery bypass grafting treated with heparin-bonded circuits. J Thorac Cardiovasc Surg 2002;123:742-755.

77. De Somer F, Van Belleghem Y, Caes F, François K, Van Overbeke H, Arnout J, et al. Tissue factor as the main activator of the coagulation system during cardiopulmonary bypass. J Thorac Cardiovasc Surg 2002;123:951-958.

78. Woodman RC, Harker LA. Bleeding complications associated with cardiopulmonary bypass. Blood 1990;76:1680-1697.

79. Tabuchi N, de Haan J, Boonstra PW, van Oeveren W. Activation of fibrinolysis in the pericardial cavity during cardiopulmonary bypass. J Thorac Cardiovasc Surg 1993;106: 828-833.

80. Brooker RF, Brown WR, Moody DM, Hammon JW, Reboussin DM, Deal DD, et al. Cardiotomy suction: A major source of brain lipid emboli during cardiopulmonary bypass. Ann Thorac Surg 1998;65:1651-1655.

81. Nieuwland R, Berckmans RJ, Rotteveel-Eijkman RC, Maquelin KN, Roozendaal KJ, Jansen PGM, et al. Cell-derived microparticles generated in patients during cardiopulmonary bypass are highly procoagulant. Circulation 1997;96:3534-3541. 
82. Boisclair MD, Lane DA, Philippou H, Esnouf MP, Sheikh S, Hunt B, et al. Mechanisms of thrombin generation during surgery and cardiopulmonary bypass. Blood 1993;82:3350-3357.

83. Borowiec JW, Bozdayi M, Jaramillo A, Nilsson L, Venge P, Henze A. Influence of two blood conservation techniques (cardiotomy reservoir versus cell saver) on biocompatibility of heparin coated cardiopulmonary bypass during coronary revascularization surgery. J Card Surg 1997;12:190-197.

84. Reents W, Babin-Ebell J, Misoph MR, Schwarzkopf A, Elert O. Influence of different autotransfusion devices on the quality of salvaged blood. Ann Thorac Surg 1999;68:58-62.

85. Phillippou H, Adami A, Davidson SJ, Pepper SJ, Burman JF, Lane DA. Tissue factor is rapidly elevated in plasma collected from the pericardial cavity during cardiopulmonary bypass. Thromb Haemost 2000;84:124-128.

86. Andersen RE, Hansson LO, Liska J, Settergren G, Vaage J. The effect of cardiotomy suction on brain injury markers and $\mathrm{S} 100 \beta$ after cardiopulmonary bypass. Ann Thorac Surg 2000; 69:847-850.

87. Johnsson P, Blomquist S, Luhrs C, Malmkvist G, Alling C, Solem J, et al. Neuron-specific enolase increase in plasma during and immediately after extracorporeal circulation. Ann Thorac Surg 2000;69:750-754.

88. Lavee J, Naveh N, Dinbar I, Shinfield A, Goor DA. Prostacycline and prostagladin $\mathrm{E}_{2}$ mediate reduction of increased mean arterial pressure during cardiopulmonary bypass by aspiration of shed pulmonary venous blood. J Thorac Cardiovase Surg 1990;100:546-551.

89. Walpoth BH, Eggensperger N, Hauser SP, Neidhart P, Kurt G, Spaeth PJ, et al. Effects of unprocessed and processed cardiopulmonary bypass blood retransfused into patients after cardiac surgery. Int J Artif Organs $1999 ; 22: 210-216$.

90. Morris KN, Kinross FM, Stirling GR. Hemolysis of blood in the pericardium: the major source of plasma hemoglobin during total body perfusion. J Thorac Cardiovasc Surg 1965;49: 250-258.

91. Hansbro SD, Sharpe DAC, Catchpole R, Welsh KR, Munsch CM, McGoldrick JP, et al. Hemolysis during cardiopulmonary bypass : an in vivo comparison of standard roller pumps, nonocclusive roller pumps and centrifugal pumps. Perfusion 1999;14:3-10.

92. Gott VL, Whiffen JD, Datten RC. Heparin bonding on colloidal graphite surfaces. Science 1963;142:1297-1298.

93. Pasche B, Kodama K, Larm O, Olsson P, Swedenborg J. Thrombin inactivation on surfaces with covalently bonded heparin. Thromb Res 1986;44:739-748.

94. von Segesser LK, Weis BM, Garcia E, Gallino A, Turina M. Reduced blood loss and transfusion requirements with low systemic heparinization: preliminary clinical results in coronary artery revascularization. Eur J Cardio-thorac Surg 1990;4:639-643.

95. Kodama K, Pasche B, Olsson P, Swedenborg J, Adolfsson L, Larm O, et al. Antithrombin III binding to surface immobilized heparin and its relation to $\mathrm{F} \mathrm{X}_{\mathrm{a}}$ inhibition. Thromb Haemost 1987;58:1064-1067.

96. Arnander C, Dryjski M, Larsson R, Olsson P, Swedenborg J. Thrombin uptake and inhibition on endothelium and surface with a stable heparin coating. A comparative in vitro study. J Biomed Mater Res 1986;20:235-246.

97. Bagge L, Thelin S, Hultman J, Nilsson L, Thorelius J, Hillstrom PA. Heparin/protamine doses influence benefits related to heparin-coated CPB-sets in pigs. Abstract-book: The Scandinavia Association of Cardiovascular and Thoracic surgery. Helsinki, Findland, august 1-3, 1988:22. 
98. Nilsson L, Storm KE, Thelin S, Bagge L, Hultman J, Thorelius J, et al. Heparin-coated equipment reduces complement activation during cardiopulmonary bypass in the pig. Artif Organs 1990;14:46-48.

99. Pradhan MJ, Fleming JS, Nkere UU, Arnold J, Wildevuur ChRH, Taylor KM. Clinical experience with heparin-coated cardiopulmonary bypass circuits. Perfusion 1991;6:235-242.

100. Tong SD, Rolfs MR, HSu LC. Evaluation of Duraflo II heparin immobilized cardiopulmonary bypass circuits. ASAIO Trans 1990;36:M654-M656.

101. Takano H, Nakano S, Kadoba K, Kaneko M, Miyamoto Y, Ohtake S, et al. Evaluation of the biocompatibility of a new method for heparin coating of cardiopulmonary bypass circuit. ASAIO J 1992;38:M390-M394.

102. Young JA, Kisher T, Doty DB. Adequate anticoagulation during cardiopulmonary bypass determined by activated coagulation time and appearance of fibrin monomer. Ann Thorac Surg 1978;26:231-240.

103. Schwartz BS. Heparin: What is it ? How does it work ? Clin Cardiol 1990;13:112-115.

104. Hirsh J. Mechanism of action and monitoring of anticoagulants. Semin Thromb Hemost 1986;12:1-11.

105. Ofosu FA, Gray E. Mechanisms of action of heparin: applications to the development of derivatives of heparin and heparinoids with antithrombotic potential. Semin Thromb Hemost 1988;14:9-17.

106. Hynes TM, Hull R, Weg JG. Antithrombotic therapy of venous thromboembolic disease. Chest 1986;89:265-355.

107. Hogg DJ, Jackson CM. Fibrin monomer protects thrombin from inactivation by heparinantithrombin III: Implications for heparin efficacy. Proc Natl Acad Sci 1989;86:3619-3623.

108. Bar-Shavit R, Eldor A, Vlodavsky I. Binding of thrombin to subendothelial extracellular matrix. J Clin Invest 1989;84:1096-1104.

109. Okwusidi JI, Anvari N, Kulczycky M, Blajchman MA, Buchanan MR, Ofosu FA. Fibrin moderates the catalytic action of heparin but not that of dermatan sulphate on thrombin inhibition in human plasma. J Lab Clin Med 1991;117:359-364.

110. Okwusidi JI, Falcone M, Van Ryn-McKenna J, Hirsch J, Ofosu FA, Buchanan MR. In vivo catalysis of thrombin inhibition by antithrombin III or heparin cofactor II and antithrombotic effect: differential effects of unfractionated heparin and dermatan sulphate. Thromb Haemorrh Disorders 1990;1:77-80.

111. Pindur G, Koehler M, Wenzel E. Thrombin-generation inhibition in the presence of unfractionated heparin and low molecular heparin. Thromb Haemorrh Disorders 1992;5:37-41.

112. Harker L, Malpass TW, Branson HE, Hessel II EA, Slichter SA. Mechanism of an abnormal bleeding in patients undergoing cardiopulmonary bypass: Acquired transient platelet dysfunction associated with selective $\alpha$-granule release. Blood 1980;56:824-834.

113. Mammen EF, Kaerts MH, Washington BC, Walk LW, Brown JM, Burdick M, et al. Hemostasis changes during cardiopulmonary bypass surgery. Semin Thromb Hemost 1985;11:281-292.

114. Stibbe J, Kluft C, Brommer EJP, Comes M, De Jong DS, Nauta J. Enhanced fibrinolytic activity during cardiopulmonary bypass in open-heart surgery in man is caused by extrinsic (tissue-type) plasminogen activator. Eur J Clin Invest 1984;14:375-382. 
115. Lambert CJ, Marengo-Rowe AJ, Leveson JE, Green RH, Thiele JP, Geisler GF, et al. The treatment of postperfusion bleeding using epsilon-aminocaproic acid, cryoprecipitate, freshfrozen plasma, and protamine sulfate. Ann Thorac Surg 1979;28:440-444.

116. Moriau M, Masure R, Hurlet A, Dekeys C, Chalant C, Ponlet R, et al. Haemostasis disorders in open heart surgery with extracorporeal circulation. Importance of the platelet function and the heparin neutralization. Vox Sang 1977;32:41-51.

117. Gans H, Krivit W, Runyeon A, McAuley M, Gans MA. Problems in hemostasis during open-heart surgery. III. Epsilon aminocaproic acid as an inhibitor of plasminogen activator activity. Ann Surgery 1962;155:268-274.

118. Tice DA, Reed GE, Claus RH, Worth MH. Hemorrhage due to fibrinolysis occuring with open-heart operations. J Thorac Cardiovas Surg 1963;46:673-679.

119. Kevy SV, Glickman RM, Bernhard WF, Diamond LK, Gross RE: The pathogenesis and control of the hemorrhagic defect in open heart surgery. Surg Gynecol Obstet 1966;123:313318.

120. Gans H, Castaneda AR, Subramanian V, John S, Lillehei CW. Problems in hemostasis during open heart surgery: IX. Changes observed in the plasminogen-plasmin system and their significance for therapy. Ann Surg 1967;166:980-986.

121. Mammen EF. Natural proteinase inhibitors in extracorporeal circulation. Ann NY Acad Sci $1968 ; 146: 754-762$.

122. Rhodes GR, Silver D. Periepicardial fibrinolytic activity: Relation to cardiac bleeding. Surgery 1975;78:230-237.

123. Lackie JM, de Bono D. Interaction of neutrophil granulocytes and endothelium in vitro. Microvasc Res 1977;13:107-112.

124. MacGregor RR, Macarak EJ, Kefalides NA. Comparative adherence of granulocytes to endothelial monolayers and nylon fibre. J Clin Invest 1978;61:697-702.

125. Harlan JM. Leukocyte-endothelial interactions. Blood 1985;65:513-525.

126. Thomas PD, Hampson FW, Casale JM, Hunninghake GW. Neutrophil adherence to human endothelial cells. J Lab Clin Med 1988;111:286-292.

127. Bagge U, Amundsen B, Lauritzen C. White blood cell deformability and plugging of skeletal muscle capillaries in hemorrhagic shock. Acta Physiol Scand 1980;108:159-163.

128. Downey GP, Worthen GS. Neutrophil retention in model capillaries. Deformability, geometry and hydrodynamic forces. J Appl Physiol 1988;65:1861-1871.

129. Selby C, Drost E, Wraith PK, Lowe GDO, MacNee W. Neutrophil deformability in vitro determines in vivo retention in man. Am Rev Respir Dis 1990;141:A302.

130. Hoover RL, Briggs RT, Karnovsky MJ. The adhesive interaction between polymorphonuclear leukocytes and endothelial cells in vitro. Cell 1978;14:423-428.

131. Zimmerman GA, Hill HR. Inflammatory mediators stimulate granulocyte adherence to cultured human endothelial cells. Thromb Res 1984;35:203-317.

132. Patarroyo M, Makgoba MW. Leukocyte adhesion to cells in immune and inflammatory responses. Lancet 1989;2:1139-1142.

133. Anderson DC, Schmalstieg FC, Arnaout MA, Kohl S, Tosi MF, Dana N, et al. Abnormalities of polymorphonuclear leukocyte function associated with a heritable deficiency of high molecular weight surface glycoproteins (gp138): common relationship diminished cell adherence. J Clin Invest 1984;74:536-551. 
134. Springer TA, Thompson WS, Miller LJ, Schmalstieg FC, Anderson DC. Inherited deficiency of the MAC-1, LFA-1, p150,95 glycoprotein family and its molecular basis. J Exp Med 1984;160:1901-1918.

135. Zimmerman GA, McIntyre TM. Neutrophil adherence to human endothelium in vivo occurs by CDw18 (Mol, MAC-1/LFA-1/GP150,95) glycoprotein-dependent and -independent mechanisms. J Clin Invest 1988;81:531-537.

136. Cotran RS, Gimbrone MA Jr, Bevilacqua MP, Mendrick DL, Pober JS. Induction and detection of human endothelial activation antigen in vivo. J Exp Med 1986;164:661-666.

137. Bevilacque MP, Pober JS, Wheeler ME Cotran RS, Gimbrone MA Jr. Interleukin-1 acts on cultured human vascular endothelium to increase the adhesion of polymorphonuclear leukocytes, monocytes and related leukocyte cell lines. J Clin Invest 1985;76:2003-2011.

138. Marlin SD, Springer TA. Purified intercellular adhesion molecule-1 (ICAM-1) is a ligand for lymphocyte function-associated antigen 1 (LFA-1). Cell 1987;51:813-819.

139. Dustin ML, Rothlein R, Bhan AK, Dinarello CA, Springer TA. Induction by IL-1 and interferon-gamma: Tissue distribution, biochemistry, and function of a natural adherence molecule (ICAM-1). J Immunol 1986;137:245-254.

140. Stauton DE, Marlin SD, Stratowa C, Dustin ML, Springer TA. Primary structure of ICAM-1 demonstrates interaction between members of immunoglobulin and integrin supergene families. Cell 1988;52:925-933.

141. Bevilacque MP, Pober JS, Mendrick DL, Cotran RS, Gimbrone MA Jr. Identification of an inducible endothelial-leukocyte adhesion molecule. Proc Natl Acad Sci USA 1987;84:9238-9242.

142. Pober JS, Gimbrone MA, Lapierre LA, Mendrick DL, Fiers W, Rothlein R, et al. Activation of human endothelium by lymphokines: overlapping patterns of antigenic modulation by interleukin-1, tumor necrosis factor, and immune interferon. J Immunol 1986;137:1893-896.

143. Moser R, Schleiffenbaum B, Groscurth P, Fehr J. Interleukin-1 and tumor necrosis factor stimulate human vascular endothelial cells to promote transendothelial neutrophil passage. J Clin Invest 1989;83:444-455.

144. Pohlman TH, Stanness KA, Beatty PG, Ochs HD, Harlan JM. An endothelial cell surface factor(s) induced in vitro by lipopolysaccharide, interleukin-1, and tumor necrosis factor increases neutrophil adherence by CDw18-dependent mechanisms. J Immunol 1986;136: 4548-4553.

145. Heyman PW, Cho CS, McRea JC, Olson DB, Kim SW. Heparinized polyurethanes: in vitro and in vivo studies. J Biomed Mater Res 1985;19:419-436.

146. Gu YJ, van Oeveren W, van der Kamp KWHJ, Akkerman C, Boonstra PW, Wildevuur ChRH. Heparin coating of extracorporeal circuits reduces thrombin formation in patients undergoing cardiopulmonary bypass. Perfusion 1991;6:220-225.

147. Leeuwenberg JFM, Smeets EF, Neefjes JJ, Shaffer MA, Cinek T, Jeunhomme TMAA, et al. E-selectin and intercellular adhesion molecule-1 are released by activated human endothelial cells in vitro. Immunology 1992;77:543-549.

148. Leeuwenberg JFM, Jeunhomme GMMA, Buurman WA. Slow release of soluble TNF-receptors by monocytes in vitro. J Immunol 1994;152:4036-4043.

149. Dentener MA, Bazil V, Von Asmuth EJU, Ceska M, Buurman WA. Involvement of CD14 in lipopolysaccharide-induced Tumor Necrosis Factor- $\alpha$, Interleukin- 6 and Interleukin- 8 release by human monocytes and alveolar macrophages. J Immunol 1993;150:2885-2891. 
150. Bouma MG, Stad RK, van den Wildenberg FAJM, Buurman WA. Differential regulatory effects of adenosine on cytokine release by activated human monocytes. J Immunol 1994; 153:4159-4168.

151. Videm V, Nilsson L, Venge P, Svennevig JL. Reduced granulocyte activation with a heparin-coated device in an in vitro model of cardiopulmonary bypass. Artif Organs 1991;15: 90-95.

152. Kawamura T, Wakusawa R, Okada K, Inada S. Elevation of cytokines during open heart surgery with cardiopulmonary bypass: participation of IL-8 and IL-6 in reperfusion injury. Can J Anaesth 1993;40:1016-1021.

153. Finn A, Naik S, Klein N, Levinsky RJ, Strobel S, Elliott M. Interleukin-8 release and neutrophil degranulation after pediatric cardiopulmonary bypass. J Thorac Cardiovasc Surg 1993;105:234-241.

154. Strieter RM, Kunkel SL, Showell HJ, Remick DG, Phan SH, Ward PA, et al. Endothelial cell gene expression of a neutrophil chemotactic factor by TNF- $\alpha$, LPS and IL-1B. Science 1989;243:1467-1469.

155. Lantz M, Malik S, Slevin ML, Olsson I. Infusion of tumor necrosis factor (TNF) causes an increase in circulating TNF-binding protein in humans. Cytokine 1990;2:402-406.

156. Van Zee KJ, Kohno T, Fischer E, Rock CS, Moldawer LL, Lowry SF. Tumor necrosis factor soluble receptors circulate during experimental and clinical inflammation and can protect against excessive tumor necrosis factor-alfa in vitro and in vivo. Proc Natl Acad Sci USA 1992;89:4845-4849.38.

157. Spinas GA, Keller U, Brockhaus M. Release of soluble receptors for tumor necrosis factor (TNF) in relation to circulating TNF during experimental endotoxinaemia. J Clin Invest 1992;90:533-536.

158. Froon AHM, Bemelmans MHA, Greve JW, Van der Linden CJ, Buurman WA. Increased plasma levels of soluble Tumor Necrosis Factor receptors in sepsis syndrome: correlation with plasma creatinine. Crit Care Med 1994;22:803-809.

159. Van Snick J. Interleukin-6: an overview. Annu Rev Immunol 1990;8:253-278.

160. Froon AHM, Greve JW, Van der Linden CJ, Buurman WA. Increased concentrations of cytokines and adhesion molecules in patients after repair of abdominal aortic aneurysm. Eur J Surg 1996;162:287-296.

161. Gearing $\mathrm{AJH}, \mathrm{Newman} \mathrm{W}$. Circulating adhesion molecules in disease. Immunol Today 1993;10:506-512.

162. Larm O, Larsson R, Olsson P. A new non-thrombogenic surface prepared by selective covalent binding of heparin via a modified reducing terminal residue. Biomat Med Dev Art Org 1983;11:161-172.

163. Olsson P, Larm O, Larsson R, Lins E, Swedenborg J. Requirements for thromboresistance of surface-heparinized materials. Ann NY Acad Sci 1983;416:525-537.

164. Muehrcke DD, McCarthy PM, Kottke-Marchant K, Harasaki H, Pierre-Yared J, Borsh JA, et al. Biocompatibility of heparin-coated extracorporeal bypass circuits: a randomized, masked clinical trial. J Thorac Cardiovasc Surg 1996;122:472-483.

165. Bannan S, Martin PG. Thrombin generation with heparin-bonded cardiopulmonary bypass circuits. J Thorac Cardiovasc Surg 1996;112:849. 
166. Kaufmann F, Hennig E, Loebe M, Hetzer R. Improving the antithrombogenity of artificial surfaces through heparin coating - clinical experience with the pneumatic extracorporeal Berlin heart assist device. Cardiovase Engineering 1996;1:40-44.

167. Gerlach M, Föhre B, Keh D, Riess H, Falke KJ, Gerlach H. Global and extended coagulation monitoring during extracorporeal lung assist with heparin-coated systems in ARDS patients. Int J Artif Organs 1997;20:29-36.

168. von Segesser LK, Weiss BM, Pasic M, Garcia E, Turina MI. Risk and benefit of low systemic heparinization during open heart operations. Ann Thorac Surg 1994;58:391-398.

169. von Segesser LK, Weiss BM, Garcia E, von Felton A, Turina MI. Reduction and elimination of systemic heparinization during cardiopulmonary bypass. J Thorac Cardiovasc Surg 1992; 103:790-799.

170. Pekna M, Hagman L, Haldén E, Nilsson UR, Nilsson B, Thelin S. Complement activation during cardiopulmonary bypass: effects of immobilized heparin. Ann Thorac Surg 1994;58:421-424.

171. Mellbye OJ, Froland SS, Lilleaasen P, Svennevig J-L, Mollnes TE. Complement activation during cardiopulmonary bypass: comparison between the use of large volumes of plasma and dextran 70. Eur Surg Res 1988;20:101-109.

172. Bosner RS, Dave JR, Davies ET, John L, Taylor P, Gaya H, et al. Reduction of complement activation during bypass by protamine manipulation. Ann Thorac Surg 1990;69:1-4.

173. Jansen PGM, te Velthuis H, Bulder ER, Paulus R, Scheltinga MR, Eijsman L, et al. Reduction in prime volume attenuates the hyperdynamic response after cardiopulmonary bypass. Ann Thorac Surg 1995;60:544-550.

174. Tabuchi N, de Haan J, Gallandat Huet RCG, Boonstra PW, van Oeveren W. Gelatin use impairs platelet adhesion during cardiac surgery. Thromb Haemost 1995;74:1-5.

175. Collis RE, Collins PW, Gutteridge CN, Kaul A, Newland AC, Williams DM, et al. The effect of hydroxyethyl starch and other plasma volume substitutes on endothelial cell activation; an in vitro study. Intensive Care Med 1994;20:37-41.

176. Neonatal ECMO Registry Report. Ann Arbor, MI: University of Michigan Medical Center, January 1994.

177. Sell LL, Cullen ML, Whittlesey GC, Yedlin ST, Philippart AI, Bedard MP, et al. Hemorrhagic complications during extracorporeal membrane oxygenation. J Pediatr Surg 1986;21: 1087-1091.

178. Lesko SM, Mitchell AA, Epstein MF, Louik C, Giacoia GP, Shapiro S. Heparin use as a risk factor for intraventricular haemorrhage in low-birth-weight infants. N Engl J Med 1986;314: 1156-1160.

179. Inancio J, Bindslev L, Nilsson E, Gouda I, Olsson P. Extracorporeal elimination of carbon dioxide using a surface heparinized vein-to-vein bypass system. EUROXY Workshop on Design and Techniques of Extracorporeal Gas Exchange, Paris, 20-21 June 1985.

180. Edmunds LH Jr, Ellison N, Colman RW, Niewiarowski S, Rao AK, Addonizio VP, et al. Platelet function during cardiac operation: comparison of membrane and bubble oxygenators. J Thorac Cardiovasc Surg 1982;83:805-812.

181. Bick RL. Hemostasis defects associated with cardiac surgery, prosthetic devices, and other extracorporeal circuits. Semin Thromb Hemost 1985;11:249-280.

182. Harker LA. Bleeding after cardiopulmonary bypass. N Engl J Med 1986;314:1446. 
183. Wachtfogel YT, Kucich U, Greenplate J, Gluszko P, Abrams W, Weinbaum G, et al. Human neutrophil degranulation during extracorporeal circulation. Blood 1987;69:324-330.

184. Colman RW. Platelet and neutrophil activation in cardioplmonary bypass. Ann Thorac Surg 1990;49:32-34.

185. Khuri SF, Wolfe JA, Josa M, Axford TC, Szymanski I, Assousa S, et al. Hematologic changes during and after cardiopulmonary bypass and their relationship to the bleeding time and non surgical blood loss. J Thorac Cardiovasc Surg 1992;104:94-107.

186. Menichetti A, Tritapepe L, Ruvolo G, Speziale G, Cogliati A, Di Giovanni C, et al. Changes in coagulation patterns, blood loss and blood use after cardiopulmonary bypass: aprotinin vs. Tranexanic acid vs. Epsilon aminocaproic acid. J Cardiovasc Surg 1996;37:401-407.

187. Stewart GJ, Ritchie WGM, Lynch PR. Venous endothelial damage produced by massive sticking and emigration of leukocytes. Am J Pathol 1974; 74:507-532.

188. Hunt BJ, Parratt RN, Segal HC, Sheikh S, Kallis P, Yacoub M. Activation of coagulation and fibrinolysis during cardiothoracic operation. Ann Thorac Surg 1998;65:712-718.

189. Rinder CS, Bohnert J, Rinder HM, Mitchell J, Ault KA, Hillmann R. Platelet activation and aggregation during cardiopulmonary bypass. Anesthesiology 1991;75:388-393.

190. Rinder CS, Mathew JP, Rinder HM, Bonan J, Ault KA, Smith BR. Modulation of platelet surface adhesion receptors during cardiopulmonary bypass. Anesthesiology 1991;75:563-570.

191. Komai H, Haworth SG. Effect of cardiopulmonary bypass on the circulating level of soluble GMP-140. Ann Thorac Surg 1994;58:478-482.

192. Mazer CD, Hornstein A, Freedman J. Platelet activation in warm and cold heart surgery. Ann Thorac Surg 1995;59:1481-1486.

193. Ferraris VA, Rodrigues E, Ferraris SP, Huang M, Gupta A, Bennett JA, et al. Platelet aggregation abnormalities after cardiopulmonary bypass (Letter). Blood 1994; 83:299-301.

194. Boldt J, Knothe C, Welters I, Dapper FL, Hempelmann G. Normothermic versus hypothermic cardiopulmonary bypass: do changes in coagulation differ? Ann Thorac Surg 1996;62:130-135.

195. Wendel HP, Heller W, Hoffmeister HE. Pathway of platelet protection in heparin-coated devices and its significance for cardiovascular surgery. Trans Soc Biomater 1995;21:281.

196. Edmunds LH Jr. Blood platelets and bypass. J Thorac Cardiovasc Surg 1989;97:470-471.

197. Kirklin JK. Prospects for understanding and eliminating the deleterious effects of cardiopulmonary bypass. Ann Thorac Surg 1991;51:529-531.

198. Videm V, Fosse E, Mollnes TE, Ellingsen Ø, Pedersen T, Karlsen H. Different oxygenators for cardiopulmonary bypass lead to varying degrees of human complement activation in vitro. $J$ Thorac Cardiovase Surg 1989;97:764-770.

199. Schroit AJ, Madsen JW, Tanaka Y. In vivo recognition and clearance of red blood cells containing phosphatidylserine in their plasma membranes. J Biol Chem 1985;260:5131-5138.

200. Fadok VA, Voelker DR, Campbell PA, Cohen JJ, Bratton DL, Henson PM. Exposure of phosphatidylserine on the surface of apoptotic lymphocytes triggers specific recognition and removal by macrophages. J Immunol 1992;148:2207-2216.

201. Bevers EM, Comfurius P, Zwaal RFA. Changes in membrane phospholipids distribution during platelet activation. Biochim Biophys Acta 1983;736:57-66.

202. Dachary-Prigent J, Pasquet JM, Freyssinet JM, Nurden AT. Calcium involvement in aminophospholipid exposure and microparticle formation during platelet activation: a study using Ca2+-ATPase inhibitors. Biochemistry 1995;34:625-634. 
203. Kestin AS, Valeri CR, Khuri SF, Loscalzo J, Ellis PA, MacGregor H, et al. The platelet function defect of cardiopulmonary bypass. Blood 1993;82:107-117.

204. Ferroni P, Speziale G, Ruvolo G, Giovannelli A, Pulcinelli FM, Lenti L, et al. Platelet activation and cytokine production during hypothermic cardiopulmonary bypass - A possible correlation? Thromb Haemost 1998;80:58-64.

205. de Laval ME, Hill JD, Mielke CH, Macur MF, Gerbode F. Blood platelets and extracorporeal circulation. J Thorac Cardiovasc Surg 1975;69:144.

206. Hope AF, Heyns A, Lötter MG, van Reenen OR, de Kock F, Badenhorst PN, et al. Kinetics and sites of sequestration of indium 111-labeled human platelets during cardiopulmonary bypass. J Thorac Cardiovasc Surg 1981;81:880-886.

207. Lindblad B, Wakefield TW, Whitehouse WM Jr, Stanley JC. The effect of protamine sulfate on platelet function. Scan J Thorac Cardiovasc Surg 1988;22:55-59.

208. Ammar T, Fisher CF. The effects of heparinase 1 and protamine on platelet reactivity. Anesthesiology 1997;86:1382-1386.

209. Shore-Lesserson L, Ammar T, DePerio M, Vela-Cantos F, Fisher C, Sarier K. Platelet-activated clotting time does not measure platelet reactivity during cardiac surgery. Anesthesiology 1999;91:362-368.

210. Karpatkin S. Heterogenicity of human platelets. II. Functional evidence suggestive of young and old platelets. J Clin Invest 1969;47:1083-1087.

211. Björaker DG, Ketcham TR. In vivo platelet response to clinical protamine sulphate infusion [Abstract]. Anesthesiology 1982;57:A-7.

212. Mohr R, Golan M, Martinowitz U, Rosner E, Goor DA, Ramot B. Effect of cardiac operations on platelets. J Thorac Cardiovasc Surg 1986;92:434-442.

213. Kennedy PS, Solis RT, Storey SS Jr, Viancos JG, DeBakey ME. Cardiopulmonary bypass surgery. Platelet aggregation during induction of anesthesia and following heparinization of patients. Arch Surg 1978;113:1429-1432.

214. Palanzo DA, Zarro DL, Manley NJ, Montesano RM, Quinn M, Gustafson PA. Effect of surface coating on platelet count drop during cardiopulmonary bypass. Perfusion 1999;14:195-200.

215. Brister SJ, Ofosu FA, Buchanan MR. Thrombin generation during cardiac surgery: heparin the ideal anticoagulant? Thromb Haemost 1993;70:259-262.

216. Wachtfogel WT, Harpel PC, Edmunds LH Jr, Colman RW. Formation of C1,-C1-inhibitor, and plasmin- $\alpha_{2}$-plasmin inhibitor complexes during cardiopulmonary bypass. Blood 1989;73:468-471.

217. Irvine L, Sundaram S, Courtney JM, Taggart DP, Wheatley DJ, Lowe GDO. Monitoring of factor XII activity and granulocyte elastase release during cardiopulmonary bypass. ASAIO Trans 1991;37:569-571.

218. Boisclair MD, Philippou H, Lane DA. Thrombogenic mechanisms in the human: fresh insights obtained by immunodiagnostic studies of coagulation markers. Blood Coagul Fibrinolysis 1993;4:1007-1021.

219. Philippou H, Adami A, Boisclair MD, Lane DA. An ELISA for factor X activation peptide: application to the investigation of thrombogenesis in cardiopulmonary bypass. Br J Haematol 1995;90:432-437. 
220. Burman JF, Chung HI, Lane DA, Philippou H, Adami A, Lincoln JCR. Role of factor XII in thrombin generation and fibrinolysis during cardiopulmonary bypass. Lancet 1994;344: 1192-1193.

221. Korn RL, Fisher CA, Livingston ER, Stenach N, Fishman SJ, Jeevanandam V, et al. The effects of Carmeda bioactive surface on human blood components during simulated extracorporeal circulation. J Thorac Cardiovasc Surg 1996;111:1073-1084.

222. Yii M, Gourlay T, Fleming J, Matata B, Taylor KM. Evaluation of Carmeda bioactive surface (CBAS), Duraflo II and a novel nonspecific protease-modified surface using a new in vitro model simulating cardiopulmonary bypass. Perfusion 1996;11:229-240.

223. Hsu LC. Biocompatibility in cardiopulmonary bypass. J Cardiothorac Vasc Anesth 1997;11:376-382.

224. Baksaas ST, Videm V, Pedersen T, Karlsen H, Mollnes TE, Brosstad F, et al. Comparison of three oxygenator-coated and one total-circuit-coated extracorporeal devices. Perfusion 1999;14:119-127.

225. Ernofsson M, Thelin S, Siegbahn A. Thrombin generation during cardiopulmonary bypass using heparin-coated or standard circuits. Scand J Thorac Cardiovasc Surg 1995;29:157-165.

226. Wagner WR, Johnson PC, Thompson KA, Marrone GC. Heparin-coated cardiopulmonary bypass circuits: hemostatic alterations and postoperative blood loss. Ann Thorac Surg 1994; 58:734-741.

227. Salemink I, Franssen J, Willems GM, Hemker HC, Li AG, Wun TC, Lindhout T. Factor Xa cleavage of tissue factor pathway inhibitor is associated with loss of anticoagulant activity. Thromb Haemost 1998;80:273-280.

228. van 't Veer C, Golden NJ, Mann KG. Inhibition of thrombin generation by the zymogen factor VII: implications for the treatment of hemophilia A by factor VIla. Blood 2000;95:1330-1335.

229. Mann KG. Biochemistry and physiology of blood coagulation. Thromb Haemost 1999;82:165-174.

230. Maquelin KN, Nieuwland R, Lentjes EGWM, Böing AN, Mochtar B, Eijsman L, et al. Aprotinin administration in the pericardial cavity does not prevent platelet activation.J Thorac Cardiovasc Surg 2000;120:552-557.

231. van Oeveren W, Wildevuur ChRH. Blood compatibility of cardiopulmonary bypass circuits. Perfusion 1987;2:237-244.

232. van Oeveren W, Wildevuur ChRH, Kazatchkine MD. Biocompatibility of extracorporeal circuits in heart surgery. Review Transfus Sci 1990;11:5-33.

233. Arakawa M, Aoike I, Sizuki Y, Gejyo F, Terada R, Sugaya H, et al. Antithrombogenicity of polyacrylonitrile-polyethyleneoxide hollow fiber membrane developed for designing an antithrombogenic continuous ultrafiltration system. Artif Organs 1992;16:146-150.

234. Janvier G, Baquey C, Roth C, Benillan N, Bélisle S, Hardy JF. Extracorporeal circulation, hemocompatibility, and biomaterials. Ann Thorac Surg 1996;62:1926-1934.

235. Gourlay T. Biomaterial development for cardiopulmonary bypass. Perfusion 2001;16: 381-390.

236. Hall RI, Stafford-Smith M, Rocker G. The systemic inflammatory response to cardiopulmonary bypass: Pathophysiological, therapeutic, and pharmacological considerations. Anesth Analg 1997;85:766-782. 
237. Kawamura T, Inada K, Nara N, Wakusawa R, Endo S. Influence of methylprednisolone on cytokine balance during cardiac surgery. Crit Care Med 1999;27:545-548.

238. Levi M, Cromheecke ME, de Jonge E, Prins MH, de Mol BJ, Briët E, et al. Pharmacological strategies to decrease excessive blood loss in cardiac surgery: A meta-analysis of clinically relevant endpoints. Lancet 1999;354:1940-1947.

239. Defraigne JO, Pincemail J, Larbuisson R, Blaffart F, Limet R. Cytokine release and neutrophil activation are not prevented by heparin-coated circuits and aprotinin administration. Ann Thorac Surg 2000;69:1084-1091.

240. Asimakopoulos G. Systemic inflammation and cardiac surgery: An update. Perfusion 2001;16:353-360.

241. te Velthuis H, Baufreton C, Jansen PGM, Thijs CM, Hack CE, Sturk A, et al. Heparin coating of extracorporeal circuits inhibits contact activation during cardiac operations. I Thorac Cardiovasc Surg 1997;114:117-122.

242. Videm V, Mollnes TE, Fosse E, Mohr B, Bergh K, Hagve TA, et al. Heparin-coated cardiopulmonary bypass equipment. I Biocompatibility markers and development of complications in high-risk population. J Thorac Cardiovasc Surg 1999;117:794-802.

243. Wan S, LeClerc JL, Antoine M, DeSmet JM, Yim AP, Vincent JL. Heparin-coated circuits reduce myocardial injury in heart or heart-lung transplantation: A prospective, randomized trials. Ann Thorac Surg 1999;68:1230-1235.

244. Hsu LC. Heparin-coated cardiopulmonary bypass circuits: Current status. Perfusion 2001;16:417-428.

245. Kongsgaard UE, Smith-Erichsen N, Geiran O, Amundsen E, Mollnes TE, Garred P. Different activation patterns in the plasma kallikrein-kinin and complement systems during coronary bypass surgery. Acta Anaesthesiol Scand 1989;33:343-347.

246. de Smet AA, Joen MC, van Oeveren W, Roozendaal KJ, Harder MP, Eijsman L, et al. Increased anticoagulation during cardiopulmonary bypass by aprotinin. J Thorac Cardiovasc Surg 1990;100:520-527.

247. Wachtfogel YT, Kucich U, Hack CE, Gluszko P, Niewiarowski S, Colman RW, et al. Aprotinin inhibits the contact, neutrophil, and platelet activation systems during simulated extracorporeal perfusion. J Thorac Cardiovase Surg 1993;106:1-10.

248. Wachtfogel YT, Hack CE, Nuijens JH, Kettner C, Reilly TM, Knabb RM, et al. Selective kallikrein inhibitors alter human neutrophil elastase release during extracorporeal circulation. Am J Physiol 1995;268:H1352-H1357.

249. Levi M, Hack CE, de Boer JP, Brandjes DPM, Büller HR, ten Cate JW. Reduction of contact activation related fibrinolytic activity in factor XII deficient patients: Further evidence for the role of the contact system in fibrinolysis in vivo. J Clin Invest 1991;88:1155-1160.

250. Rinder C, Fitch J. Amplification of the inflammatory response: Adhesion molecules associated with platelet/white cell responses. J Cardiovasc Pharmacol 1996;27(Suppl. 1):S6-S12. 


\section{DANKWOORD}

Onderzoek doe je niet alleen. Ik heb gedurende de lange weg naar de totstandkoming van dit proefschrift medewerking en input van velen gehad. Graag zou ik een ieder waarmee ik heb samengewerkt en alle direct en indirect betrokkenen hartelijk willen danken voor de steun, kennis en support waar ik op heb mogen bouwen. Een aantal personen hebben daarbij een dusdanige rol gespeeld dat ik ze graag nog eens in het bijzonder wil bedanken.

Allereerst wil ik mijn promotor, prof. dr. Bas Mochtar, bedanken voor zijn steun en vertrouwen bij de afronding en de uiteindelijke totstandkoming van dit proefschrift.

Mijn beide co-promotors, dr. Theo Lindhout en Dick de Jong, CCP.

Theo, jouw kennis en ervaring in de onderzoekswereld van de biochemische processen hebben een onmisbare rol gespeeld in de totstandkoming van dit proefschrift. Ik ben dan ook erg blij dat je mijn co-promoter wilde zijn.

Dick, bedankt voor de vrijheid en het vertrouwen dat je mij gegeven hebt voor het opzetten, uitvoeren en analyseren van de studies. Deze hebben naast jouw expertise op het gebied van de perfusie en de kunstmatige instandhouding van de bloedcirculatie in patiënten een belangrijke rol gespeeld in mijn wetenschappelijke vorming en kennis als klinisch perfusionist.

De stafleden van de afdeling Cardio-Thoracale Chirurgie van het academisch ziekenhuis Maastricht, in het bijzonder dr. Jos Maessen en dr. Erik Fransen, bedank ik voor hun medewerking en bijdrage aan de verschillende klinische studies.

Prof. dr. O.C.K.M. Penn. Olaf, ondanks de moeilijke jaren in Maastricht heb ik mede door jouw steun een begin kunnen maken met enkele studies zoals beschreven in dit proefschrift. Ik ben je dankbaar voor de mede door jou geboden mogelijkheden, waarmee ik de basis heb kunnen leggen, welke uiteindelijk tot dit proefschrift heeft geleid.

Mijn collegae op de afdeling Extra-Corporale Circulatie van het academisch ziekenhuis Maastricht, in het bijzonder drs. Nicole Caberg. Nicole nogmaals bedankt voor jouw hulp bij de uitvoering van de verschillende studies.

Mijn collegae op de afdeling Extra-Corporale Circulatie van het Universitair Medisch Centrum Nijmegen. Indien nodig heb ik telkens een beroep op jullie 
kunnen doen. Mede door jullie support en ondanks de zo nu en dan hectische tijden heb ik me altijd naast de normale werkzaamheden bezig kunnen houden met wetenschappelijk onderzoek. Mijn dank hiervoor.

Dr. C.P.M. Reutelingsperger. Chris, bedankt voor het delen van jouw kennis op het gebied van de celbiologie, met name die van de bloedplaatjes.

Medewerkers van de verschillende laboratoria, klinische chemie, hematologie en biochemie (zowel in het academisch ziekenhuis Maastricht als op de Universiteit Maastricht), wil ik bedanken voor het analyseren van de vele bloedmonsters.

Het clusterbestuur snijdende specialismen 2 (voorzitter prof. dr. P.H.M. Spauwen) bedank ik voor de mogelijkheden die me geboden zijn om het wetenschappelijk onderzoek in Maastricht af te kunnen ronden.

De leden van de beoordelingscommissie, prof. dr. M.J.H.M. Jacobs (voorzitter), prof. dr. M.H.J. Brouwer, prof. dr. H. ten Cate, prof. dr. B.E. de Pauw en prof. dr. J. Rosing, bedank ik voor het beoordelen van het manuscript.

Captain W.G. Krause. Wolfgang bedankt voor jouw vriendschap en mentale steun tijdens het biken.

Mijn ouders. Pa en ma, jullie hebben me altijd gestimuleerd om het beste uit mezelf te halen. De basis van jullie opvoeding, het vertrouwen in mijn kunnen en onvoorwaardelijk steun zijn van grote waarde voor mij geweest. Bedankt voor al jullie zorgen!

'Last but not least' bedank ik mijn echtgenote Joke voor haar steun, betrokkenheid en luisterend oor en de kids, Kevin en Trevor, voor de leuke, gezellige momenten en jullie tomeloze energie. 


\section{Curriculum Vitae}

Patrick Weerwind is geboren op 21 november 1964 te Curaçao, Nederlandse Antillen. Na het behalen van zijn VWO-diploma in 1985, vertrok Patrick naar Nederland om in Enschede informatica te gaan studeren. Echter, na één jaar ploeteren ontdekte hij dat informatica niet de richting was waar zijn interesses lagen. Zodoende veranderde hij van studierichting en begon in 1986 met de studie klinische chemie aan de Hogeschool Enschede, waar hij in 1990 zijn getuigschrift behaalde. Zijn afstudeeronderzoek deed hij op de afdeling klinsche chemie van het Bethesda ziekenhuis te Hoogeveen, onder begeleiding van dr. E.W.G.M. Pietersen. Vervolgens kreeg hij een aanstelling als klinisch perfusionist in opleiding op de afdeling Cardiopulmonale Chirurgie / Extra-Corporale Circulatie van het academisch ziekenhuis te Maastricht. De afdeling stond onder leiding van prof.dr. O.C.K.M. Penn en dhr. D.S. de Jong, CCP (opleider). In 1993 ronde Patrick de opleiding van klinisch perfusionist af en werd geregistreerd als erkend klinisch perfusionist. Zijn onderzoek op het gebied van de hemocompatibiliteit rondom cardiopulomonale bypass, binnen de afdeling Extra-Corporale Circulatie van het academisch ziekenhuis Maastricht, mocht hij nadat hij in 1995 een aanstelling kreeg als staf klinisch perfusionist op de afdeling Extra-Corporale Circulatie van het Universitair Medisch Centrum St. Radboud te Nijmegen (hoofd dhr. G.J. Bax), voortzetten. In juni 1995 werd een deel van zijn onderzoek bekroond met de "Best Paper Award" tijdens de "Sixth European Congress on Extra-Corporeal Circulation Technology" te Waterloo, België. Sinds september 1996 is hij werkzaam als hoofd van de afdeling Extra-Corporale Circulatie van het Universitair Medisch Centrum St. Radboud.

Patrick is getrouwd met Joke Wilps en samen hebben ze twee zonen met de naam Kevin en Trevor. 

